$$
\text { كلية الدراسات الإسلامية والعربية }
$$

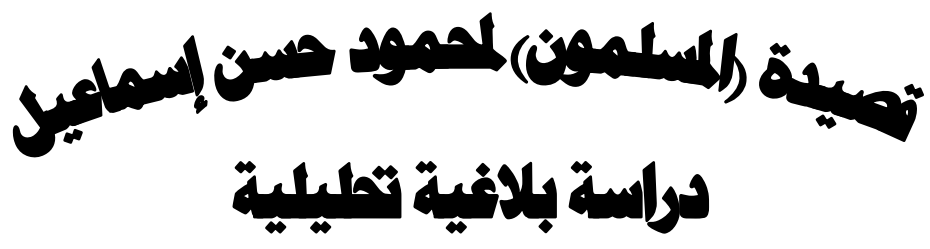

$$
\text { إعـداد }
$$

د/ عبد العريز أبو العزم عبد المقصود سليم

$$
\text { مكر مسر البـاعة والنقةد }
$$

$$
\text { فر كلبة الدراسات الإسبامية والعربية }
$$


 \\ تقلديم \\ بسم الله الرحمن الرحيم}

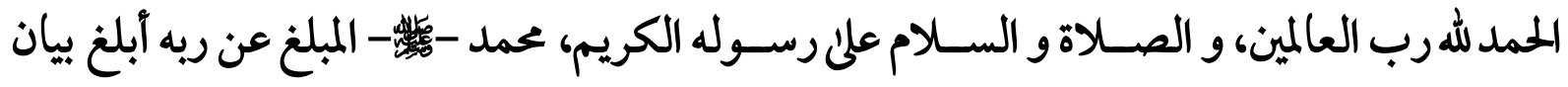

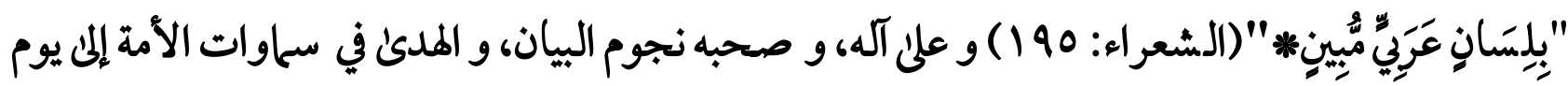

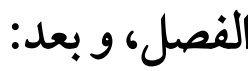

فإن شعر العرب هو ديوان معارفهم، و حصن مناقبهم، من ثم كانت درا سته، و تحليل جوانب بلاغته، و مذاهبهم في بناء مفرداته، و جمله، و مقاطعه، و طراثقهم في التخييل، و التصوير، و غيره واجباً دينياً على من يمتلك أدواته، فحسن ذلك من الإييان، لأنه " لا يكون حسن إيـان علم)، والتزاما، إلا من هسن علم، وفقه بيان القرآن، ولن يكون حسن علم، وفقه بيان القرآن الكريم إلا من حسن قراءة الششعر العربئ قراءة عربية (')." ماجدة، لا قراءة أعجمية

لمذا المعنى، و ذاك المدف، تولدت في نفسى فكرة معالجة جوانب البلاغة في هذه القصيدة ، وقد دفعنى

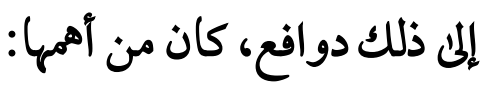
1 - أن فكرتها تصور شعوراً صادقاً بهموم العرب و المسلمين، خاصة عقب حرب فلسطين سنة 19 ام

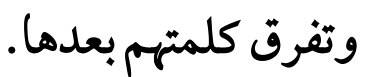

Y- : أن بناءها - شكلا ومضمونا - قد نسج نسجا محكما، فمن حيث الشكل تراه قد اعتمد أسلوب الاستفهام في مطلعها، و خاتمتها، كماصـيغت في آربعة مقاطع، ختم كل منها بأسـلوب اسـتفهام يلائم مضــمون المقطع، ويمهد للذئ يليه، فيا يعرف بلاغيا بـ (رد الخاتمة على المطلع). ومن حيث المضــمون ترىئ في طياتها خيطا نفسـيا يوثق الصـلة بين مقاطعها، من مطلعها إلى ختامها، يسـاعده خيال وثاب لشـاعر تمكن من أدواته الفنية، و التعبيرية، وظف فيها مفردات اللغة، وأدوات الربط، وأ ساليب البلاغة، وصور البيان ببراعة فنية، ودقة في التعبير، وجدة في التصوير، فكان موفقا-إلى حد كبير - 
في تصسوير وعيه بهموم أمته، متحسرـا علئ واقعها، مستنفرا شـعوبها للخروج من كبوتهم بمحاربة الفسـاد، والعمل الجاد المثمر.

ץ- : أن القصيدة لميتعرض لما الدار سون بدرا سة تبرز جوانب البلاغة فيها - على الرغم من غزارتها - وأثرها في طبيعة التصوير لدى الشاعر، و ملائمة ذلك للسياق، والمقام، ودورها في تشكيل معانيها الفرعية، وأدوات الربط، ودورها في تناسـب المعانى، وإحكام النسـج، إلى غير ذلك من وجوه البلاغة..، وربيا

يرجع ذلك إلى أن القصيدة لم ترد ضمن الأعال الكاملة للشاعر(')

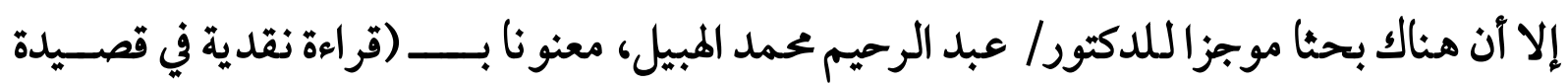
(المسلمون) للشاعر محمود حسن إسماعيل) لميتعرض للجوانب البلاغية فيها، و انصب على شكل القصيدة في بنائها على مقاطع أربعة، بين كل منها لازمة فنية بأ سلوب الاستفهام الإنكارئ، و أشار إلى ظاهرة التكرار، و إلى اعتماد الشاعر في القصيدة على عنصر الزمن، ليبرز التضاد بين الماضى والحاضر، مما يخدم هدف بحثه،.(() وهذا البحث- على أهميته- لا يهدف إلى ما قصــدت إليه من بيان وجوه البلاغة، وأثرها في تشـكيل معانى القصيدة، وطريقة التصوير فيها، و التي تجلت في درا ستى لما في مقدمة، و تهيد، و خمسة مباحث، و خاتمة، المقدمة: و قد عر ضت فيها هدف الدرا سة، و الملاحظات التي لفتت انتباهي لدرا سة جوانب البلاغة في القصيدة، أما التمهيد: فخصحصته للحديث عن حياة محمود هسن إسماعيل، و مكانته الأدبية، و آثر بيئة القرية في تكوين ملامح فكره، و شاعريته، و نتاجه الشعرى،، و مناسبة القصيدة.

المبحث الأول: و تناولت فيه البناء الفنى للقصيدة من حيث الشكل، و من حيث المضمون، أما الشكل فقدصيغت في أربعة مقاطع، متبوع كل منها بأسلوبئ استفهام، أولما يستشف منه التحسر، و ثانيها يستشف منه التعجب، والقصـيدة تردخاتمتها علئ مطلعها من خلال أسـلويلى الاسـتفهام في المطلع و الخاتمة، و كذلك فيك بنيت مقاطعها الأربعة على هذا النسـق، أما المضـمون فهو يعالج وصـفالحال العرب، والمسـلمين بعد حرب 
19 أم و المستعمر يسومهم ألوانا من العذاب، و هم لا يقوون علئ رد عدوانه، فمضمونها التحسر علئ ما وصلوا إليه، و التعجب من ثباتهم على تلك الحال.

المبحث الثانيل: و يعالج جوانب البلاغة في المقطع الأول من القصيدة، و كان تحت عنوان: وصف حال المسلمين بين التخبط، و ال ضياع. المبحث الثالث: و يعالج جوانب البلاغة في المقطع الثانى من القصيدة، و جاء تحت عنوان: التعجب من حال المسـلمين، و في يمينهم القرآن الكريم. المبحث الرابع: و يعالج جوانب البلاغة في المقطع الثالث من القصيدة، و جاء تحت عنوان: موقف الشاعر من حال أمته. المبحث الخامس: و يعالج جوانب البلاغة في المقطع الرابع من القصـيدة، و جاء تحت عنوان: بين الدعوة إلى محاربة الفسـاد، و العمل المثمر . الخاتمة: و ضمنتها أهم النتائج التي توصل إليها البحث. 
هو: محمود مسن إسهاعيل، شاعر مطبوع، متمكن ولد في / / / • / 191م في قرية النخيلة- أبو تيجأسيوط- القابعة على ضفة النيل في صعيد مصر، من أسرة فقيرة، كانت تعانى قسوة العيش، تلقى تعليمه في بلده إلى أن انتقل إلى القاهرة ليلتحق بكلية دار العلوم، ويتخرج فيها عام VIه ام وفي دار العلوم تفتحت مواهبه، وصـدر ديو انه الأول (أغانى الكوخ) الذئ تغنى فيه بمصر-ه، نهرا وحقلا، وإنسـانا، وعمل بالإذاعة المصرية منذ تخرجه، وقضئ زهرة عمره، وأنضج سنوات حياته في مراقبة البرامج الدينية بها، واختير عضوا في لجنة الشعر بالمجلس الأعلى للفنون، والآداب. وفي أواخر حياته استشعر أنه لمينل التكريم اللائق بموهبته الشعرية، ومكانته الأدبية، فسافر إلى دولة الكويت العربية، وعمل خبيراللغة العربية بمركز بحوث المناهج بوزارة التربية والتعليم، التي ظل بها إلى أن توفي في سنة 9 ام عن عمر يناهز السبعين عاما(') أثر القرية يِ حياته، وِيْ تكوين شاعريته: وقد تركت نشأثه بين أحضان الطبيعة، والنيل أثرا كبيرا في تعليمه، وفي تكوين شخصيته، فنراه يجيا بين الطبيعة يأسى لكدح الفلاحين البؤساء، فيقول:

"نشأت في قرية صغيرة في أعاق الصعيد اسمها (النخيلة) و لما من اسمها نصيب، فيكثر فيها النخيل، و البسـاتين المطلة على حافة نهر النيل من الجانب الغربي، ولمآولد في بيت علم، و لمأواجه في طفولتي مكتبة تشكل ثقافة مبكرة تعين على أي معرفة، و أول ما سمعت من اللغة العربية لغة القرآن، و قد حفظته في سن التا سعة، و أول ما سمعت من الشعر الأنغام الجنائزية التي كان يتصايح بها المنشدون أمام النعوش، و كنت أ ضيق بها، و أفزع منها، و لمذا هربت إلى معيشة كاملة في الحقل، حيث سمعت من أنغام الطبيعة لغة الطيور التي كانت أول إيقاع مو سيقي لمتدخل فيه صنعة الإنسان، يحرك نفسي إلى الإصغاءلعالم الطبيعة، بكل ما

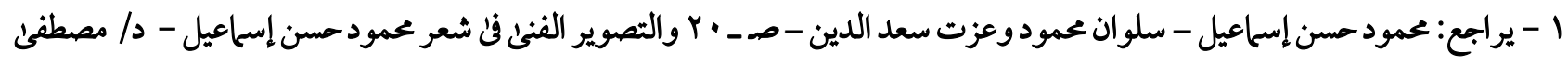

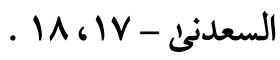


فيه، حتى الجذوع الصامتة، و الليل الأخرس، و الوجوه المستعبدة البكاء التي تتحرك حولي تحت وطأة القهر،

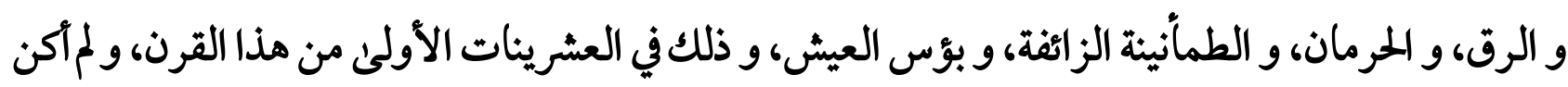

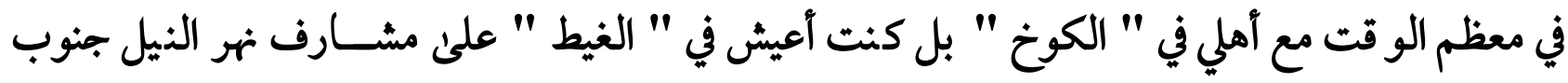

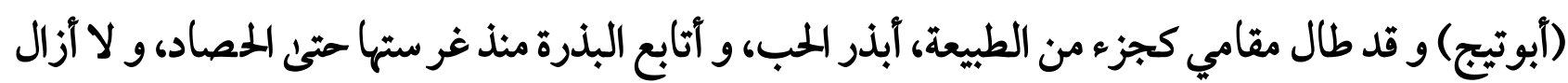
أذكر الغناء البشري الذائب من حناجر الكادهين في موا سم الزرع، و اللحصاد، و كانت كل هذه العوالمأ تبه

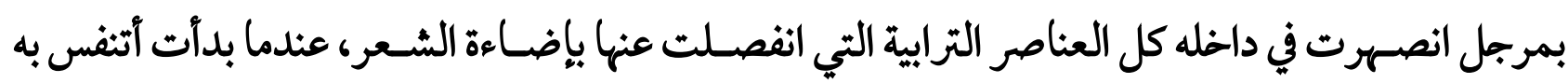
عقب فراقي لعالم القرية، و الطبيعة، إلى عالم المدينة"(() كما كان لحياة القرية، ومغانيها، دور كبي في إثراء موهبته الثـعرية، وتأملاته الطويلة في الفوارق بين

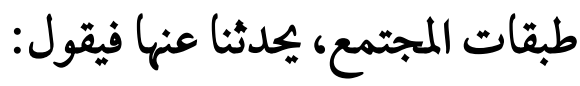
"ولم تترك طفولتي في الصعيد بصحات على حياتي كشاعر فحسب، بل كانت هي السر الذي اندلعت

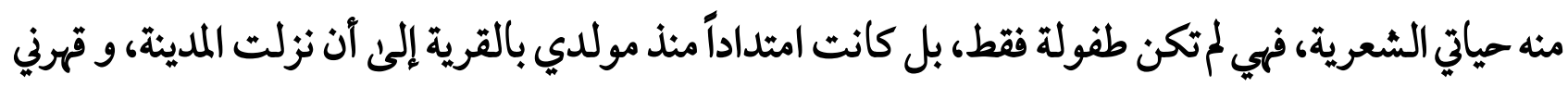

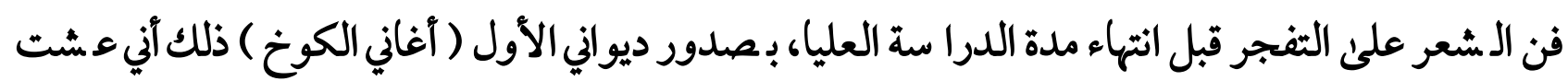
القرية بروحي، وجســدي متوغلاً في دخانها، و ترابها، و في جميع أجزائها، و رأيت الإنسـان فيها أذل من فئ

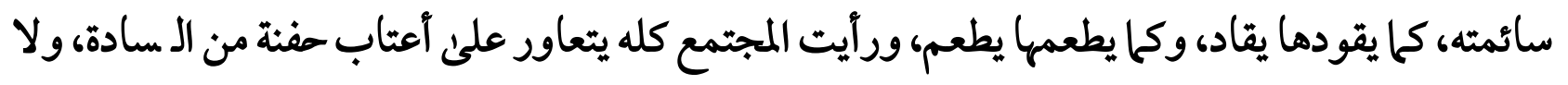
أستطيع تفسير شحنة العذاب، و القلق، و الرفض التي كنت أحملها كما فسرتها (أنغام الكوخ) و(هكذا أغني) و (أين المفر) و سائر الدواوين، والأ شعار التي نشرت بعد ذلك، و كان ديواني الأول ( أغاني الكوخ ) يمثل

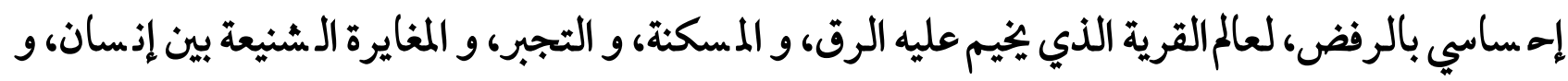

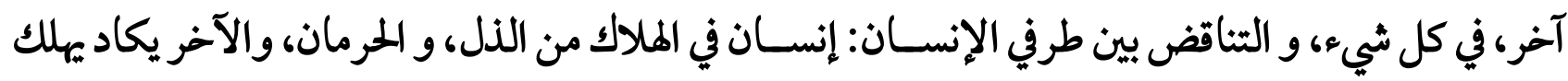

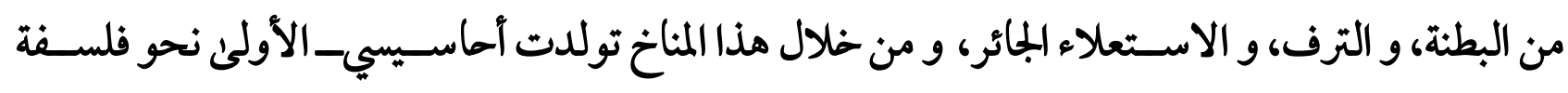

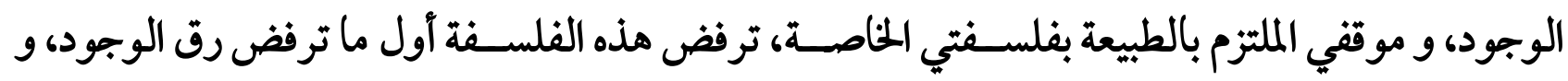

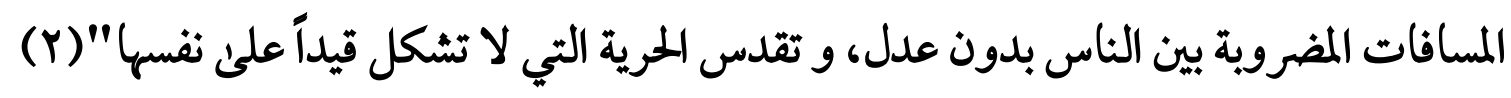

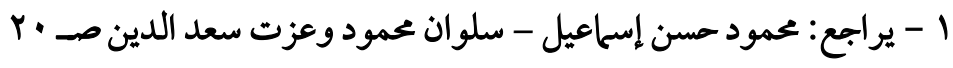

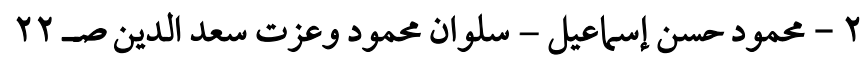


ظلت قيثارة الشاعر تتغنى بالريف مصورة حياة فلاحيه، تبرز معانتهم وتعالج مآسيهم، كحا تبرز قضايا الأمة الإ سلامية، وتصور فظائع مار ضخ المسلمون تحته من نيران ظلم المستعمر، والإقطاع، وأذنابها، ثم

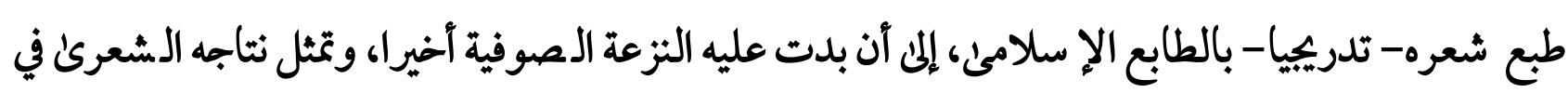

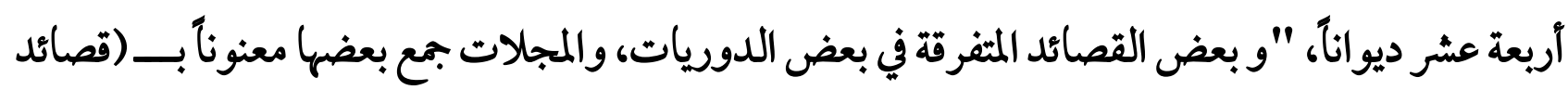

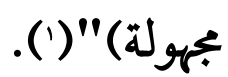

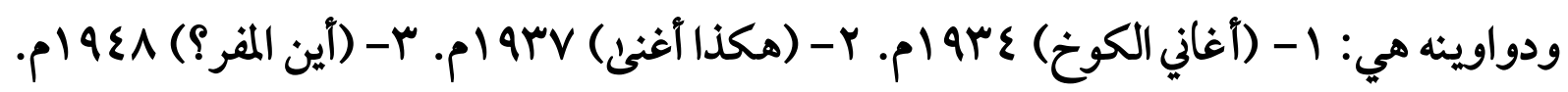

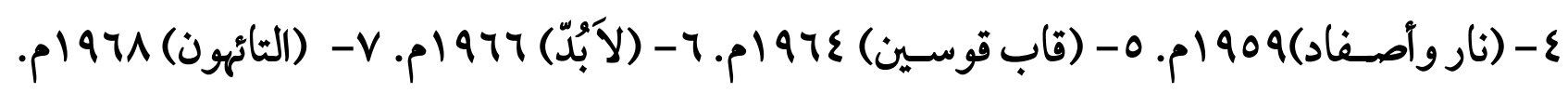

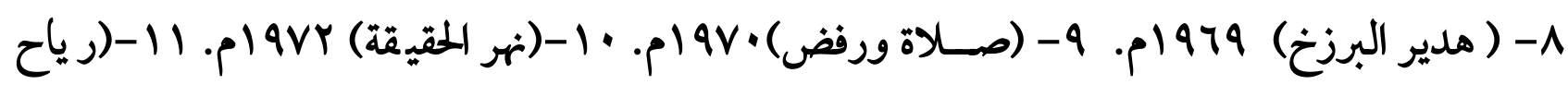
المغيب). r ا - (السـلام الذئ أعرف). وقدصــدر له ديوانان بعد وفاته، هما: با -(موسـيقى من السرـ)

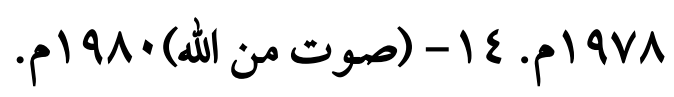
هذا، وقد طبع نتاجه كله معنونا بـــــ (الأعال الكاملة للشاعر محمود حسن إسماعيل) مرتين: الأولى: طبعة الميئة المصرية العامة للكتاب سنة ع · · rم، وهى في ثلاثة بجلدات، غير محققة، والثانية طبعة دار سعاد الصباح- القاهرة- في أربعة بجلدات سنة 7 +. - ام. (r)

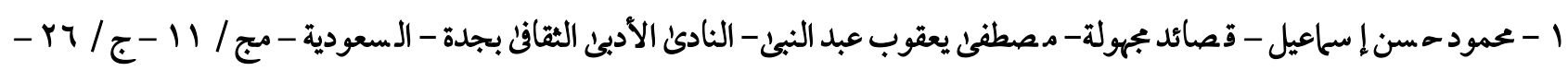

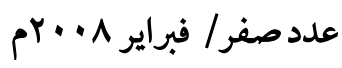

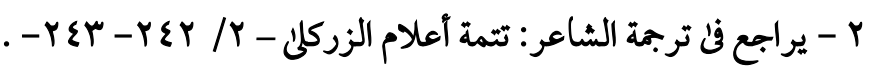




\section{نص القصيلة}

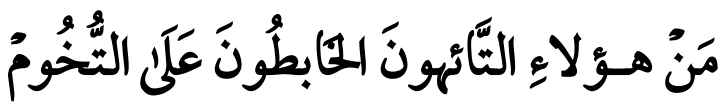

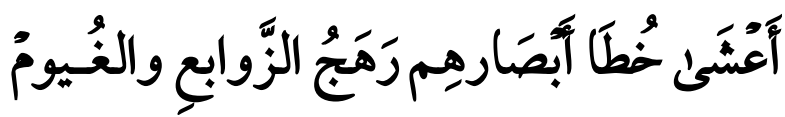

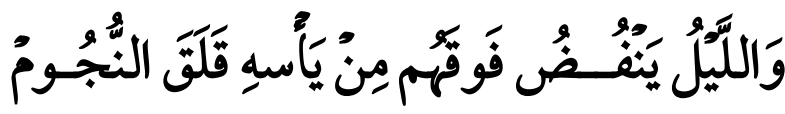

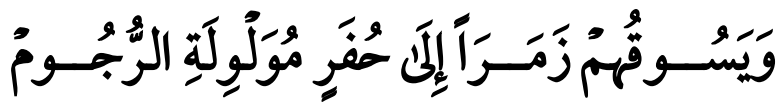

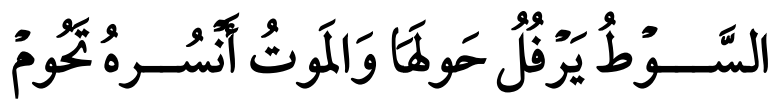

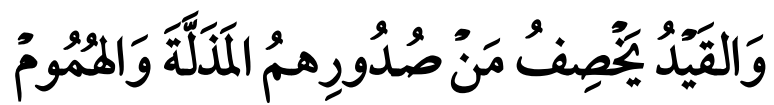

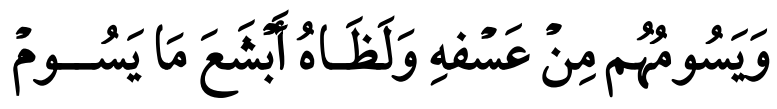

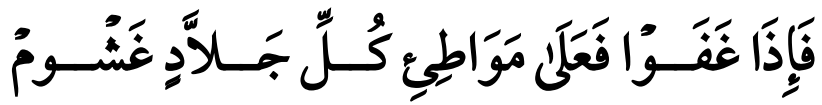

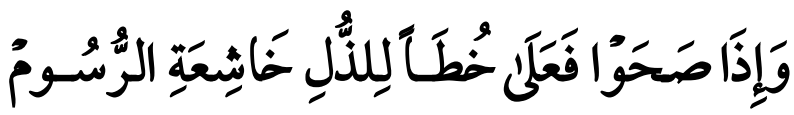

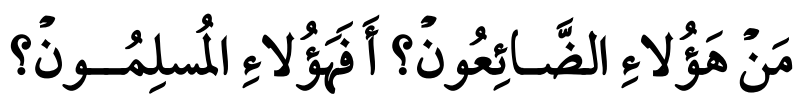

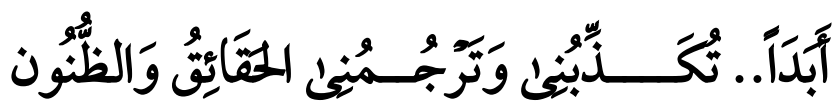

*******

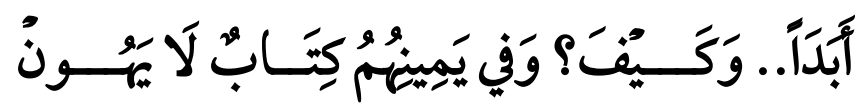

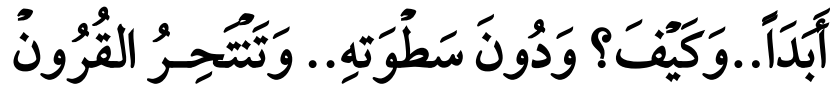

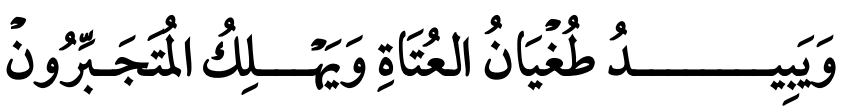

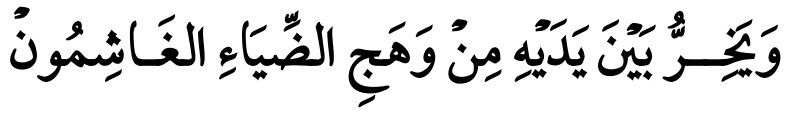




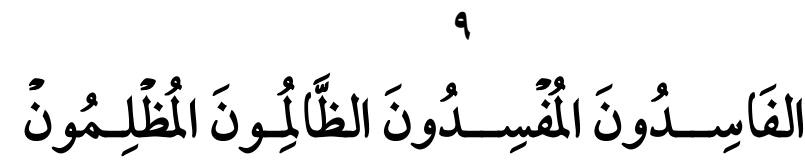

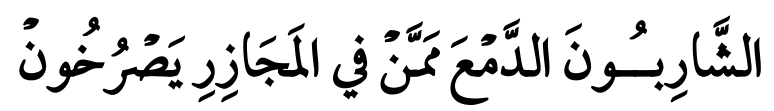

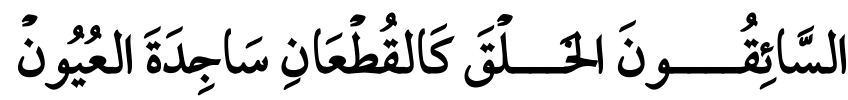

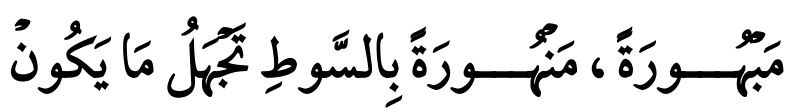

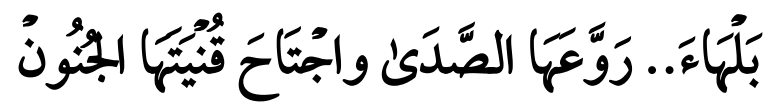

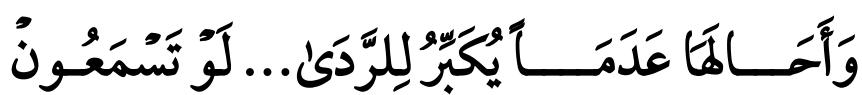

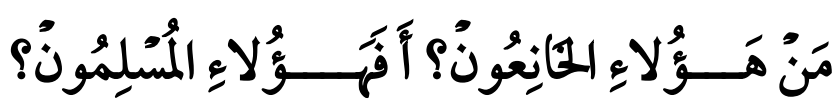

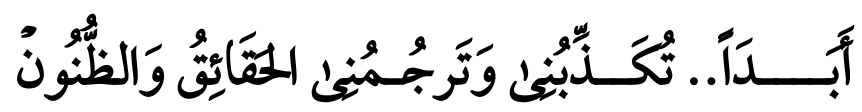

******

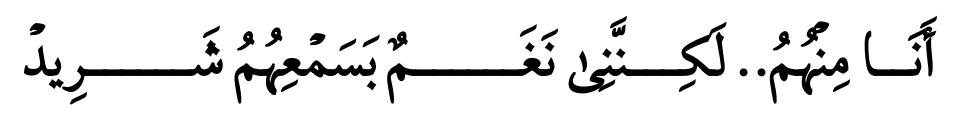

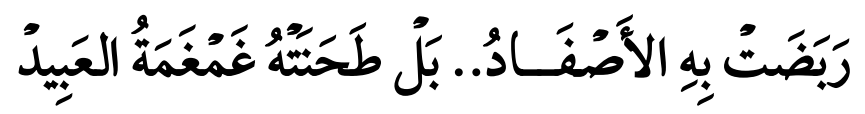

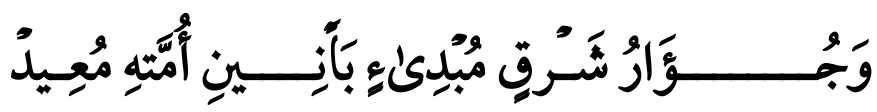

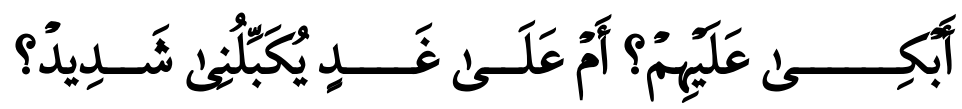

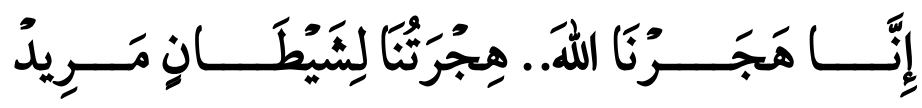

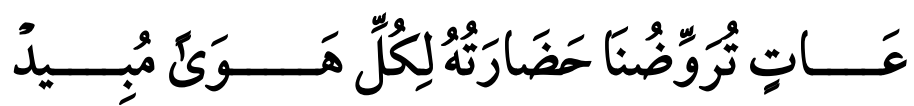

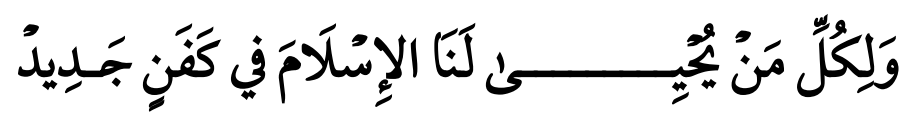

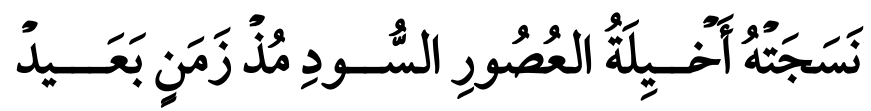




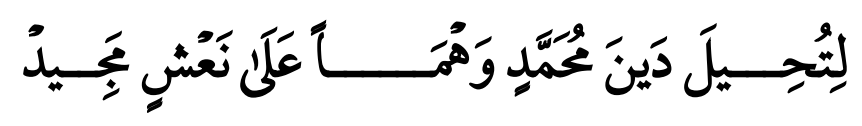

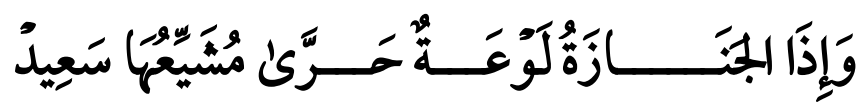

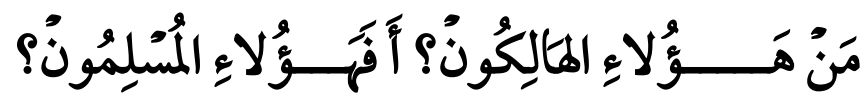

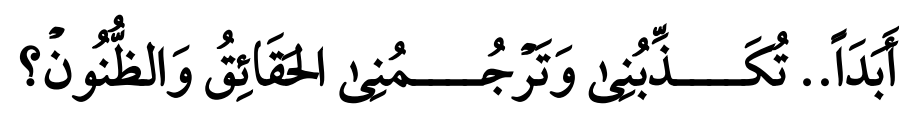

\section{********}

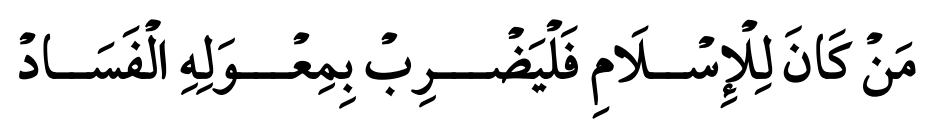

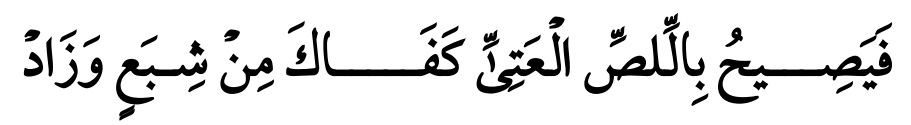

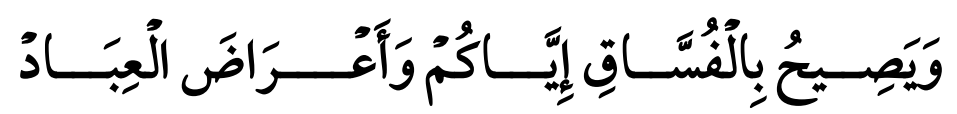

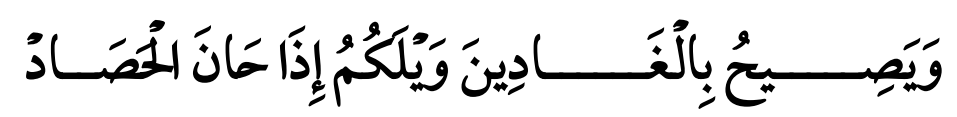

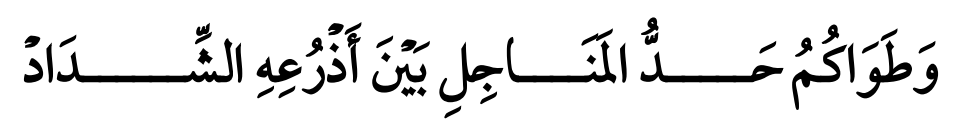

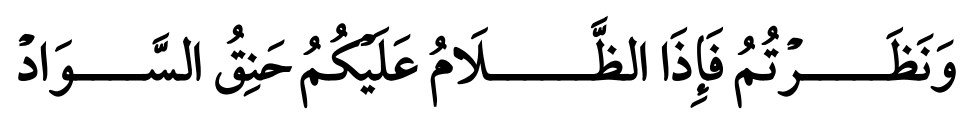

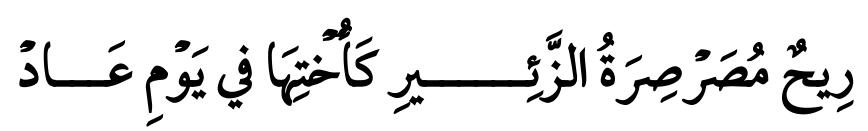

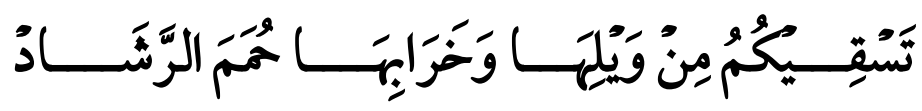

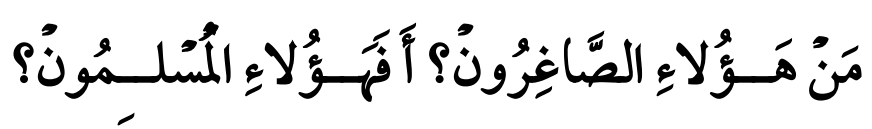

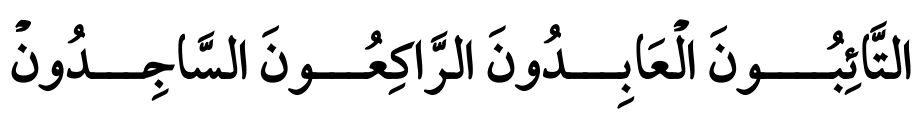


مناسبة القصيدة:

كتبت قصيدة (المسلمون) في عام ^ع 9 ام بعد نكبة فلسطين، "وتشرد أهلها، وقهر المجتمعات العربية، والإســلامية، في مصر-وغيرها على يد الاحتلال، وأعوانه، وعلئ الرغم من إســاط القصــيدة من الأعمال الكاملة للشاعر إلا أن تداولما قد كثر سنة ب . · بم في المواقع الإلكترونية، وفي بعض الدوريات، نتيجة افتقار الخاصة، والعامة إلى كلمات صادقة تعالج الشعور بالاً سئ لواقع المسلمين، والعرب، بعد سقوط العراق، وتكريس ألوان العذاب، والتدمير، والقتل لشعبى فلسطين، والعراق".(')

1 - يرابع: قراءة نقدية فن قصيدة (اللسلمون) لل شاعر محموده سن إ سماعيل - د/ عبد الرحيم عحمد المبيل - بجلة البلمعة الإسلامية للعلوم

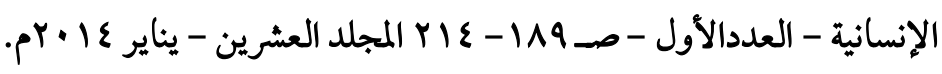




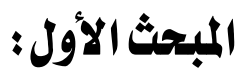

البناء الفني للقصيدة

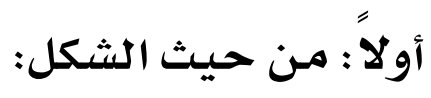

صاغ الشاعر قصيدته في أربعة مقاطع، كل مقطع كأنه بناء مستقل، لكنه يسلم إلى الآخر في تسلسل، وترابط محكم، مكررا بين كل مقطع وآخر لازمة فنية بالا ستفهام، تتم إمكام البناء التشكيلان، والتصويرئ، والمعنوئ للقصـيدة كلها، من مطلعها إلى خاتمتها، فحقق بذلك وحدة فنية، مؤداها ذلك " الرباط الذئ يضــم التجربة، والصـور، والانفعالات، والموسـيقلى، والألفاظ في وشـاح خفي، أثيرىن، وبهذه الوحدة تتكامل

القصيدة، وتدب فيها الحياة"(')

\section{التجديد مِِ شكل القصيدة}

و التجديد في شكل القصيدة ليس خاصا بشعر(محمود هسن إسماعيل) بل هو ظاهرة شاعت لدئ شعراء مدر سة (أبو لُلو) تراها عند (على محمود طه) في قصيدتيه (الجندول) و(ليالى كليوباترا) كما تراه عند

غيره)

و قد أصــل لهذه الظاهرة من التجديد بتنويع القوافي بعض الثقاد، وذكر له شــاهدا من شـعر امرئء

القيس في تأصيله لفن الموشحات الأندلسية، كلون من آلوان التجديد في شكل القصيدة العربية(")

و هذه الظاهرة عدها بعض النقاد خروجا على عمود القصـــدة العربية، يقول أحدهم بعد إثــادته

بالقصـيدة العمودية: "وإن كان شـعراؤنا المعاصرون- بتأثير الرغبة في التجديد- قد أجازوا لأنفسههم آن تشتمل القصيدة على عدة أوزان، إذا تعددت مواقفها وآفكارها... وأجازوا كذلك تعدد قوافي القصيدة الواحدة

1 - الشعر المعاصر علئ ضوء النقد المديث - مصطفى عبد اللطيف السحرتئ - صـ Y A .

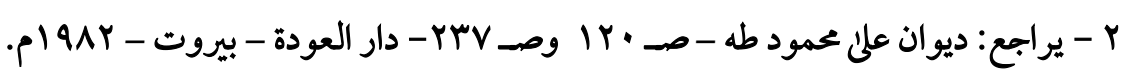

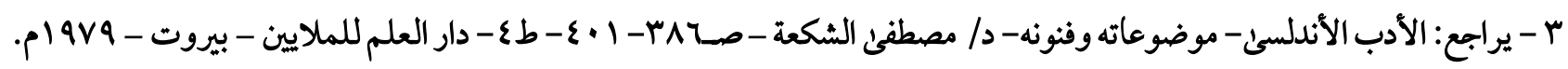


بجاراة لفن المو شحات الأندل سية، وتحررا من سلطان القافية، وجعل الكثير منهم لكل مقطع قافية، إذا كان كل مقطع يمثل تيارا فكريا متميزا :"() كما عدها البعض الآخر تجديدا يحقق الوحدة الفنية، والنفسـية في القصــيدة، ففيه تترابط المفردات، والجمل فيها بينها برباط وثيق، والصور ببعضها، في خط شعورئ، ونفسى يجمعها، حتى يكون كل جزء عنصرا فاعلا في بناء القصيدة كلها، فتغدو "عملا فنيا تاما، يكمل فيها تصوير خاطر، أو خواطر متجانسة، كما يكمل

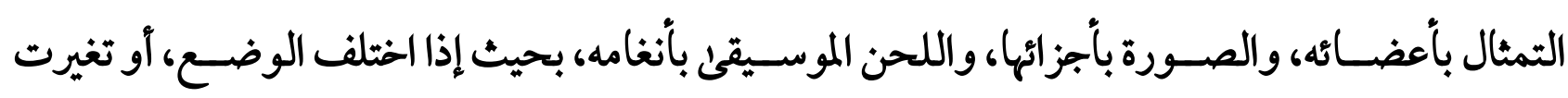
النسبة، أخل ذلك بوحدة الصنعة، وأفسدها.." (") هذا، و من يتفحص بناء القصيدة، و طرائق التعبير، والتصـوير فيها يلحظ ترابطا، وانسـجاما يحقق مقولة العلوىن: " يجب أن تكون القصـيدة كلها كالكلمة الواحدة، في اشتباه أولما بآخرها، نسجا، وحسنا، وفصاحة، وجزالة ألفاظ، ودقة معان، وصواب تأليف، وآن يكون خروج الشاعر من كل معنى يصنعه خروجا لطيفا، حتى تخرج القصيدة كأنها مفرغة إفراغا.. لا تناقض في معانيها، ولا وهُخَ في مبانيها، و لا تكلف في نسـها، تقتضى_كل كلمة ما بعدها، و يكون ما بعدها متعلقا

r) بها. مفتقرا إليها.. (r)

و قد أدى أ سلوب الا ستفهام الإنكارئ، الرافض لواقع المسلمين دورا رئيسا في بناءها من مطلعها إلى إن خاتمتها، استهلت به القصيدة، و ختمت به، و استهل به كل مقطع من مقاطعها الأربعة، وكذلك ختم به، فكان الا ستفهام مفجرا صور المعاني، واً ساليب البلاغة في القصيدة كلها، يلهب به الـشاعر نفوس المسلمين، و يسـتفزهم، بتصـوير واقعهم الذليل الخانع - ليبرز لهم في النهاية سـبيل الخلاص، راسـا لهم طريق العز الذئ هجروا آسبابه.

كا نوع الشاعر في مو سيقى القافية في كل مقطع، فجاءحرف الروى في المقطع الأول (ميا) (التخوم) ملائح) ما يريد الثـاعر خلعه عليهم من تضـام، وتجمع ظاهرئ، لكنه يممل بين مطاويه التيه، والتخبط، ولو أتى بمرادفه (الحدود) ما أفاد ذلك، لأن "الميم تعبر عن تضام، أو استواء ظاهرئ لشىءء أو على شئء، وذلك

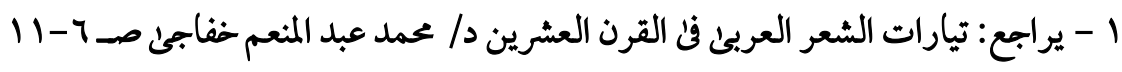

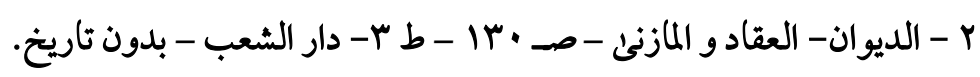

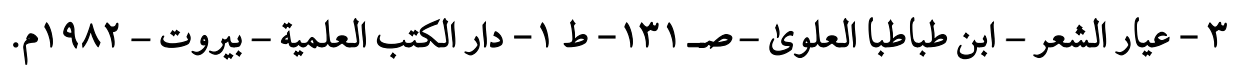


المعنى اللغوئ لما يلتقى مع الشعور بتكونها بالتقاء الشفتين في نقطة أقرب إلى ظاهر هما، مع خروج زمير المجر

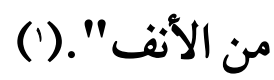

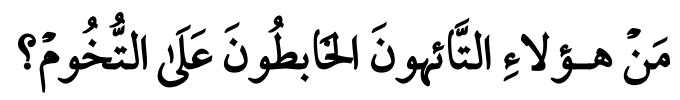

وفي المقطع الثاني، وفي أسلوب الاستفهام الذئ كان لازمة بين المقاطع، آتئ الروئ(نونا) تالية حرف

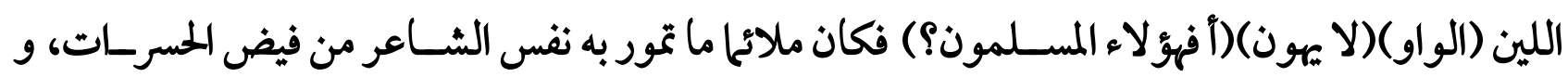

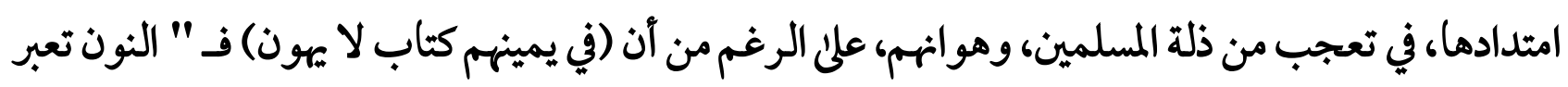

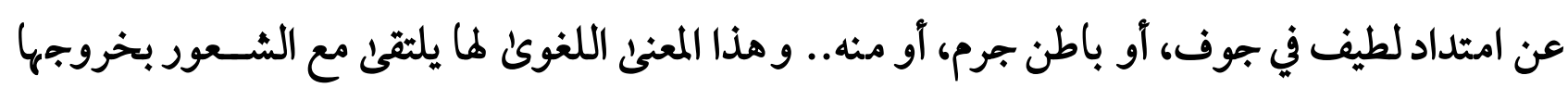

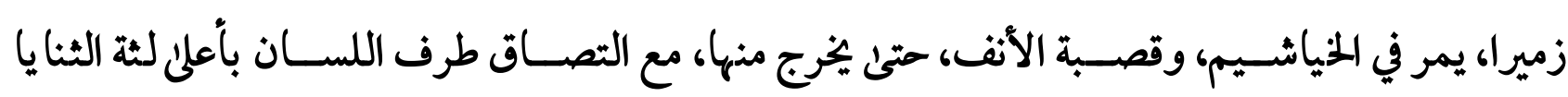

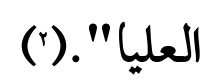

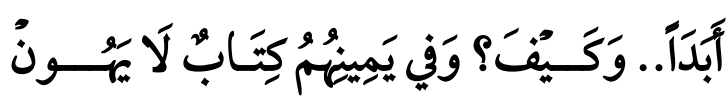

أما في المقطعين الثالث، والرابع، جاءحرف الروي (دالا) تالية حرف اللين (الياء) في الثالث (شريد)

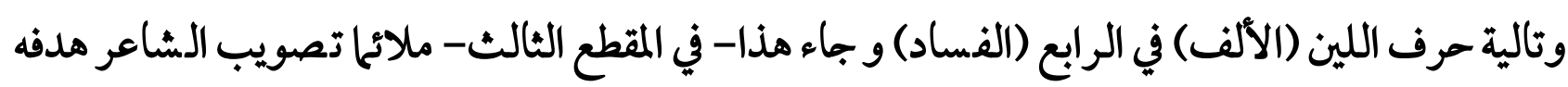

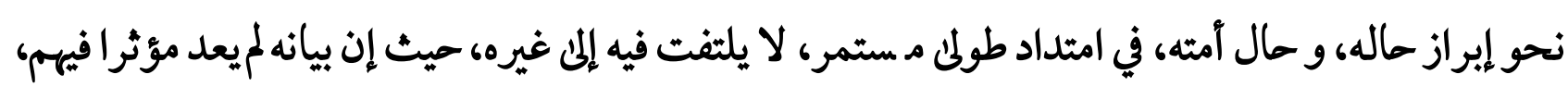
فهو (منهم لكنه نغم بسمعهم شريد..إلخ)

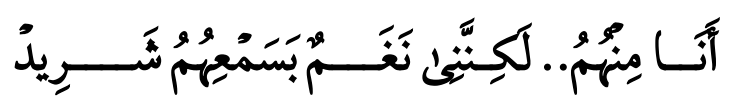

كما جاء - في المقطع الرابع - ملائم) تصـويب هدفه نحو إبراز سـبيلن العلاج من خلال الأمر بمحارية

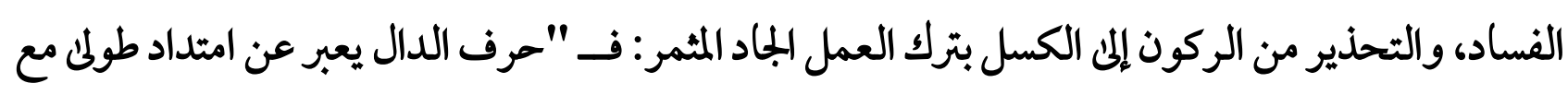


انحصـار، ألى: احتباس عن العِرَض، و ذلك أخذا من (الدَّد: اللهو واللعب) الذئ يغرئ بالاسـتمرار، مع

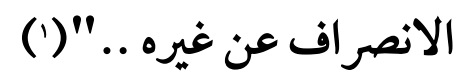

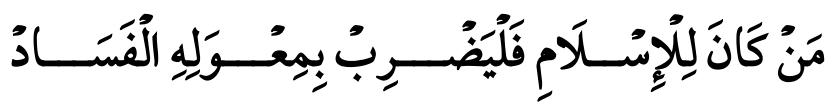

هذا وقد جاء حرف الروئ- في قافية مطلع القصـيدة، والمقطع الأول (ميا) وفي اللازمة بين المقاطع،

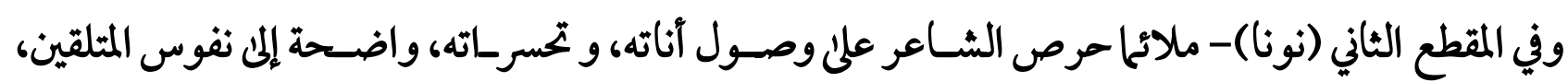

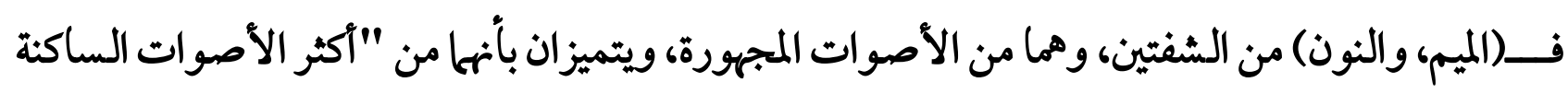

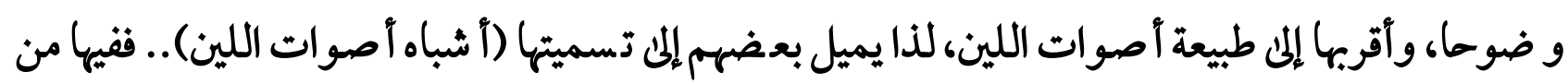
صفات الأصوات الساكنة أن بجرئ النفس فيها تعترضه بعض الحوائل، وفيها أيضا من صفات أصوات الميات اللين

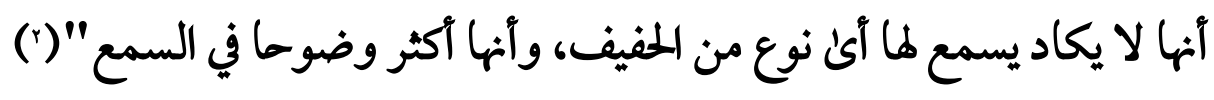

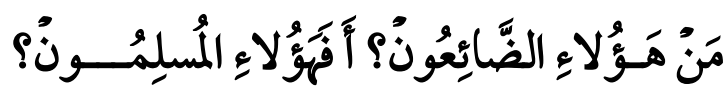

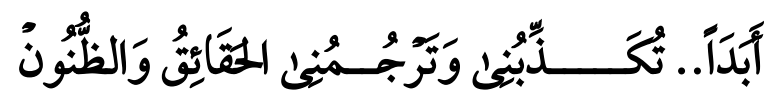

كما أن تكرار حرف النون يتسـق ومواقف الحزن المكتوم، والنفس المفعمة بالأسـئ، والشــن "فإن لبعض الأصوات قدرة علن التكيف، والتوافق مع ظلال المثاعر في أدق هالاتها" (ت). وفي هذا ما يشير إلمى ارتباط إيقاع حرف الروئ، و تكراره، بمضمون القصيدة، و أثره النفسلى، حيث " يتيح لمتلقى الشعر فسحة من الصمت، تجعل إيقاع الروئ أعلق بذهنه من غيره، فإن دلت -القصيدة- علئ

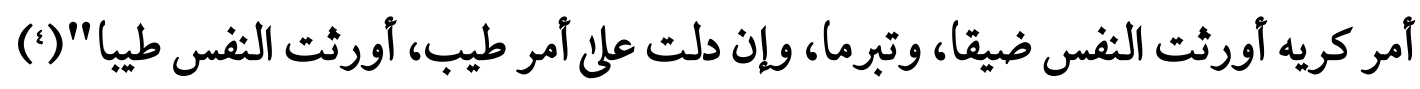
وإذا كان الشاعر قد نوع في القافية با يلاتم مضمون كل مقطع، فقد نوع في المستفهم عنه (المسلمون)

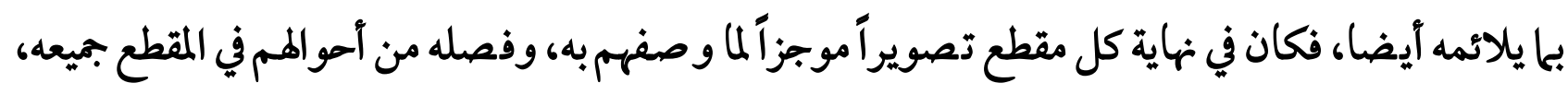

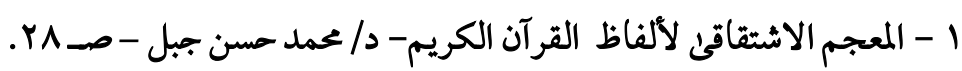

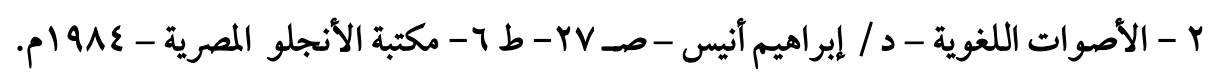

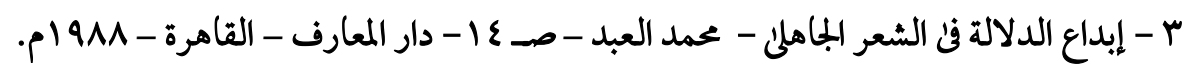

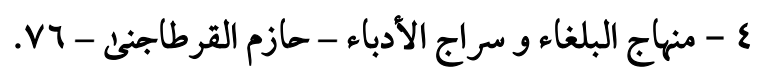


يسـلم إلى ما بعده- وسـأرجخاء الحديث عن ذلك إلى موضــعه من التحليل في نهاية كل مقطع - فقي مطلع القصيدة كان المستفهم عنه (التائهون الخابطون..):

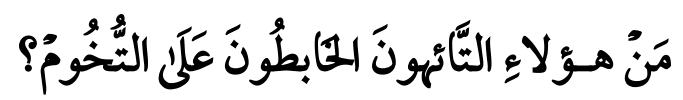

وفي خاتمة المقطع الأول كان المستفهم عنه (الضائعون):

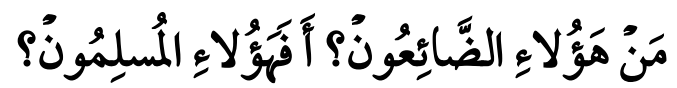

وفي خاتمة المقطع الثانى كان المستفهم عنه (الخانعون):

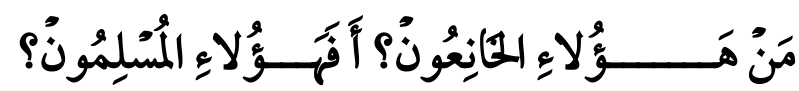

وفي خاتمة المقطع الثالث جاء المستفهم عنه(المالكون):

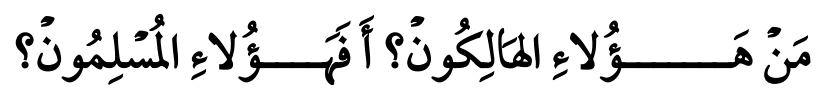
وفي خاتمة المقطع الرابع والقصيدة جاء المستفهم عنه(الصاغرون):

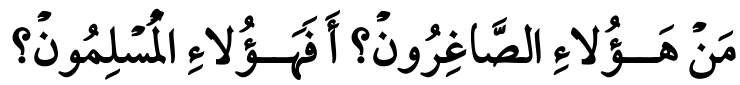

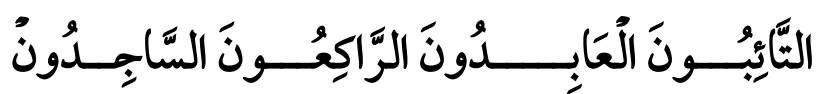

\section{******}

ثانياً: مـن حيث المضمون:

تجربة الشاعر في هذه القصيدة يمكن عدها من الأدب الإ سلامي، و يمكن سلكها في شعر الحما سة، فمضمونها التحسر علئ ما وصل إليه حال المسلمين، والعرب من تخبط، وضياع، وملاك، وخنوع، وصغار، بعد نكبة ســنة 9 ام التي تحقق لإسرائيل فيها حلم الوطن، بعد أن كان شـعبها آشـتاتا متفرقة، هذا الحلم الذئ لميكن ليتحقق لولا تمحور كل دولة إسلامية على شأنها الداخلي، و تفرق كلمتهم بعد هذه الحرب. (') من ثم كانت هذه القصيدة نفثة مصدور، عبر فيها الشاعر عال يجول في نفسه تجاه قضية أمته، بألفاظ، و

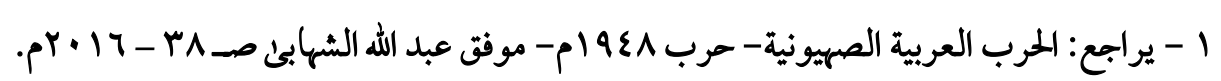


أساليب موحية، والإيحاء في الشعر من عناصر حيويته، وجماله، "ولو خلا الشعر من الإيحاء لبطلت قداسته، وتهدم هيكله، وهزلت قرابينه، وأصبح صناعة من صناعات السوق، أرخص من سائر الصناعات ثمنا،

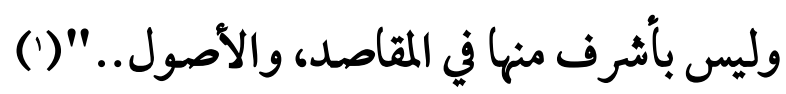

وقد وظف شاعرنا أ ساليب البالاغة، وصور البيان، توظيفا بارعا يوحمى بأنه قد عاث في قلب أمته، و في شـعاب نفوس أهلها، يئن لأنينهم، ويأسسى لنكبتهم، فجاء تعبيره عن ذلك في تصـوير حلى، يفيض إيهاء" تتحرك به عواطف المتلقى، ويهتز له و جدانه، لما فيه من عمق النظر، ووفرة الخيال، و هذا لا يكون إلا لمن يتحسس قضايا الحياة، ويفكر فيها، ويتخللها بوعيه، ويبث فيها من هواجسه، وأحلامه، ومخاوفه.."(") ولا يغيب عن خاطره- وهو يصور واقع أمته- آن الداء العضال الذئ ظل ينخر في عظام شعوبها، هو هجرتهم تعاليم إسلامهم السمح، إلى حضارة غربية زائفة، تصور لهم دين محمد- صلن الله عليه وسلم- وهما

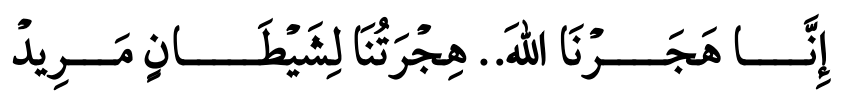

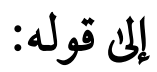

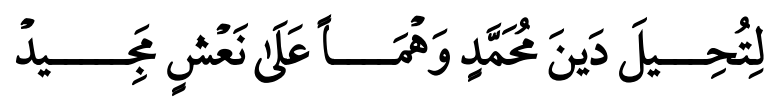

米楼楼米

1 - مراجعات فن الآداب والفنون - عباس محمود العقادصـ9

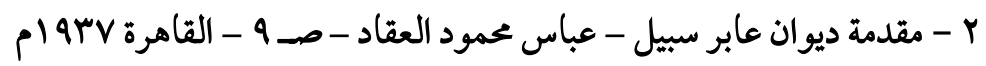




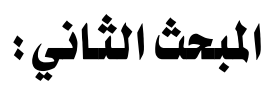

وصف حال المسلمـين بين التخبط و الضياع

و المبحث يتناول وجوه بلاغة المقطع الأول، الذئ يعتمد الاسـتفهام الإنكاري، في مطلعه، وخاتمته، و قد وظفه الشاعر توظيفا جيدا، فكان أداته البلاغية التي يستفز بها نفوس المسلمين للنهوض من كبوتهم، كما كان مرتكز البلاغة في الق صيدة، وكأن عناصر التصوير، و آ ساليب البلاغة، قد تولدت منه لت سهم معه في تشكيل لوحة كلية، استهلت بتصوير تيه المسلمين، وتخبطهم، إجمالا، في الاستفهام الرافض لو اقعهم في قوله:

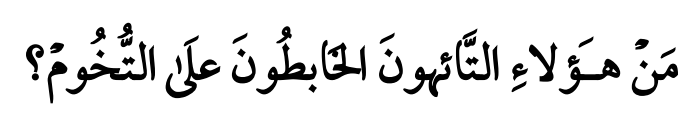

ويتخلص الشاعر من الإجمال إلى تفصيل حالفم مع الطغيان، أو المستعمر - ببراعة فنية، لا يكاديشعر معها المثلقى بفجوة في الصياغة، لمشدة سبك الكلام، وإحكام ذسجه - بأن جعل لأبصارهم خُطاً، هذه الخطاً قد أصـا بها رهج الزوابع، والغيوم بمرض العشـئ، الذئ جعلهم تأهون، خابطون ، لا يدرون ولو إثــارة تهديهم إلى طريق الخروج من كبوتهم، فيقول:

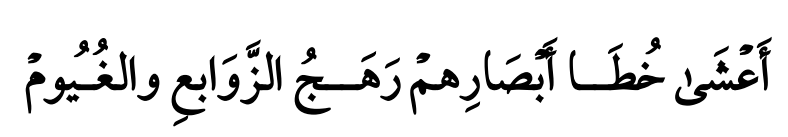

هذا التفصسيل الذئ ختم بهروب النوم من أجفانهم لتكون غفوتهم- إذا غفوا- على مواطلى كل جلاد

غشوم:

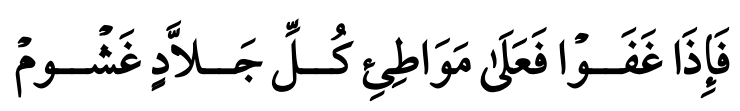

و ليكون صحوهم- إذاصحوا- على خطاً للذل خاشعة الرسوم:

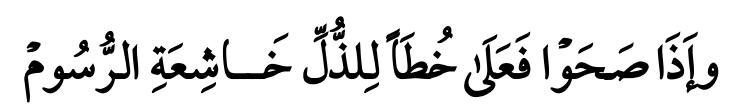

و بين خطا أب صارهم المصابة بمرض العشىلى، و صحوهم على خطاً للذل خا شعة الر سوم، وظفت الاستعارات - تصريية و مكنية، و تبعية- وغيرها، توظيفا بارعا لتسهم مع الاستفهام الإنكارى في تصوير مظاهر هذا التيه، وذاك التخبط في واقع المسلمين، فمعنى الاستفهام يسرئ في المقطع، من مفتتحه إلى خاتمته مفردات و تراكيب و صور - بل يجيطه من بين يديه، ومن خلفه. 
تراه في اسـتفهامه عنهم بــــ(مَنْ) وهو يعرفهم جيدا، ويعرف عزهم، و من يعرفهم، ويدرك قيمتهم لا

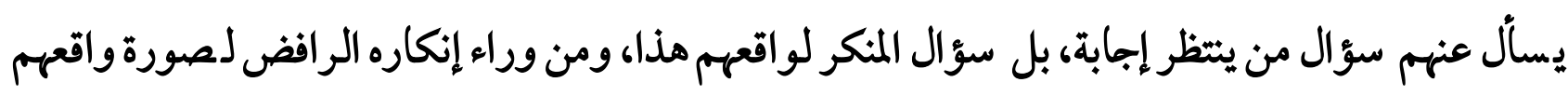
التائه، المتخبط، تبرز صورة عزهم، ومجدهم الغابر، ومن خلال المفارقة بين الصورتين يستشف تحسر الثاعر عليهم، و على تخبطهم في ظلام واقعهم المرير.

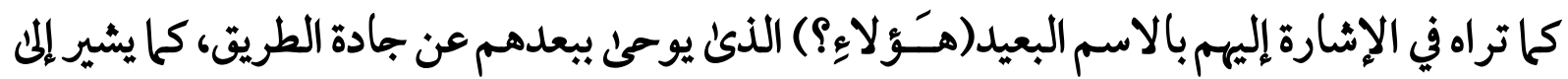
أن الشاعر لا يعرف من المسلمين تلك الصورة المتخبطة، التائهة، إنما يعرف منهم صورتهم الماجدة، الرشيدة،

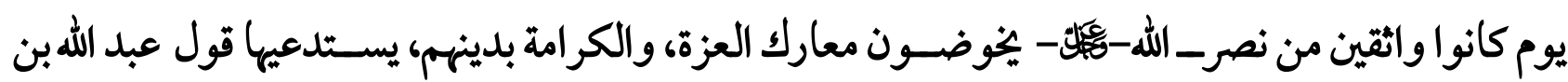

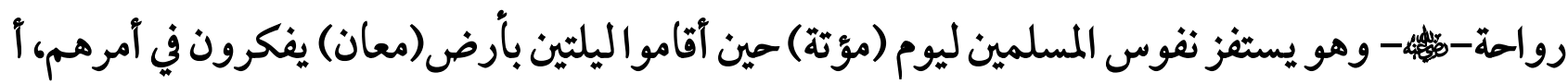

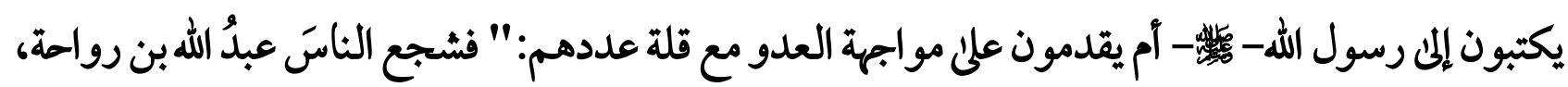

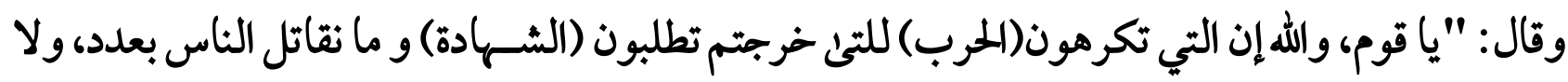

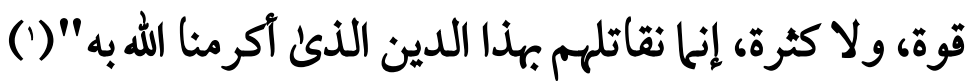

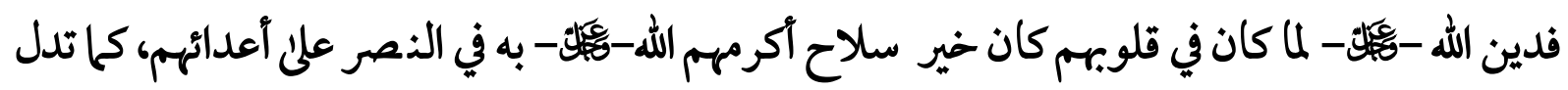

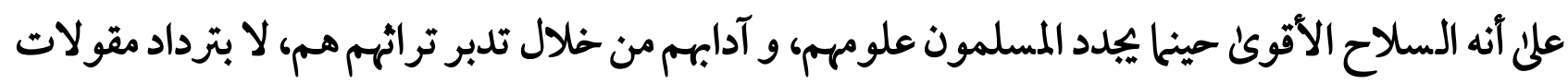
مقتطعة من تراث غيرهم، و ليسـت هذه دعوة للانغلاق، بل هيل دعوة إلى قراءة علوم الأمم كلها، قراءة

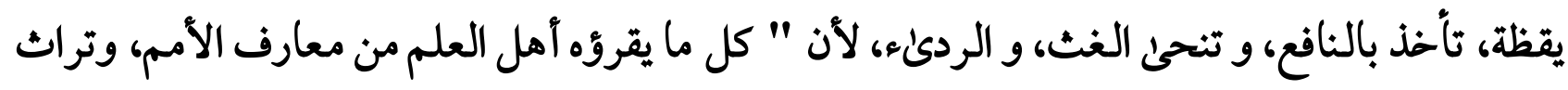
الإنسـان إنما هو غذاء، و شــذ، و إيقاظ، وتنبه، و كل هذا من أدوات النظر، والثدبر... وفي كلام علمايثنا،

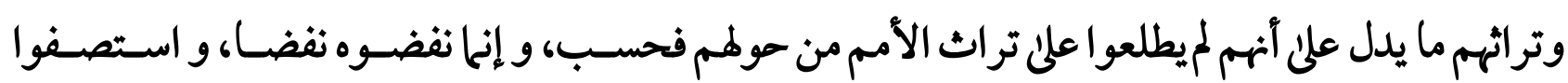
صفوه، ولميدخلوا شيئا من ذلك في علوم العربية، والإسلام"(') ويجا أن واقع المسلمين في فترة ما بعد حرب 1 9 أم يؤيد حيادهم عن هذه الصورة، من ثم برزتحسر

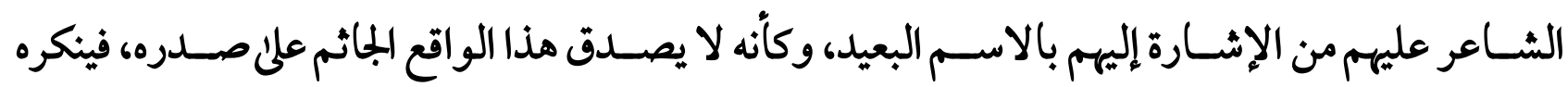
متحسرا، ليكون الإنكار، وما تولد عنه من تحسر مستفزا نفو سهم لتغيير هذا الواقع البغيض، في كل بجالات التهات

1 - سيرة ابن مشام - جـ ع- صـ IV - سلسلة الذخائر rاץ - الميئة العامة لقصور الثقافة.

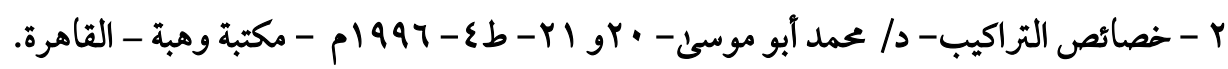


حياتهم المادية، و العقلية، والفكرية، والأدبية.

من ثم يعلى الشاعر من نبرة التحسر عليهم، مبرزا أسى نفسه لما يراه من صورتهم، فيصوغ المستفهم عنه

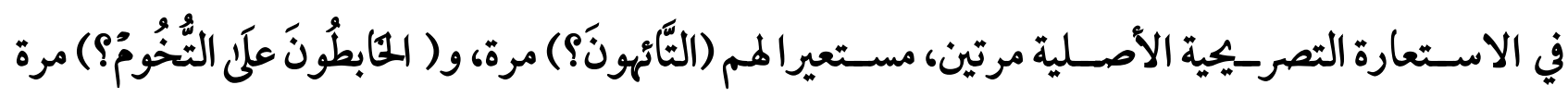

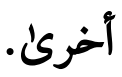

و الاستعارة قد أزاحت صـورة المسـلمين الماجدة، التي وعتها ذاكرة الثـاعر، ليحل محلهاصـورتين:

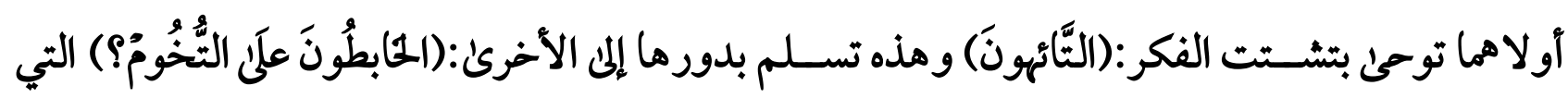
توحلى بعدم اهتدائهم إلمى بداية طريق للخلاص، فخطاهم تخبط خبط عشواء، و "مادة (خبط) تتمحور حول:

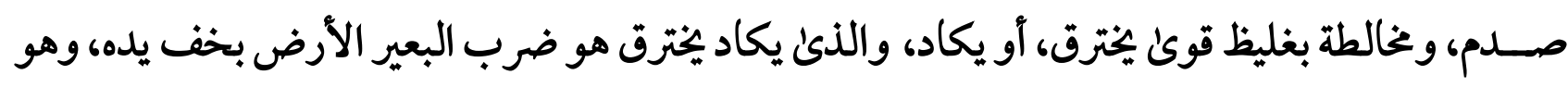
ضرب غليظ قوئ، ولغلظه قيل: يخبط خبط عشواء الليل، وهئ الناقة التي في بصرها ضعف، تخبط لا تتوقى

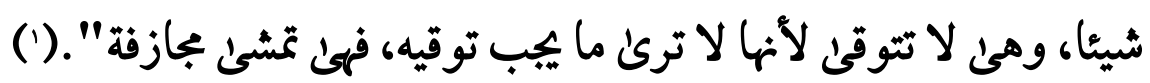
وقد صيغت الاستعارتان في صورة اسم الفاعل (التأهون- الخابطون) فأفادت ثباتهم على الوصفين، فهم مشتوا الفكر، موزعة نفوسهم بددا، محجوب علن فكرهم فلا يعملونه في واقعهم، كما أشار تعريف المسند

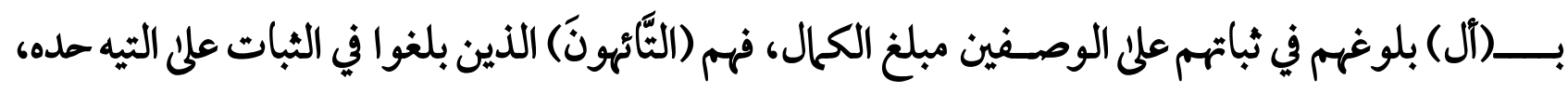

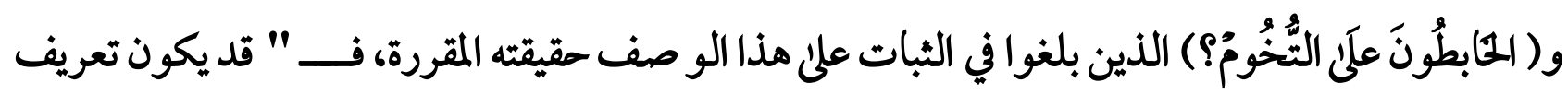

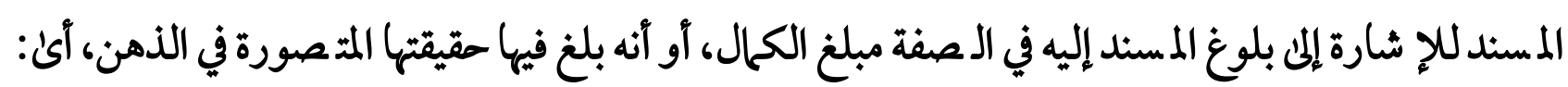

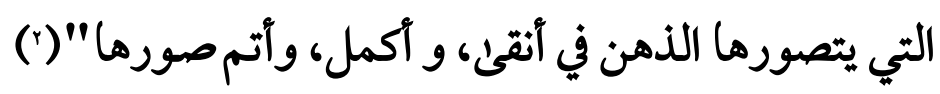
من ثم كانت هالفم أدعى إلى إنكار الشاعر صورتهم، فانفطر قلبه ه سرات عليهم، وعلنواقعهم، كما

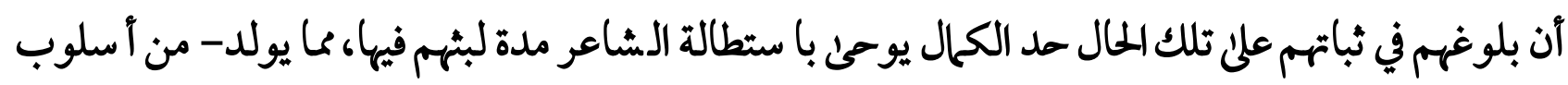

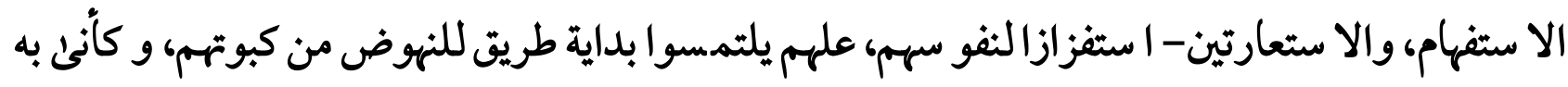
يصرخ فيهم: كفاكم ثباتا علن هذا، قفوا في وجه الاحتلال، والطغيان، والفساد أيا كان لونه، وجنسه، ونئه ويؤيد

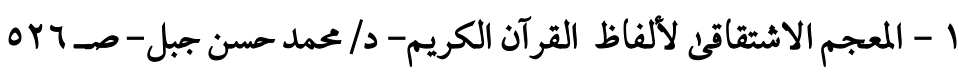

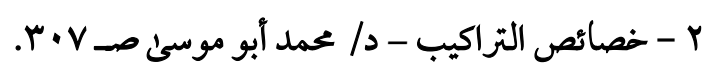


هذا تصر-يكه بهذا في المقطع الأخير، في صرخات متتالية، يوقفهم فيها على علاج الأدواء التي انتهت بهم إلى

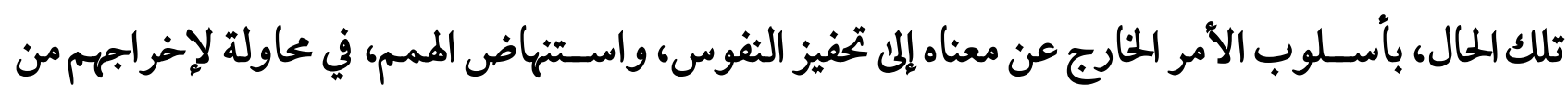

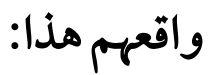
من كان للإسلام فليضرب بمعوله الفساد ..إلخ

وإذا كان الشاعر قد صور واقعهم بطريق الإجمال في البيت السابق، فقد فصل هنا مظاهر جثوم هذا الواقع المرير علإصــدورهم، ليسـتمر بذلك دور أسـلوب الاسـتفهام في التحسر -على واقعهم من جانب،

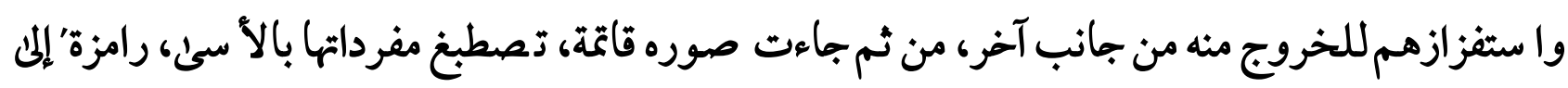

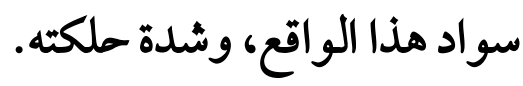

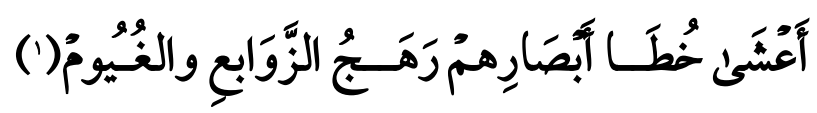

وصياغة المقطع في صورة التفصيل بعد الإجمال لها ميزة بارعة في تسلسل المعاني، وربط المتلقى بالمبدع،

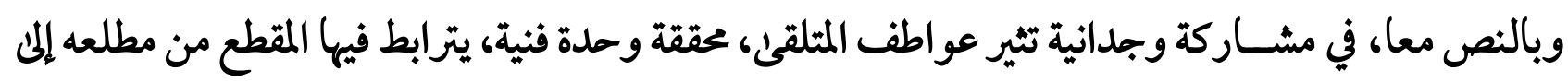
خاتمته، مقررة أثر هذا الأسلوب، الذنى يشفي غلة النفس إلى وضوح المعلوم بعد خفاء المجهول "واعلم أنك

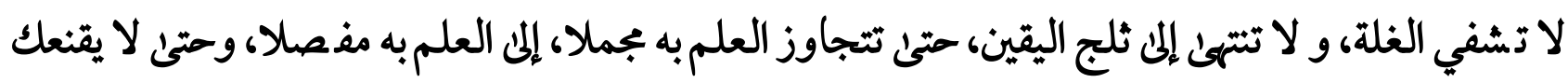

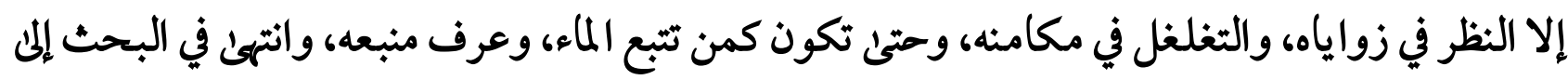
عروق الشجر الذئ هو منه.." (") (ل) وفي قوله: (أعشى خطا أب صارهم) صورة مبتكرة، وطريفة، وغريبة، حيث جعل لأب صارهم (خطا)

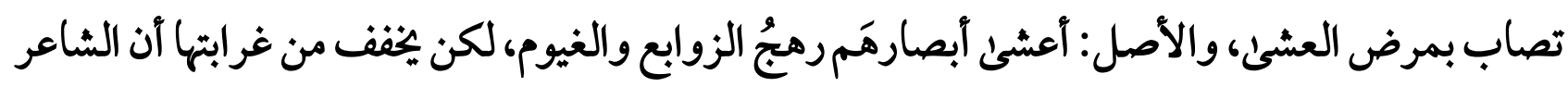

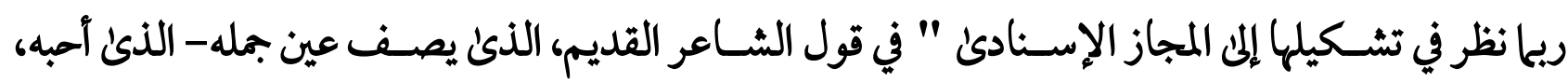
فتناسئ به طلاب العامرية- بأنها تجوب له الظلماء:

1 - أعشى: من العشا كالفتن، وهو: سوء البحر بالليل، والنهار، يكون فن الناس، و الدواب، و الإبل، و الطير- المعجم الا شتقاقى لألفاظ

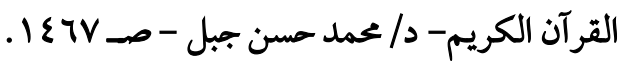

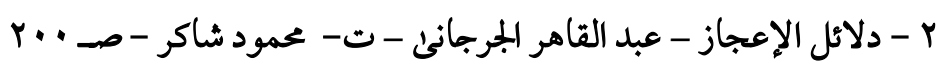


تجوب له الظلمةَعينٌ كأنها * زجاجة شرب غير ملألخ ولاصفر

فقدأ سند الجوب الذئ هو قطع الظلماء إلى العين، والأ صل: يجوب الجمل الظلماء بعينه، لكنه عدل إلى

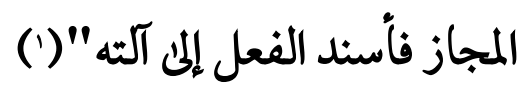

وكأن إسناد الجوب للعين - وهو للجمل، وهئ آلثه- خيل لشاعرنا آن للعين أرجلا تقطع بها الظلماء،

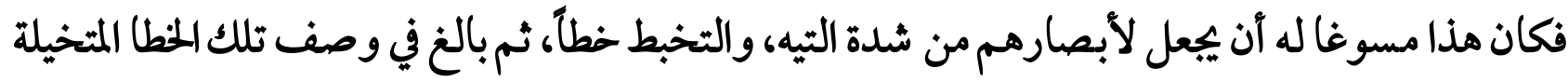
لأبصـارهم فجعلها قد أصـيبت بمرض العشـا-عن طريق تراسـل المواس، الذئ أعطى للأرجل صـفة فئة

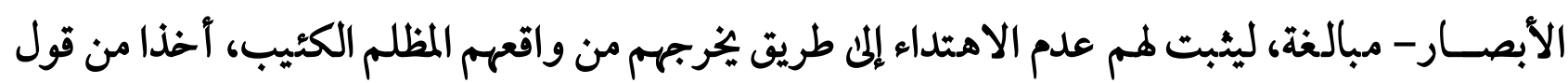
العرب للاضال والمتخبط في رأيه وفعله: (يخبط خبط عشواء الليل) و قد تكون ال صورة كلها كناية عن عدم اهتدائهم، فنكون كناية مصورة مبنية علن المجاز.

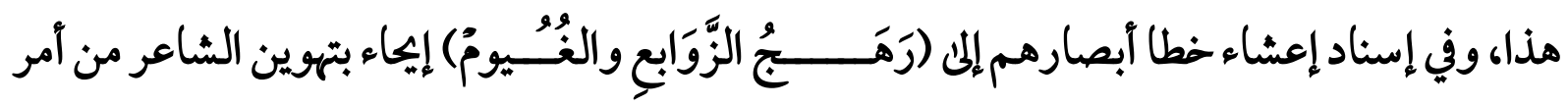
عدوهم، و التقليل من خطر طغيانه، وشره، لو التمسـوا طريقا للتوحد في مواجهته، وهو لون من اسـتفزاز

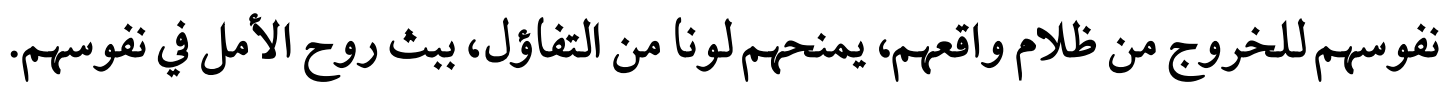
فالذئ أوصلهم إلى تلك الحال ما هو إلا شيخء هيّّن، لو تفحصوه جيدا لوجدوه رهجا للزوابع، والغيوم

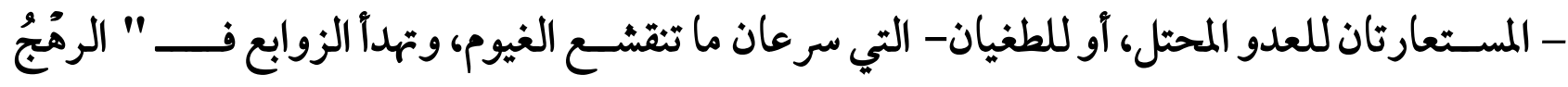

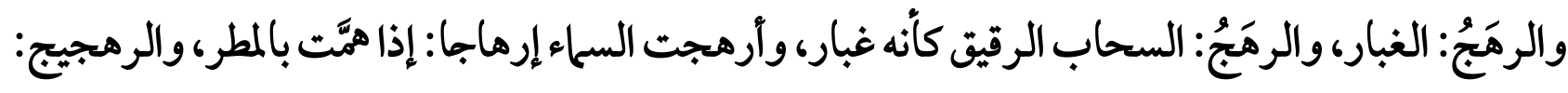

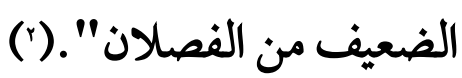

وكان للجمع بين المتباعدين - بصـياغة الاسـتعارتين متقابلتين، إحداهماصـفة لفعل الريح في وجه الأرض (الزوابع) وهلى صورة أرضية، تقابلها الأخرىن، وهلى صفة لفعل الريح في السحاب(والغيوم)، وهلى

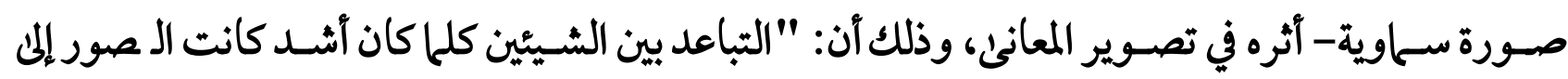

1 - خصائص التراكيب - د/ عممد أبو موسئ -صـ

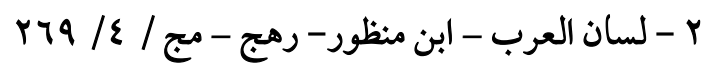


النفوس أعجب، و كانت النفوس لما أطرب، و كان مكانها إلى أن تحدث الأريحية أقرب" (') فالشاعر يستفز نفو سهم من خلال الصورتين كأنه يقول لهم : إن ما تصورتموه من قوة عدوكم وهم صنعتموه بتفرقكم، و لو اتحدتم في مواجهته، فسترونه زوابع سرعان ما تهدأ، و غيوما سرعان ما تنقشع، وفي هذا ما يلائم استفزاز مشاعرهم بالتهوين من أمر عدوهم "وهذا من جماليات الصياغة التي تعكس جماليات المعانئ المخبوءة بين طيات الصورة.."(?)

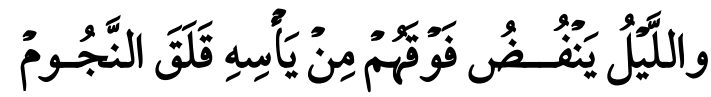

والبيت معطوف علنى ما قبله، وفيه توظيف الاسـتعارة المكنية في قوله: (والليل ينفض فوقهم ) التي شخصت الليل، ومنحته صفات الأناسى، وبثت فيه الحياة، وأرتنا- كما عبر الإمام عبد القاهر - "الجماد حيّّا ناطقا، و الأعجم فصيحا، و الأجسام الخرس مبينة، و المعاني الحفية بادية جلية."(") و شاعرنا إذ يستعير الليل لـ_(الاستعحار أو والطغيان) هنا مسقطا هموم نفسه، و واقع أمته عليه كعنصر من عناصر الطبيعة ليس بدعا، "فالشـاعر - منذ الجاملية- جعل الليل وعاء يفرغ فيه ما به من شـوق، وهمّّ، وبذلك ارتبط الليل بحاله النفسـية، وعبر عن ثقل المموم، و الأحزان التي عاناها، فبدا ليله كثيف الظلمة

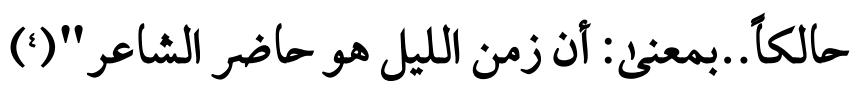
إذا فنحن أمام صورتين صورة الليل - المستعار للمحتل أو الطغيان- قد يأس من خروج المسلمين من واقعهم هذا، فهو ينفض فوقهم من يأسـه قلق النجوم، و صـورة ثبات المســلمين أمام بطشـهـهـه، ومن ثنايا تفاصيل الصورتين تظهر أوجاع الشاعر، و آلامه، و إنكاره هذا الواقع، ومن ثم التحسر عليهم، كما استشف من سياق الاستفهام الإنكارى' في مفتتح المقطع، و الذئ سرت أنفاسه في طيات الصور الجزئية في المقطع كله، بمعنى: من هؤ لاء التأهون؟ الخابطون...؟ من هؤلاء الذين أعشى خطا أبصارهم....؟ من هؤلاء الذين ينفض

$$
\begin{aligned}
& 1 \text { - أسرار البلاغة-عبد القاهر الجرجانئ - ت - محمود شاكر - صـ • } 17 \text { - بتصرف يسير. } \\
& \text { r - يراجع: نظر العقاد فخ طبيعة الشعر الحديث - صـ } 10
\end{aligned}
$$

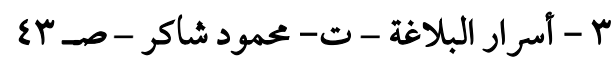

$$
\begin{aligned}
& \text { ع - أنسنة الليل فن شعر ذئ الرّمة - صـ ه - بتصرف يسير }
\end{aligned}
$$


الليل فوقهم من يأسه...؟ إلخ.

و يلاحظ أن الاستعارة المكنية قد بنيت على تشبيه مقلوب، لأثه شبه الليل بالمستعمر، أو الطغيان، على

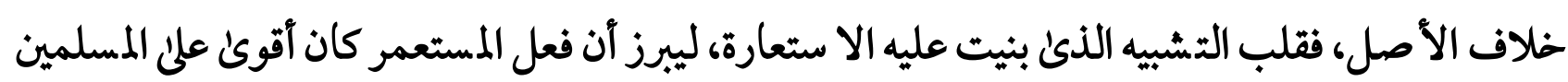

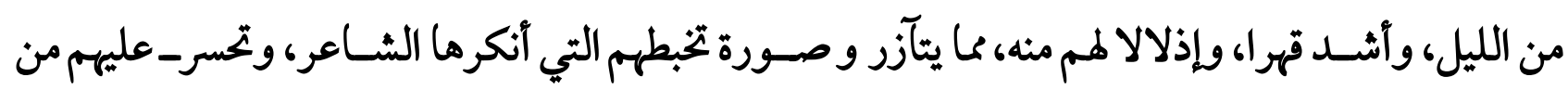
خلالما في صياغة الاستفهام في مطلع هذا المقطع.

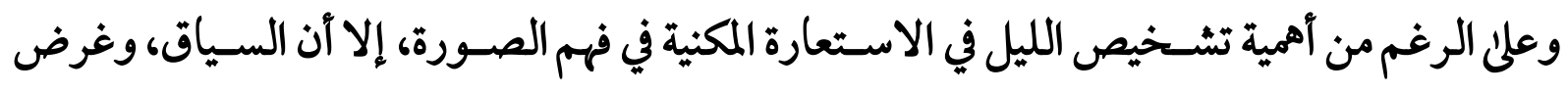
الكلام يسـتدعيان إبراز فعل الليل في تعذيب المســلمين، وهذا ماصــورته الاسـتعارات التبعية في الأفعال المسندة إلى (الليل) في قوله: (ينفض فوقهم) أو إلمى ضميره (من يأ سه- وي سوقهم زمراً) أو إلما غيره كقوله:

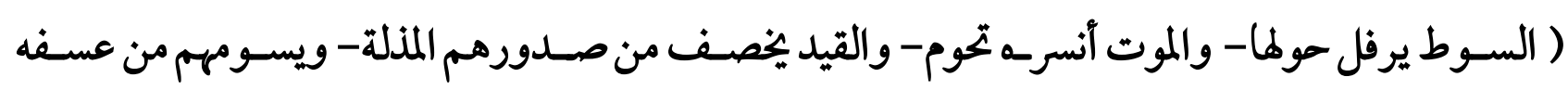

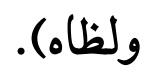

هذا وقدصيغت الاستعارة التبعية الأولى في قوله:(الليل ينفض فوقهم من يأسه قلق النجوم) من خلال

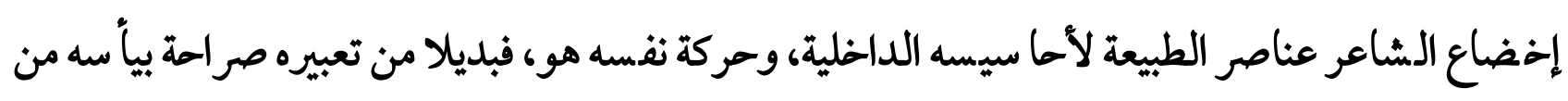
خروجهم من واقعهم الكثيب، تراه أسند الأفعال إلى الليل (ينفض فو ههم) أو إلى ضميره (من يأسه - ويسوقهم زمراً) ليعكس يأسه هو من مكوثهم على العيش في هذا الواقع، ومن ثم إنكاره لحلالمم تلك، وتحسره عليهم.

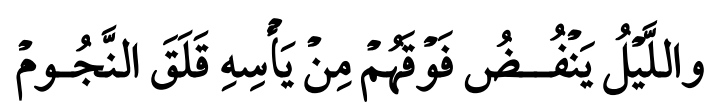

وقدا ستعار النفض للحركة القوية الـصادرة من إ شعاعات النجوم، وجعلها قلقا منها على المسلمين، وتحسر اعلى ثباتهم على هذا الواقع الميتن، ثم اشتق من المصدر الفعل المضارع (ينفض) لتتحرك بقوة، ثم جعل

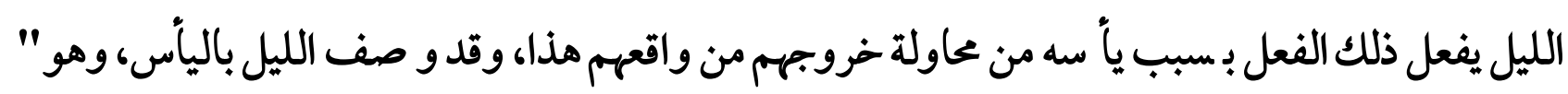

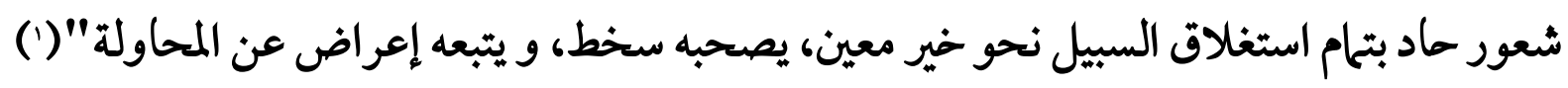
من ثم كانت الحركة في الاستعارة التبعية في الفعل (ينفض) مصورة فعل المستعمر - المستعار له الليل-

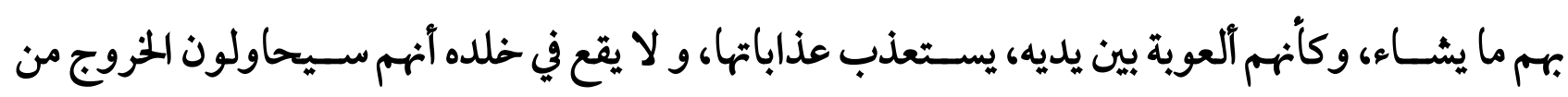
I - المعجم الاشتقاقي لالفاظ القرآن الكريم- د/ عمد حسن جبل - يأس- TTV 


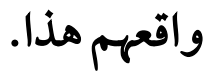

كحا أن تصويره التموج، و الاضطراب في الأشعة الطبيعية للنجوم بالقلق لواقع المسلمين يبرز إشفاق النجوم عليهم، فالقلق: "الانزعاج، والاضـطراب، والحركة، وهو: أن لا يسـتقر الشــــ في مكانه، ومنه

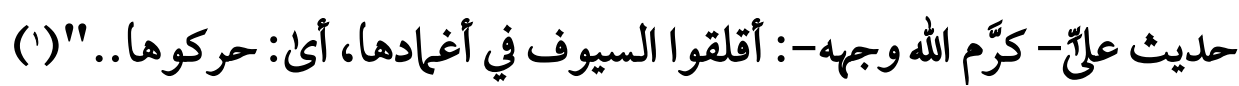
فإذا كان الليل المسـتعار للمسـتعمر قد يئس من اسـتفاقتهم من تخبطهم، وتيههم، فأثار إثــفاق النجوم عليهم، دلالة علني أنه قد أمن جانبهم، فلم يعد هناك تخوف من محاولة وقوفهم في وجهه- فإن هذه الحال تعد قمة المأساة، مما يجلان تحسر الشاعر عليهم، حيث خلع هموم نفسه، وتحسره على عناصر الطبيعة، ليصور آن يأسه من ذلك قد تعدى الأحياء إلى الجمادات، موظفا الليل توظيفا بارعا، ملائم) مقصود كلامه، فمنحناصورة لليلٍ طاغية، معتدِ على المسلمين، يستعذب عذاباتهم، ويسوقهم زمرا إلى موت محقق، وهم ثابتون، لا يحاولون بجرد

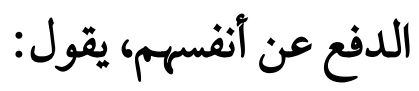

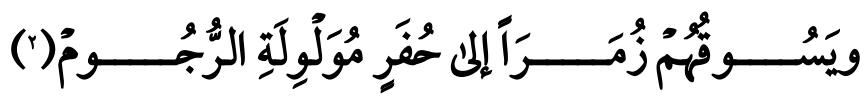

هذا، و قد جاء عطف البيت على ما قبله بجلّيّا ارتباط الاسـتعارة في:(ويسـوقهم زمرا) بجا قبلها، فلما أفادت الاستعارة الأولم(ينفض فوقهم) أمن المستعمر جانبهم، جاءت الثانية هنا معطوفة عليها لتفصل ألوان عذاباته لهم، في قسـوة لا تعرف رحمة، يفعل ذلك باطمئنان تام أنهم لن يتحرك منهم سـاكن، وكأنه لما آمن جانهم في الأولى، ساقهم زمرا وبكل قسوة في الثانية. فقي قوله (ويســوقهم زمرا)اسـتعارة تبعية، بناء علان أن فعل السـوق مسـتعار لتحام تمكن الليل منهه، ويؤيده أن فعل السوق قد أ سند إلى الليل، و هو لا يسوق حقيقة، و الا ستعارة تصور قسوة الليل الطاغية

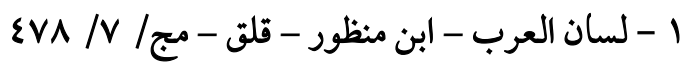

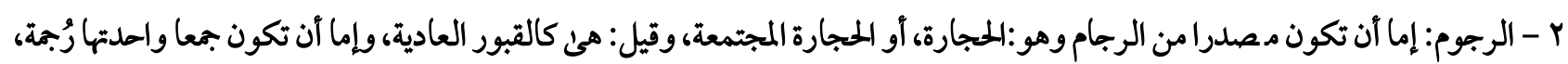

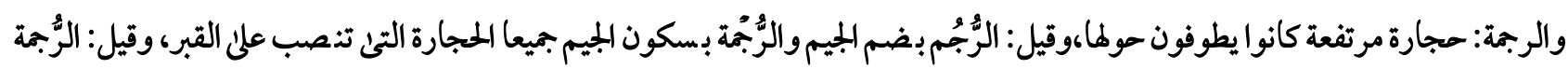

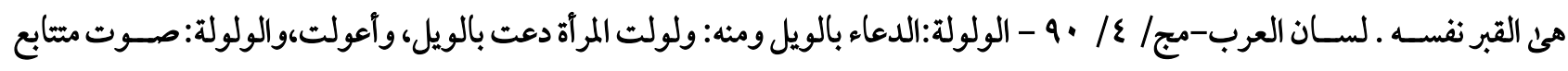

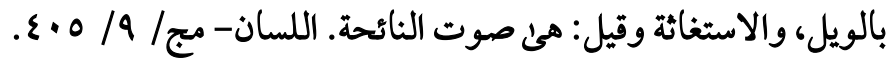


بهه، فهو يدفعهم جماعات، كل جماعة تلو أختها إلى بيوت هئ القبور بعينها، أما إذا أســد الفعل إلى المستعمر، فالسوق حقيقة، ويكون التعبير كناية عن تمام تمكن المستعمر منهم، فهو يدفعهم دفعا شديدا، و بقسوة تعكس

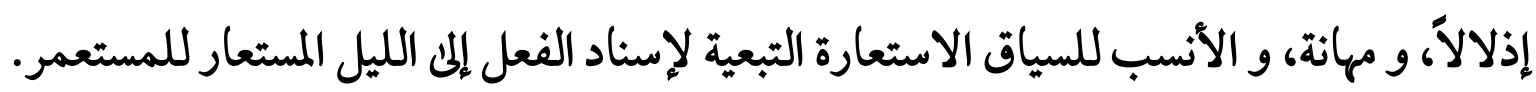
كما استعار الحفر - المقصود بها القبور في قوله: (إلى حفر مولولة الرجوم) - استعارة تصريية- لبيوتهم التي يدفعهم إليها الليل الطاغية، تلك البيوت التي تحولت قبورا، تصيح حجارتها مولولة عليهم، وهم يساقون

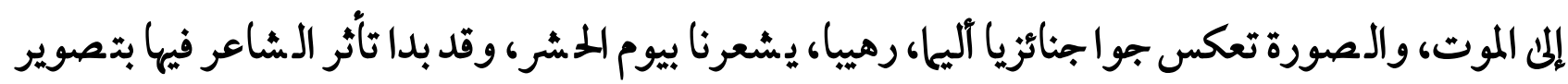

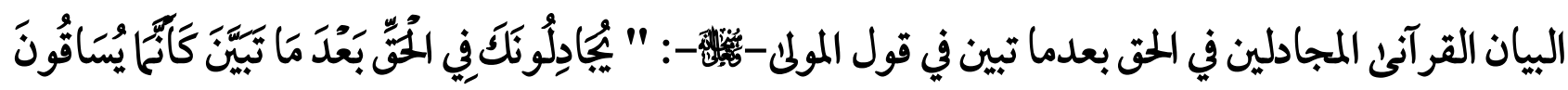

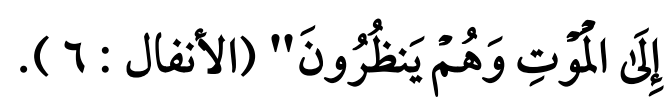
أضف إلى ذلك فإن مفردات الصورة كلها توحى بالتجبر، والطغيان، والقسوة التي لا ترحم ضعف من تدفعهم إلى تلك المفر، المولولة عليهم، دفعا شديدا، متجبرا، مـ ستمرا، فهو (يسوقههم- زمرا - إلى حفر - التي

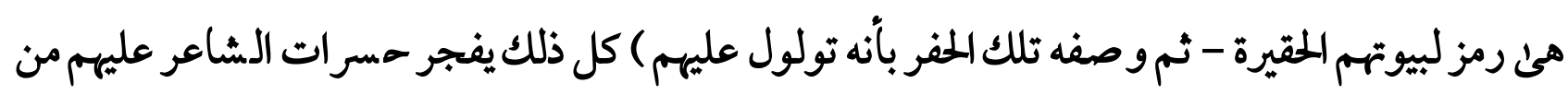
خلال تصوير استمرارية فعل هذا الليل الطاغية بهم، كما بدا في الاستعارة التبعية في الفعل (يسوقهم). والملاحظ هنا تكثيف التصـوير بالاسـتعارة، و كأنما يتوالد بعضـها من بعض، فالاسـتعارة في قوله:(ويسوقهم) تتوالد من الا ستعارة السابقة في قوله: (ينفض فوقهم) حيث تولد سوقهم إلمال حفر مولولة

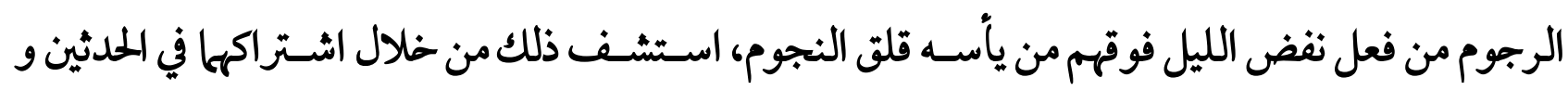

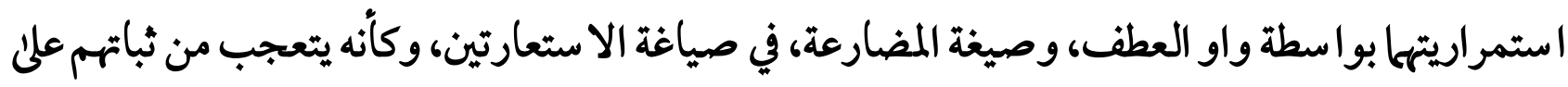
تلك الحال، مما يوحنى بتحسر الشاعر عليهم.

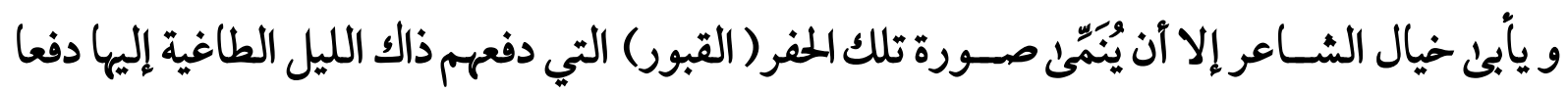

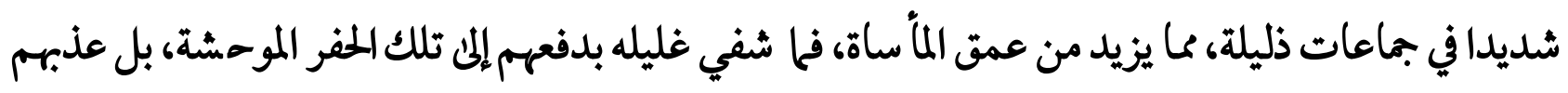
بكافة أنواع التعذيب- مادية ومعنوية - فكان التعذيب المادئ ماثلا في السوط يرفل حول تلك المفر الموحشة، والموت تحوم أنسره- في ساحة هذه المعركة المتخيلة، غير المتكافئة- تتظظر شبع بطونها من جمثهري: 


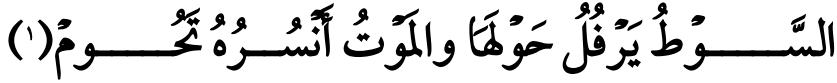

وجاءت الاستعارة التبعية في الفعل هنا في مو ضعين في قوله: (يرفل حولما - أنسره تحوم) فعمقت من

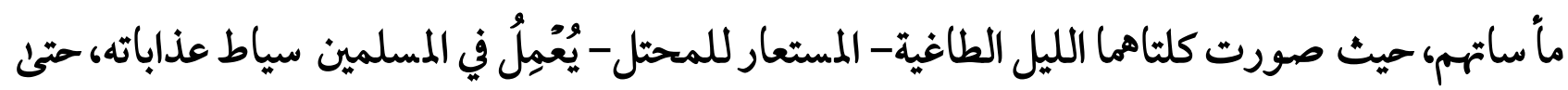
أشرفوا على الموت، و أنسره تتنظر شبع بطونها من جثهم، يفعل ذلك وهو آمن، مطمئن تمام الاطمئنان، متيقن

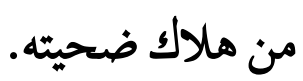

استعار الشاعر الفعل (يرفل) - استعارة تبعية-لحركة السوط الشديدة، اللاهية، وهئ تلهب ظهورهم، وصـاحبها على يقين أنها لن تجد من يردها، فهو يتلهن بهم كما يتلهئ الطفل بألعوبته، ما يعمق من مأسـاتهم، فيزيد من توجع الشاعر، وتحسره عليهم.

ولايخفي آن التبعية هي لازم المكنية، التي شبه فيها السوط بالإنسان الطاغية، يلهو بتعذيب ضحيته،

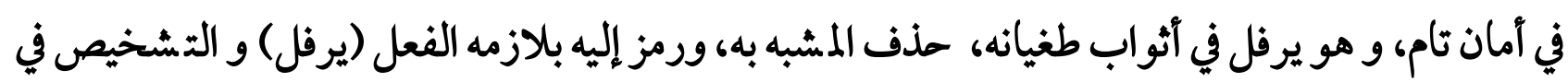
المكنية ليس مرادا هنا، بل المراد، والذئ يستدعيه السياق هئ الحركة في استعارة الفعل (يرفل) لأنها هئ التي

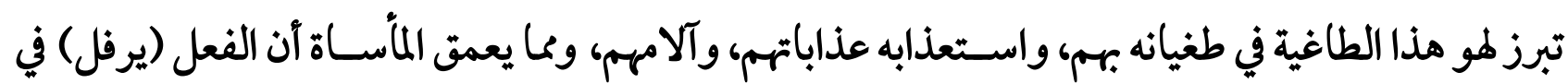
أصل ا ستعماله يدل على اللهو، والترف، و لا تتصف به إلا نفس منتشية، سعيدة به، يُستشعر ذلك من تكنية

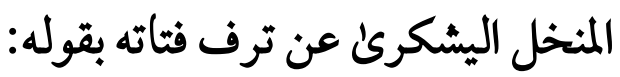

الكاعب الحسناء ترفل في الدمقس وفي الحرير(")

وا ستعارة هذا الفعل - في سياق التعذيب- لتلك المركة ال شديدة الطاغية، تلهب ظهور من دفعوا إلى تلك الحفر الحقيرة، التي تولول حجارتها عليهم من هول ما أصابهم، هنا تعد ا ستعارة تهمية، كالا ستعارة في

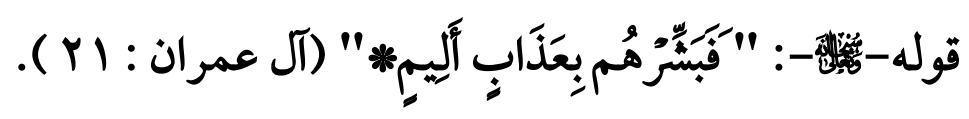

وتأتخى الا ستعارة الثانية في قوله: (و الموت أنسره تحوم) وقد تولدت من الأولى في قوله: (يرفل حولها) فكانت نتيجة لما، فالأولى أثـارت إلى أن تعذيبهم كان لموا، ورفاهة للمحتل، أو الطغيان، و أشـارت الثانية

1 - الرفل: جر الثوب وركضه بالرجل ورفل يرفل رفلاخرق باللباس وكل عمل. اللسان- مج/ \&/ ه.r.

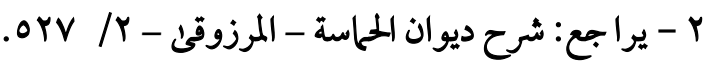


إلى أن ذلك التعذيب- من شدته، وطغيانه- كان السبب في إثرافهم على الملاك، فالاستعارة الثانية مسببة عن الأولم، وفيه ما يعكس شدة إحكام شاعرنا لبناء صوره الاستعارية، فجاءت ملائمة للمعنى المراد، وغرض الكلام.

وجعله للموت أنسر اتحوم حول أجسادهم المتهالكة، و التي آضحت خواء يعكس شدة التعذيب التي أشرفت بهم على الملاك، والاستعارة نقلت المعنوىن من جموده لتبث فيه حركة، وحياة، يختزلة مشاهد متعددة، و آلو انا من التعذيب قد طوتها بين ثناياها، يتخيلها المتلقى في صورة أذسر الموت متحفزة، يدفعها معالجة آلام الجوع، تنتظر هلاكهم لمل ؛ بطونها من جثهم. و الاستعارة تعتمد في بنائها على مخزون الشاعر من الصور التراثية للطير تتبع جيش الممدوح، واثقة من انتصاره، لتمتلمئ ساحة القتال بجثث أعدائه، تراها عند مسلم بن الوليد، و أبيل تمام، وغيرهما، كقول مسلم: قد عوَّد الطير عادات وثقن بها*فهن يتبعهن في كل مرتحل(') و على الرغم من اعتحاد الاستعارة على الصورة التراثية إلا آن الشاعر برع في تجديدها بها يلائم السياق، والمقام، حيث كانت الأذسر في الصورة التراثية حقيقية، وهنا جعلها الـشاعر للموت، فهلى متخيلة، كلا جعلها تحوم، وهذا موطن جودتها، لكونها صورت تحفز الأنسر لسد جوع بطونها من جثث المسلمين، الذين أثرفوا على الموت من شدة العذاب، و قد تكون الصورة كناية عن إشرافهم على الهلاك، فتعد من الكنايات المبنية على بجاز.

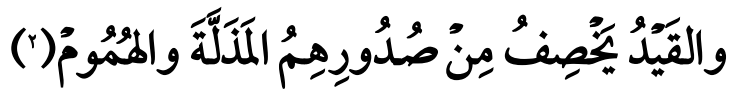

وأما عن التعذيب المعنوئ فجاء ماثلا في صـورة القيد يخصـف من صــدورهم المذلة، والمموم، وجاء التعبير بـــ(السوط) و(القيد) في صيغة الإفراد مع أنها في الواقع سياط، وقيود متعددة، فهناك سياط، وقيود

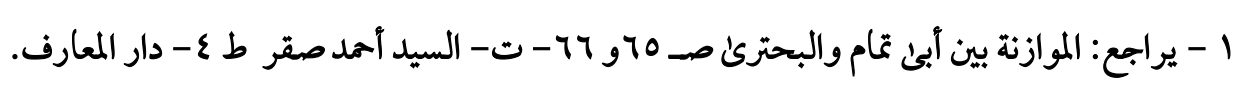

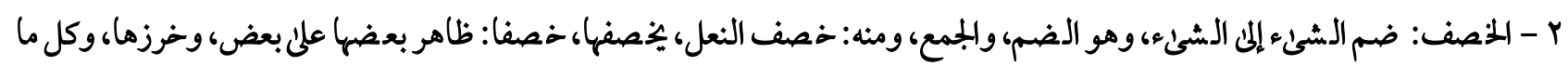

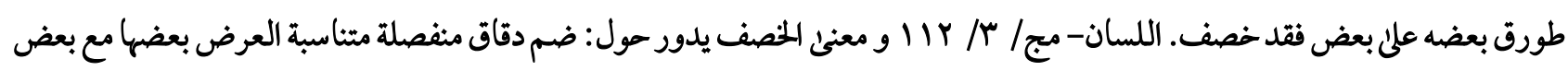

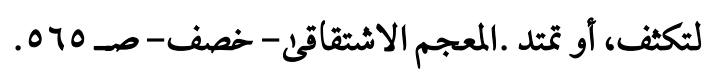


الجهل، والمرض، والفقر، والعجز، إلى آخر ما يفر ضه المحتل، أو الطاغية على الشعوب، عبر الشاعر بالإفراد وكأنه رأى سوطا بألف سوط، و قيدا بألف قيد في إمكام السيطرة عليهه، و إرهاب نفوسهم.

كا جاء كل منهها معرفا بــ(أل) ليفيد شهرة كلِ، وذيوع أمره في هذا المعنى أىل: السوط المعروف بإذلال النفوس، و القيد المشـهور بقهرها، ليبرز إمكام سـيطرة الليل الطاغية عليهم، وإرهاب نفوسـهم، ما يعمق المأ ساة، إضافة إلى ما يفيد إفرادهما من ا ستهانته بهم، وأن تشتيت نفو سهم لا يجوجه إلى ا ستعحال الكثير من الأسلحة، مما يستدعلى تحسر الشاعر عليهم.

و إسناد فعل الخصف إلى (المذلة، والمموم) وهما معنويان، قد يوهم التصوير بالا ستعارة المكنية، التي ثــحست القيد، لكن متابعة السـياق تؤيد أنها غير مرادة هنا، لأن مبنى الكلام على تصـوير قسـوة الفعل، وفظاعته، فالتبعية أولنه، لملاءمتها السياق، وغرض الكلام. هذا وقد جاءت تعدية الفعل(يخصـف) بـــ(من) دون (في) فقال: (يخصـف من صـدورهم) ملائمة للموقف، وللسـياق، لإفادة أن صـدورهم من شـدة ما ذاقوه من ألوان عذاب ذاك الليل الطاغية أصـبحت مسـتودعا لألوان المذلة، وأنواع المموم، تفيض من داخلها إلى خارجها، بمعنى : أنه من أراد الاغتراف من بئر المذلة، والمموم، فليغترف، فهذا مستقرها، فالقيد يغترف منها، و يجمعها إلى الخارج، وهى صورة مبتكرة تبرز قمة معاناتهم من عذاب المستعمر لفم. و وذا الاسـتعهال مختلف فيه، فالكوفيون، و من لف لفهم يرون: أنه من باب نيابة حروف الجر مناب بعضها، فـ (من) هنا تكون بمعنى (في)(') أما البصريون فقد مالوا إلى التأويل، و عدوه استعالا بجازيا حينا، كما قالوا بالتضمين حينا آخر، و هو: إثراب الفعل معنى غيره، أو تعديته بحرف جر غير المسـتعمل فيه، واختلف العلماء بداية من (ابن جنى) إلى القول بحقيقة الفعل، أو بجازه، وكون هذا الاستعحال قياس، آم سهاع، حتى امتد الاختلاف في العصر الحديث بين المجمع المصرئ، حين أخذ برأئ البصريين، فقال: إن التضمين بجاز بششروط، بينها أخذ المجمع الأردنى 
برأئ الكوفيين أنه استعهال للأفعال، أو الحروف في معنى بعضها حقيقة(') و لميوقفنا هذا الاختلاف علئ سر استعال الحرف مكان غيره، فالتضمين بهذا "يصرف الاهتحام عن تدبر أسرار الحروف، و هو عاجز عن الوفاء بأغراض النظم، و دواعيه، و ليس أكثر من محاولة تصسحيح

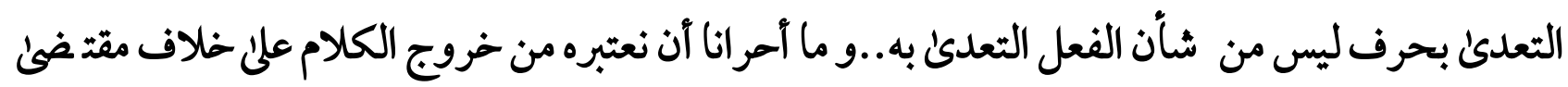
الظاهر ..و علينا أن نبحث عن دواعيه، وأغراضه" (†)

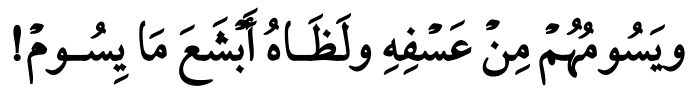

و يتابع الشاعر تصوير ما يذيقهم المستعمر من ألوان العذاب بطريق الإجمال، عاطفا البيت على ما قبله بالواو في إشارة إلى ترابط صور العذاب، و تسلسلها، فقال: (و يسومهم من عسفه و لظاه) موظفا الإبهام في التعبير بالاسم الموصول (ما يسوم!) دون ذكر الصلة، لتهويل، و تفظيع حالفم، وأن ما يذيقهم المستعمر من

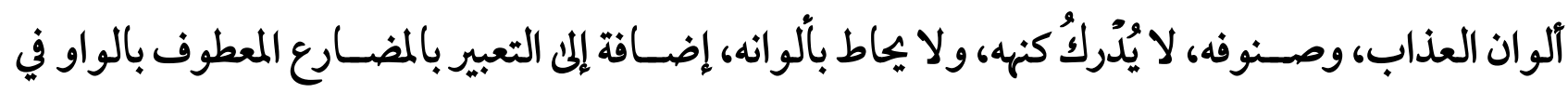
قوله:(ويسومهم) دلالة على استمرارية تعذيبه لهم بكل آلوان العذاب، والعجيب أنهم لا ينبسون ببنت شفة،

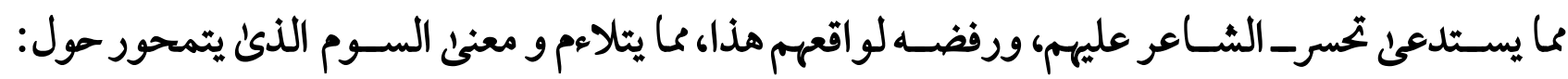
"امتداد بقاء، أو مرور، وذهاب في حيز، بلا حد، ومنه سـامه ذلا، أولاه إياه، كما نقول : أذاقه (وهو من بجاز

\section{الرعى، فينبغى آن يلحظ فيه الدوام، كأنه غذاء)"(")}

و اختيار الثـاعر لمادة الفعل - بجا فيها من الامتداد، والذهاب في حيز بلا حد- ملاحظ فيه هذا المعنى من امتدادعذاب المستعمر للمسلمين، وتواصله، با يتلاءم و التهويل و التفخيمفي قوله:(أبشع ما يسوم!!) فهو تهويل

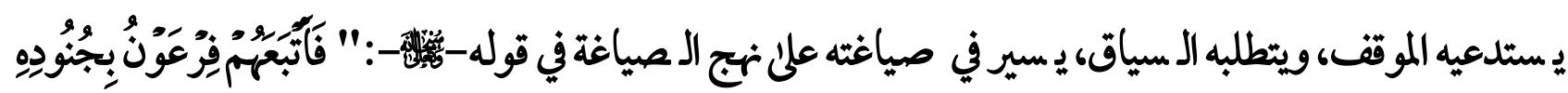

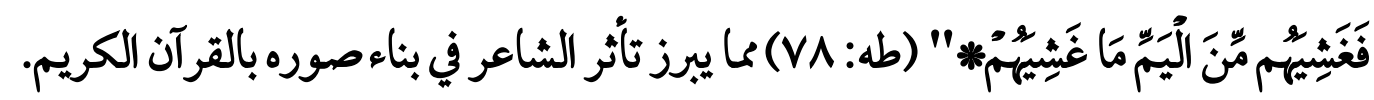

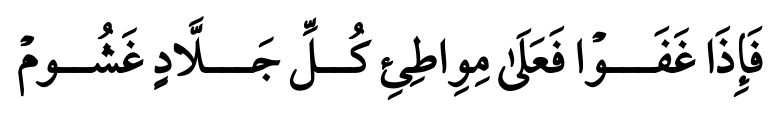

$$
\begin{aligned}
& 1 \text { - من أسرار حروف الجر فن الذكر المكيم- د/ محمد الأمين الخضرئ-صـ Y ا و ما بعدها - بتصرف. }
\end{aligned}
$$

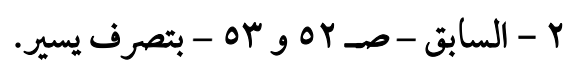

$$
\begin{aligned}
& \text { r - المعجم الاشتقاقئ لألفاظ القرآن الكريم- - م/ محمد حسن جبل - سوم - صـ } 79 \text { - } 1 .
\end{aligned}
$$




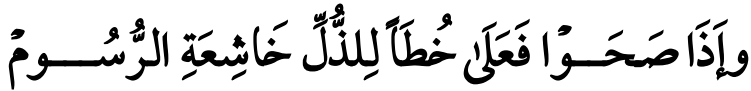

وإذا كانت الصياغة المعبرة عن هول ما يلاقون من عذابات المستعمر قدجاءت مبهمة في البيت السابق،

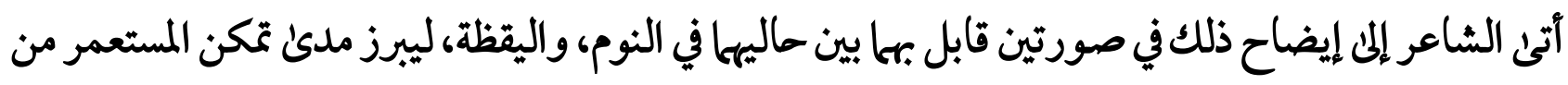
إرهابهم، و تشتيت فكرهم ليل نهار، وكان للصياغة في صورة الإيضاح بعد الإبهام أثرها في نفوس المتلقين، ذلك "لأن المعنى إذا ألقى على سبيل الإجمال، والإبهام تشوفت نفس السامع إلى معرفته علئ سبيل التفصيل،

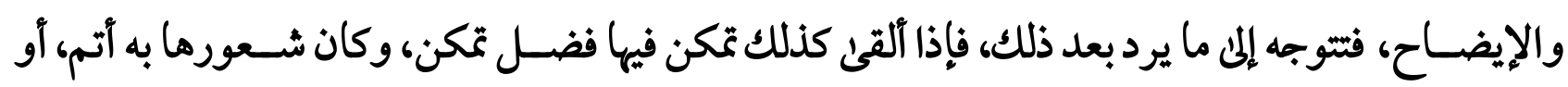

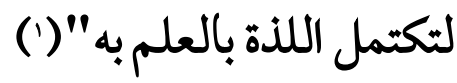
وجاء البيت الأول معطوفا على سابقه بـــ(الفاء) (فإذا غفوا) والثانئ معطوفا على هذا بــ(الواو) في صياغة مصدرة بأداة الشرط (إذا) التي كررت لتبرز تلاحم البناء في البيتين، فكانت رابطاً " يقوم علن إبراز

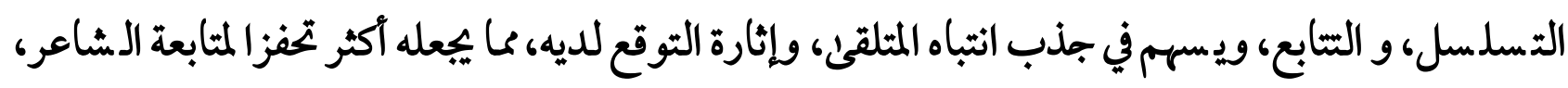

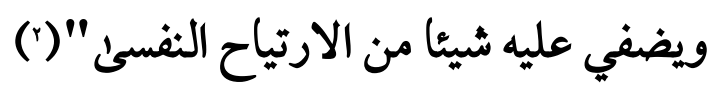
و (إذا) ظرف لما يسـتقبل من الزمان، تفيد "اسـتحضــار حدث ليس موجودا الآن، لكنه سـيقع في

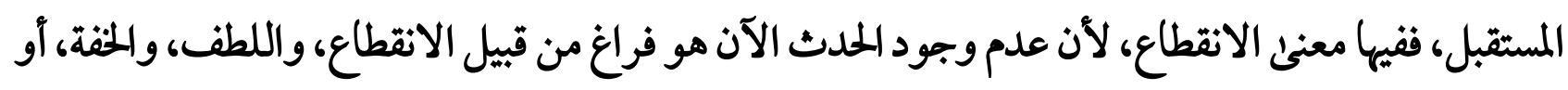

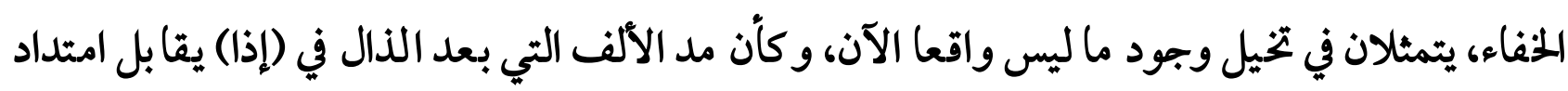
فرصة الوقوع "(r)

وهذا المعنى يشـير إلى تخيلهم أنهم يغفون، مع أن واقعهم غير ذلك، كما يشـير إلى أنهم حتىل لو رغبوافي

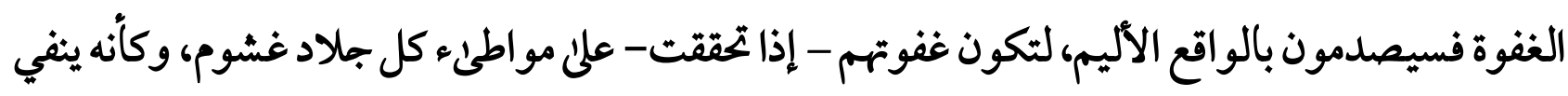

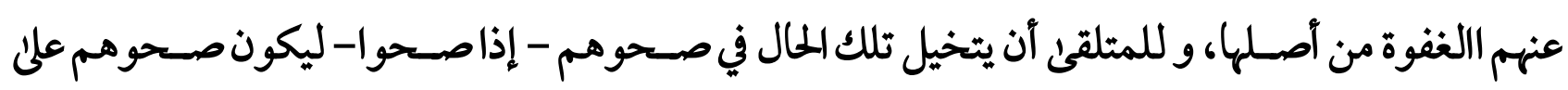

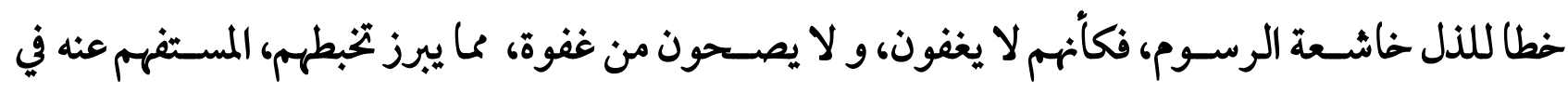

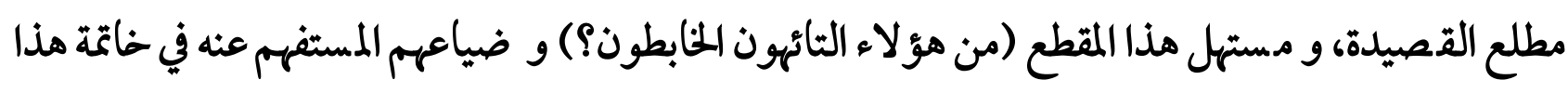

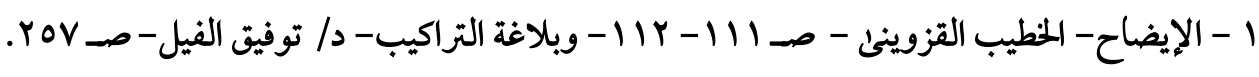

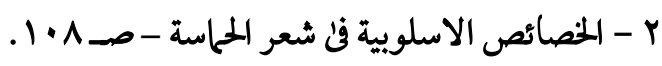

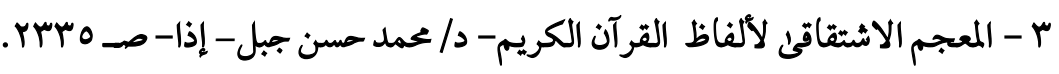


المقطع (من هؤلاء الضاتعون؟) و بالتالمي يعكس تحسر الشاعر على حالفم تلك من خلال الاستفهام الإنكارىن. هذا، و صـياغة الصــورتين من خلال المقابلة بين حاليها في الإغفاء، والصسحو تعكس فظاعة ما فعله المستعمر بهم من جانب، كما تبرز المفارقة المتولدة من علاقة التضاد بين الصورتين من جانب آخر، فصورة المسـتعمر تفيد جبروتا لا حد له، يتمثل في غفوتهم -إذا غفوا- على آثار ما وطئه في أجسـادهم، وصــورة المسلمين تفيد ضعفا، و خنوعا، لا حد لملما، فهم ي صحون - إذا صحو - على خطا منكرة، أ سندها الـشاعر

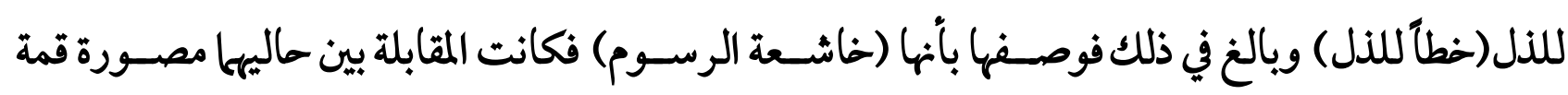
مأساتهم، و فظاعة ضياعهم. كما آن تعدية الفعلين بـــ(على) (غفوا على - وصحوا على) في الحالين تسلبهم الإرادة الفاعلة، و تصور أن المستعمر مستعلِ عليهم في حالمى غفوهم، وصحوهم، متمكن من تقليبهم في ألوان العذاب كيفما شاء، وفي كل حال، و يؤيد هذا مقابلة الاستعلاء المتجبر المستشف من صيغتى المبالغة (جلاد غشوم) بالمنوع المستشف من (خطا للذل خاشعة الرسوم) تلك الخطا المضافة للذل، والموصوفة بأنها خاشعة الرسوم بطريق الكناية عن نسبة، حيث أسند الحشوع لرسوم خطاهم المضافة للذل، و المراد خشوع أصحابها. والكناية مبنية على مجاز في قوله:(خطا للذل) حيث شبه الذل بأناس ضعاف خانعين، ثم حذف المشبه به، ورمز إليه بلازمه مضـافا إلى المشـبه، ليبرز تخبط خطاهم، و جاءت الكناية لتؤكد خشـوع أصسحابها، فلم تنسبه إليهم، بل نسبته إلى خطاهم المضافة إلى الذل، ليكون مَعْبَرَاً إلى نسبته إليهم.(') هذا، وبين صورة (صحوهم علن خطا للذل خاشعة الرسوم) في خاتمة المقطع، وصورة (خط) أبصارهم التي أصيبت بمرض العشى) في مطلعه تدور الأحداث، وتتسلسل المعانى في صياغة محكمة، يرد فيها ختام المقطع على مطلعه ردا جميلا، يلائم غرض الكلام، والسـياق، أضــف إلى ذلك مقابلة الاسـتفهام في المطلع بالاسـتفهام في خاتمة المقطع، لإدراك قيمة هذه الظاهرة البلاغية في ترابط صـياغة الكلام، وإحكام بنائه، بها يلائم أغراضه، ومعانيه.

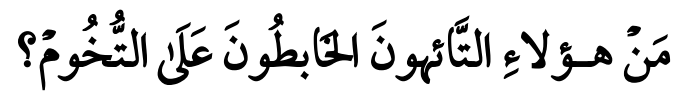

1 - يراجع: تحليل د/ عحمد أبو موسئ لأمثال هذه الصور في: التصوير البيانيصـ جه و ما بعدها. 


\section{$r T$

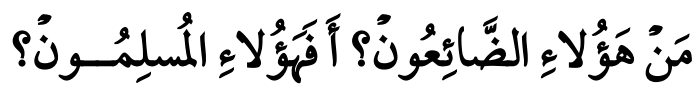

كما أن المستفهم عنه في خاتمة المقطع (الضائعون) جاء ملائم) لمنوعهم، و ثباتهم على تلقئ ضربات الليل

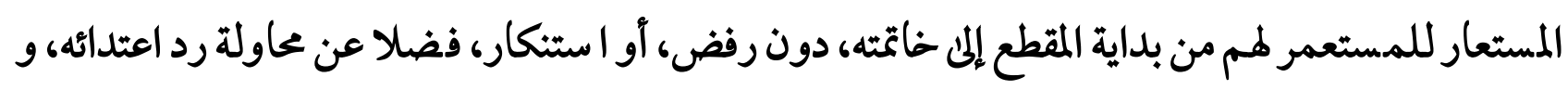
كلها صور ضياع أثارت الشاعر فاستفهم منكراً، متحسر أ مرة، و متعجبا آخرئ.

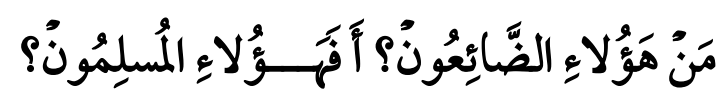

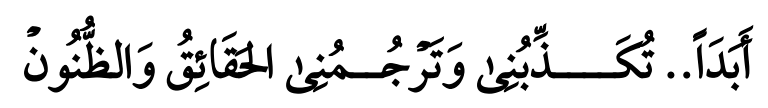

و المقاطع لي ست مفحولة عن بع ضها، بل هئ مفصولة لفظا، مو صولة معنخ، فالبيت يصلح خاتمة

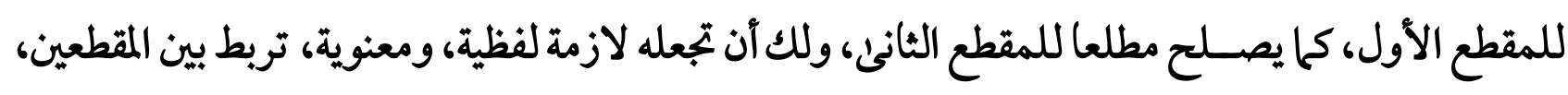

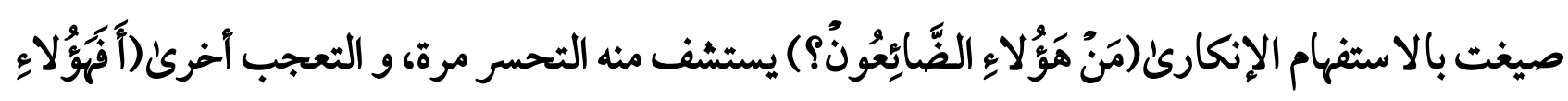

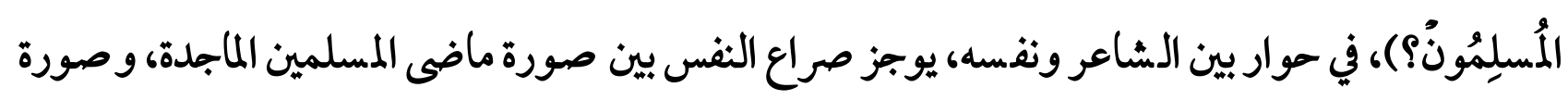
ماضرهم التائهة الذليلة الضائعة. 


\section{المبحث الثالث: المباث \\ التعجب من حال المسلهـين و يِّيمينهم القرآن الكريهم}

و هذا المبحث يعالج و جوه بلاغة المقطع الثاني في الق صيدة، و قدصسيخ البيتان السـابقان في آ سلوب اللف والنشر المرتب، حيث أتى بفعلين على الترتيب (تكذبنى وترجمنى ..) ثم أعطى لكل منها فاعله المناسب على الترتيب (الحقائق والظنون) من غير تعيين، ثقة بأن الســامع يرد كلا منها إلى ما هو له، و هو تعريف

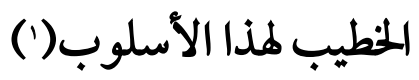
و كان لمذا الأ سلوب دوره كأداة ربط تحكم بناء القصيدة، إضافة إلى دوره في مو سيقى الأداء في هذا

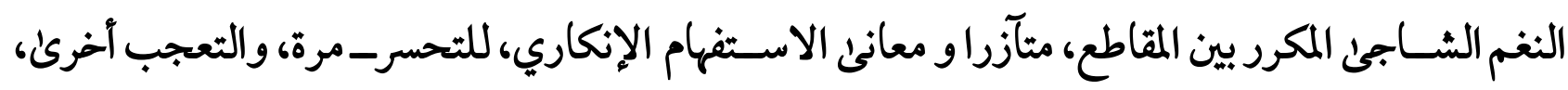
والحيرة ثالثة. ويؤيد هذا أن الأ سلوب بحث بمسميات تتصل بالمعاني، كـــــ (التفسير، أو التبيين، أو صحة الثفير، و بحثه ابن الأثير في باب تناسب المعاني (ترتيب الثفسير)(') وينتقل الشاعر من أسلوب الاستفهام التعجبى (أفهوٌ لاء المسلمون؟) إلى أسلوب اللف والنشر المصدر بلفظة (أبدا) التي تتآزر مع الا ستفهام في إنكار واقع المسلمين، والتعجب من حالهم، ثم إلى ا ستفهام تعجبئ آخر (وكيف؟) و كأنه لا يصدق ما هو جاثم على صدره من تيه المسلمين، وتخبطهم، وذلهم، من خلال حواره مع نفسه، فيرد عليها بها ييلن صورتهم الملاجدة حينها كانوا يعيشون في آيات القرآن الكريم، وييون بها، متعجبا من وصولفم إلى تلك الحال (وفي يمينهم كتاب لا يهون!!) أئ: لا يهون حامله، فيقول:

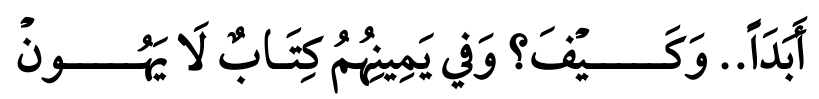

فسبب التعجب المستشف من أ سلوب الا ستفهام (..وكيف؟) أن (في يمينهم كتاب لا يهون) وجاءت صياغة الكلام بالا ستعارة المكنية، التي شبه فيها القرآن الكريم بالسيف الماضى، أو السلاح الفاتك، يحمله

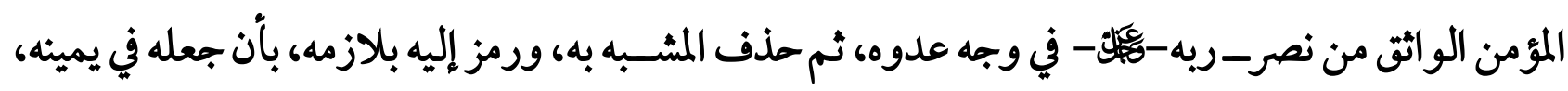

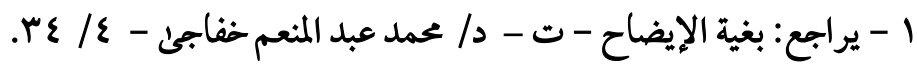

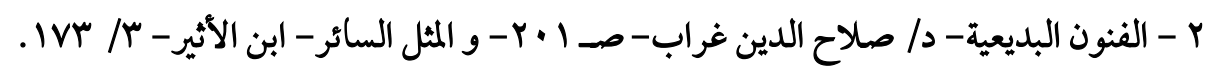


متمكنا منه تمام التمكن، والغرض إبراز تمكن معانى الكتاب العزيز من نفوسههم، حتى تشــبعت بها قلوبهم، كما يتمكن السيف في يمين حامله، ثقة في نصر الله، واعتزازا بنفسه التي ما آعزما الله-وَّلئ- إلا بالإسلام. و في الكلام إيياز بحذف فاعل الفعل المنفي:(لايهون) يدل على تعظيم الكتاب الكريم، و يشير إلى عز

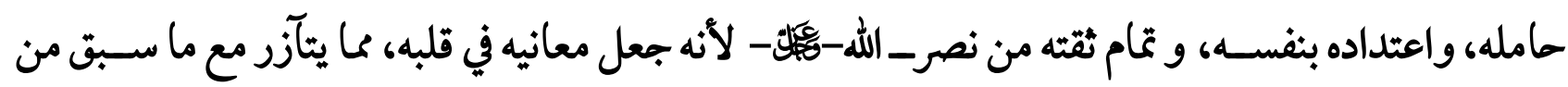
أسـاليب بلاغية تبرز تحميس الشـاعر نفوس المســمين، وإلماب مشـاعرهم، للوقوف في وجه كل مسـتعمر غادر، غاشم، مها كانت سطوته. وفي تعبيره بـ (أبدا) وتكريرها ما يفيد إصرار الشاعر علنى إلهاب مشاعرهم، واستفزازهم للخروج من واقعهم هذا، لأنها نفي لصورة المسلمين المتعجب منها في الاستفهام السابق(أ فهو لاء المسلمون؟) بمعنى أن هذه الصـورة الخانعة الذليلة لن تكون للمســلمين، بها يجعل هذه اللفظة، وتكرارها في هذا الموضـع مؤازرا للاستفهام التعجبل في البيتين (وكيف؟ وفي يمينهم) (وكيف؟ ودون سطوته) فـ "(أبدا) من الألفاظ الملازمة للنفي، وهئ ظرف زمان لاستغراق المستقبل... و هي تفيد الدوام بلا حدود"( )

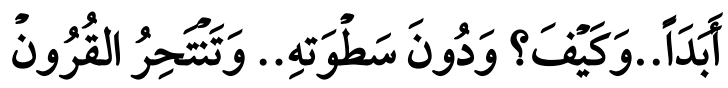

ثم يكرر الرد على نفسـه بالصـياغة نفسها بأسـلوب النفي (أبدا) يتبعه أسـلوب الاسـتفهام التعجبل (وكيف؟) وقوله (ودون سطوته) ترشيح للاستعارة السابقة في قوله:(و في يمينهم كتاب لايهون) يؤكد فعل القرآن الكريم في أصحابه المسلمين، فهو أقوئ سلاح لايهون أصحابه، ومتبعوا هديه. وفي الأ سلوب إيياز بحذف جملة ا ستشف من طريقة كتابة البيت ال شعرئ، حيث أ ضاف نقطا بعد قوله: (ودون سطوته..) وآتى بحرف العطف الواو في الجملة بعدها، فقال: (و تنتحر القرون) فدل ذلك علئ أن الجمملة الثانية معطوفة على جملة محذوفة قبلها، على تقدير: و دون سطوته تهلك الأمم(مثلا) وتتتحر القرون، وهذه طريقة في كتابة الإبداع الشعرئ تستوقف خيال المتلقى لتمنحه فر صة السباحة في تخيل عظم المأ ساة، وفظاعتها، إضـافة إلى تخيل المخذوف، ومحاولة تقديره، وبيان أن حذفه أبلغ من ذكرهلو ذكر، لأن الحذف هـ يسمح للنفس آن تسبح في تخيله كل مسبح، كما قال علماؤنا. 
ثم يسـتطرد الثـاعر - وهو ذو بيان سـاحر في الاسـتطر اد(') الذئ يعد خاصـة من خصـائص بلاغة القصيدة- وكأن الأو صاف يتوالد بعضها من بعض، في تسلسل عجيب، فيصف فعل الكتاب الكريم في إبادة العتاة، و هلاك المتجبرين، في مقابلة بين هذه الصصورة، و صورة فعله في قلوب المسلمين ونفو سهم في قوله: (وفي يمينهم كتاب لا يهون) و ومن خلال المفارقة بين الصورتين يتجلي تعجب الشاعر، وإنكاره تخبط المسلمين، وتيههم، وذلفم، ما يجعل أ سلوب الا ستفهام مفجرا للمعانى، ولصور البلاغة في كل مقطع، بل في القصيدة كلها، فحا من صورة بلاغية إلا وتراها تتصل بنسب إليه، فيقول:

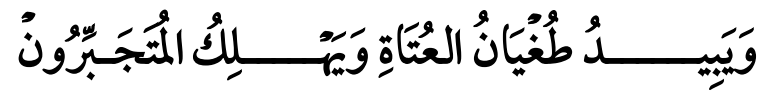

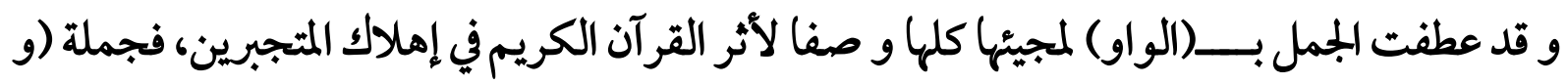
يبيد طغيان العتاة) معطوفة على جملة(و تنتحر القرون) كما آن هذه الجملة معطوفة على جملة (أبدا و كيف؟ و دون سطوته) قبلها، التي لا تنفصل عن أسلوب الاستفهام التعجبى قبلها، و المسبوقة بلفظة (أبدا) و العطف بالواو يسلك الجمل كلها في حيز النفي بــــ(أبدا) و التعجب المستشف من الا ستفهام ليصور نفيه أن تكون صورة المسلمين كحا سبق، و كيف تكون كذلك و آثر القرآن الكريم في إبادة الطغاة، و إهلاك المتجبرين ثابت مقرر في اعتراف الغاشمين أنفسهم بسطوته، و سلطانه، كحا أنه واضح ملموس لكل ذئ عينين، بل و مستمر إلى قيام الساعة، هذا الاستمرار المستفاد من صيغة المضارعة في الجمل كلها. هذا و قد صيغت الجمل بالا ستعارة التبعية في الفعل، ففي قوله: ( وتنتحر القرون) ا ستعارة تبعية في الفعل(تتحر) صورت يأس القرون- بناء على تشخيصها- أمام سطوة القرآن على أعداء الإسلام بالانتحار، و هو إنهاء الحياة يأسا، واشتق منه الفعل (تنتحر) لـــ(تنهي الحمياة) و منحه الاستمرارية، فكل قرن يتلو سابقه في الانتحار إلى قيام الساعة.

و في قوله:(و يبيد طغيان العتاة) استعار (يبيد) ليكسر-صـاحبه نفسـياً، لأن الطغيان قد يزال بموت صـاحبه، وقد يزال قسرــاً بإرغام صـاحبه على تركه- و هو المراد هنا- ليبرز آثر القرآن الكريم في انكســار

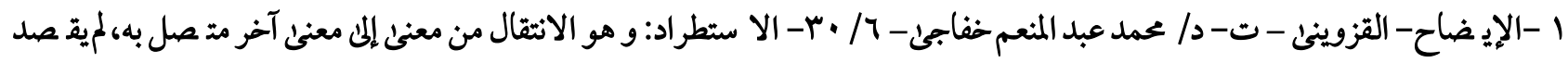
بذكر الأول الثوسل إلى ذكر الثاني، و قد يكون الثانئ مقصودا، و يذكر الأول ليصل إليه. 
صاحب الطغيان، فاستعار الإبادة لانكساره قسرا، واشتق منها الفعل (يبيد) علئ سبيل التبعية، و جاء الفعل مبنيا للمعلوم فوقعت الصـفات السـابقة فاعلا، أما في قوله:(و يهّهَك المتجبرون) فقد بنى الفعل للمجههول فوقعت الصفة نائبا عن الفاعل، فأشعرت بأنهم يهلكون من ذات أنفسهم من شدة سلطان القرآن الكريم، و قهره لنفوسهم.

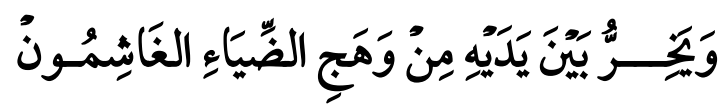

الخزور: السـقوط، و بين يديه ألى: أمام سـطوته، و ســلطانه، و المعنى آن الغاشـمون يسـقطون أمام سطوته، و سلطانه من وهج ضيائه، الذئ يعشى أبصارهم، و يستهلك قواهم فلا يملكون لـسلطانه عليهم دفعا، وقد استعير الفعل (يَرَّر) ليذهب منعتهم، و قوتهم على سبيل التبعية، التي خيلت إلينا أن سلطان القرآن الكريم عليهم قد حولهم آثباحاً، قد عدمت قواها، فسقطت. نسق تتابع الصفات بلا عاطف:

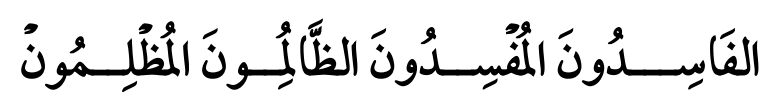

ثم يسـتطرد في بيان أثر القرآن الكريم في إهلاك أعداء الإســلام على الرغم من عتوهم، و تجبرهم، و غشمهم، فتتابعت الصفات بلا عاطف في هذا النسق- و هو خاصة بارزة في بلاغة القصيدة- كأنما تولدت من صفتهم الأخيرة (الغا شمون) ومن الواضح تأثر الشاعر في هذا النسق بأساليب القرآن الكريم في آيات

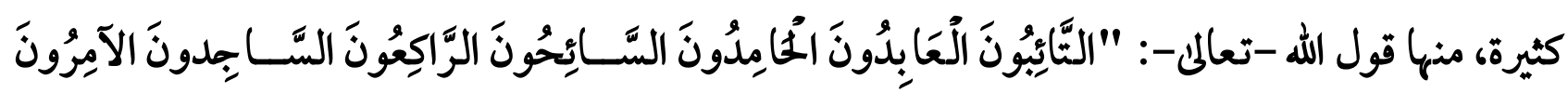

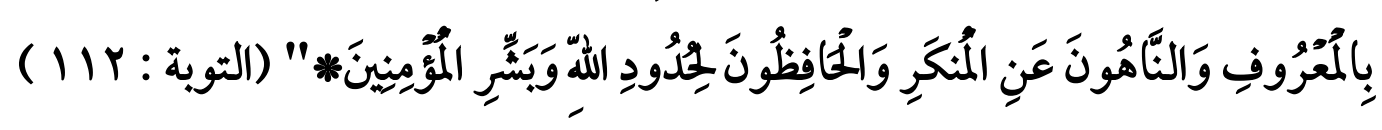
ففي الآية الكريمة تركت(الواو) في الصفات من الأولى إلى السادسة، أما الصفات الثلاث بعدها فذكر

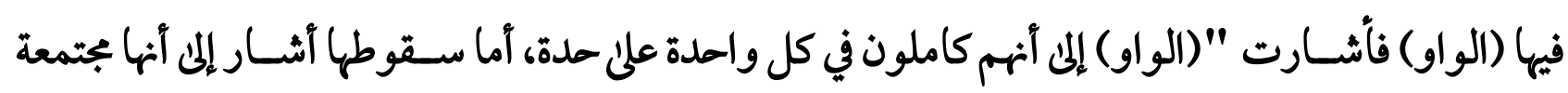

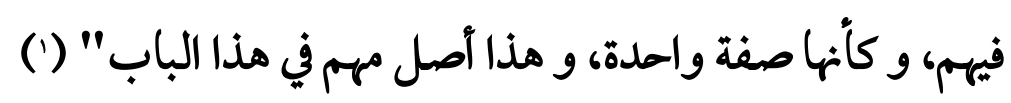
و لا يخفي آن تتابع الصـفات بلا عاطف في الآية الكريمة جاء لمدح المؤمنين، بينما جاء هنا لذم المستعمرين، وبيان جبروتهم، وظلمهم، وفسادهم، في سياق يصور قهر القرآن الكريم لكل الفاسدين الظالمين 
المتجبرين، مما يشير إلى أنهم عجنوا من هذه الصفات بجتمعة، و كأنها صفة واحدة.

وجاء التعبير عنهم في هذا المقام بصفاتهم في صورة ا سم الفاعل معرفة بــــ(آل) ليفيد ثباتهم علئ هذا الو صف، فهم العتاة الثابتون علئ العتو، وهم المتجبرون الثابتون على تجبرهم .. إلخ - لأن (أل) هنا إما للمح ال حفة، وإما بمعنى (الذئ) لدخولما على ا سم الفاعل، و أكثر النحاة على أنها مو صول ا سمى، فمعنى جاء

$$
\text { (') الضارب زيدا: جاء الذئ يضرب زيدا. () }
$$

وعليه، فمعنى (الفا سدون) أعا: الذين يف سدون أنف سهم، والمف سدون الذين يف سدون غيرهم.إلخ، ومعنى أنها تلمح الصفة: أنها تشير إلى صفة إفسادهم آنفسهم في (الفاسدين) و إلى صفة إفسادهم غيرهم في (المفسدين)...إلخ.

كحا جاء التعبير عنهم بصـيغة الجمع فأفاد أنهم- مع كثرتهم، واجتحاعهم، وكأنهم كتل عجنت من العتو، والتجبر، والغشــم، والفســـاد، والإفســاد، والظلم، والإظلام - أمام ســوة الكتاب العزيز، وقهره أعداء الإ سلام- يطيرون هباء، وي صيرون سدىن، كحاعبر علئ محمود طه في أحداث حرب 19 9 ام و التي حفزت محمود حسن إسـاعيل لنظم هذه القصيدة. حسن التخلص من الإجمال إلى التفصيل

ثم يخلص الشاعر من الإجمال إلى التفصيل - في نسق تتابع الصفات دون عاطف- فيقف مع صورتين يفصـل فيه| صــورة المحتل، وهو يصـب جام ظلمه، وتجبره علنى المسـلمين حين| تخلوا عن كتابهم الذئ طالمال نصروا بالتمسك به، والذئ كانوا على يقين من قهره أعداءهم، ليبرز الشاعر - من خلال الصورتين- المفارقة بين ظلم المعتدئ، وتجبره، و ضعف المسلمين، وخنوعهم، ما يستدعئ التحسر عليهم، وا ستفزاز مشاعرهم للنهوض: الصورة الأولى: وهئ صورة مبتكرة للظالمين، وهم مقيمون على شرب الدمع ممن في المجازر يصرخون، و قد جرت جملة (الشُاريون الدمع) على نسق تتابع الصفات بلا عاطف، وهئ واقعة موقع المفرد في صدارة الجملة، فحقها أن تجرئ على النسق نفسه، لتحقق إشارة الشاعر إلى أنهم عجنوا من تلك الصفات بجتمعة، و 1 - يراجع: (أل) فئ الكلام العربئ - همدئ الجبالئ - صـ باوعوه - بجلة جامعة الأزهر بغزة - المجلد السابع - العدد الأول - ع +. rم 


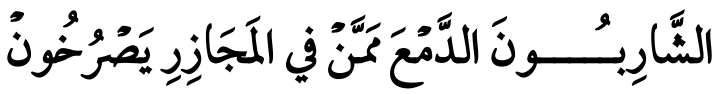

وللمتلقى أن يتأمل تلك الصورة الفظيعة، المرعبة، لأناس يشربون الدمع من أناس يبكون، ويصرخون من قسوة الألم فهم (في المجازر يصرخون) و تبدو فظاعة الصورة في أن من طرحوهم فيها هم الذين يشربون دمعهم، وصـورة شرب الدمع كصـورة مص الدماء، قد تكون كناية عن نهب الثروات، وتعذيب أصسحابها،

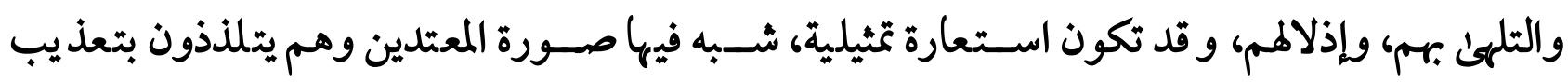
ضحاياهم، الذين تفيض دموعهم، وهم يصرخون من شدة العذاب، بصورة الشاريين الدمع من في المجازر يصرخون، ثم أجرئ الثانية على الأولى بعد ادعاء دخولما في جنس الثانية، وتنا سئ عملية التشبيه، على سبيل

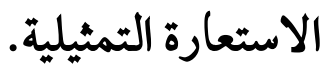

و الا ستعارة هنا خيلت لنا آن قوام حياة المعتدين هو التلذذبتعذيب ضحاياهم، فلا يشربون ماء يقيم

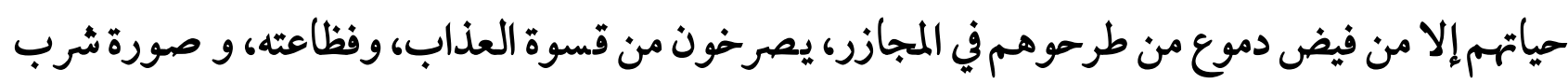

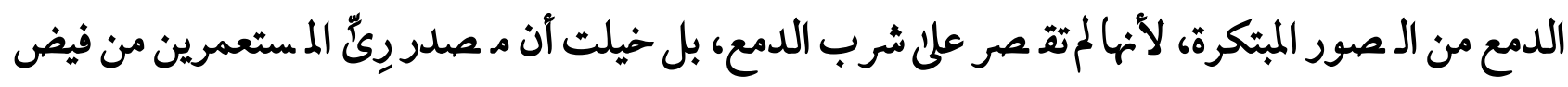

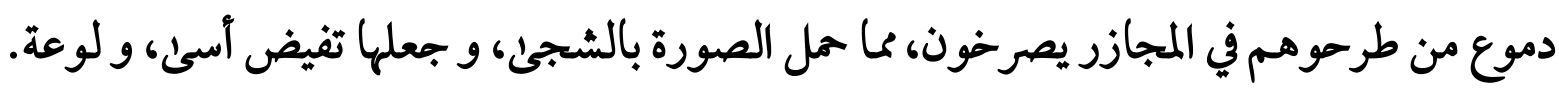
الصورة الثانية: وهئ صورة الظالمين المعتدين، وهم مقيمون على سوق الملق كقطعان البهائم، مسلوبئ الإرادة (ساجدة العيون) كناية عن المنوع، والذل، وهم كناية مؤكدة للتشبيه، ومقوية لمههومه، تتبعها كنايات

أخرئ كلها تفصيل لصورة المشبه به (مبهورة - منهورة بالسوط- تجهل ما يكون )

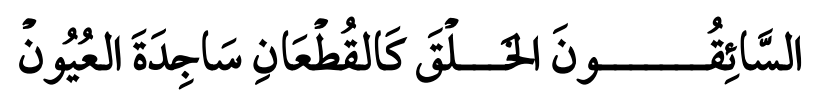

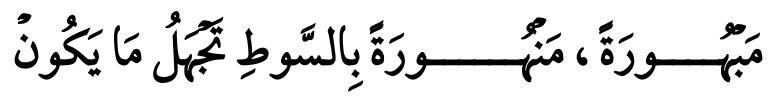

وقدجاءت الصياغة في صورة التشبيه المصدرئ، الذئ يقع فيه المشبه به مصدرا مبينا لنوع عامله، وتقدير التشـبيه: السـائقون الملق سـوقا كسـوق القطعان سـاجدة العيون، ليبرز نوع السـوق، وأن فيه من

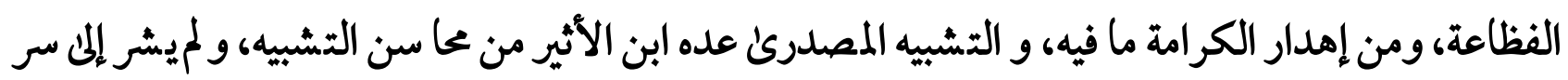

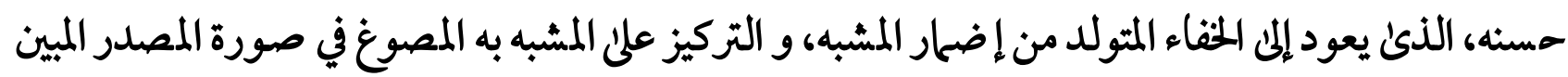


(') (لنوع عامله

هذا و جاءت أ ساليب الكناية مفصلة صورة المشبه به، و هئ و صف لحال المعتدئ عليهم (كالقطعان ساجدة العيون- مبهورة - منهورة ..إلخ) في الذسق نف سه، الذى صيغت فيه صفات المعتدين، وهو: تتابع الصــفات دون عاطف- في صــورة مقابلة لصــورتهم- لتشـير أن المعتدين كحا كانوا ثابتين على ظلمهم، وإظلامهم، وف سادهم، وإفسادهم، و عتوهم، و تجبرهم، و شهرتهم بذلك، وتتابع صفاتهم كأنها عجنوا من تلك الصفات، كان المعتدى' عليهم في المقابل كأنما عجنوا من صفات الذل، والمنوع، وسلب الإرادة، وغيرها، والثبات عليها المستشف من صيغة الا سمية، و مقابلة(قمة التجبر والعتو-وقمة الحنوع والذل) تبرز فظاعة الخطب، وعظم المصاب، مما يستدعى التعجب من حالفم، والإنكار لما، وبالتالى التحسر عليهم، واستفزازهم ل اللخروج منها.

و قد تتابعت الكنايات مفصلة صورة المشبه به ( السائقون الخلق كالقطعان) فكنى أولاً عن انكسار العيون نتيجة التعذيب، و قهر النفوس بسجودها (ساجدة العيون) و هذه الصورة خيلت أن للعيون سجودا، والسجود لا يكون لما، بل يكون لأصحابها، ثم كنى عن سلب إرادتهم، و ضعفهم بقوله:(مبهورة) و صف للخلق، أصله: "من البهر وهو: الغلبة وبهره يبهره بهرا قهره وعلاه وغلبه وبهرت فلانة الذساء غلبتهن حسنا

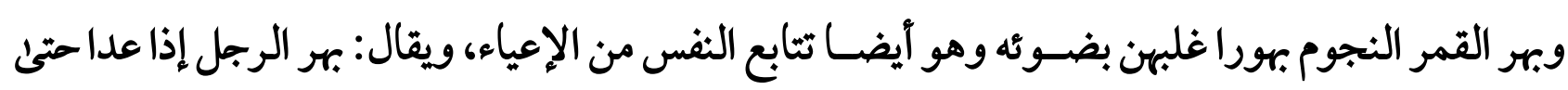
غلبه البهر وهو الربو فهو مبهور وبهير"(')

ثم كنى عن قهره نفوسهم بالنهر بالسوط ، و بجهلها سبب نهرها به، في قوله: (منهورة بالسوط، تجهل ما

$$
\begin{aligned}
& \text { يكون) "من النَّر، وهو الانتهار، والزجر، ونهر الرجل، ينهره نهرا، وانتهره: زجره" (r) }
\end{aligned}
$$

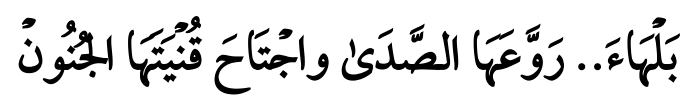

كا كنى عن حسن طويتهم بالبله، و هو: "الغفلة عن الشر، وآلا يحسنه، والمرآة بلهاء، وهى: الغِرٌّ التي

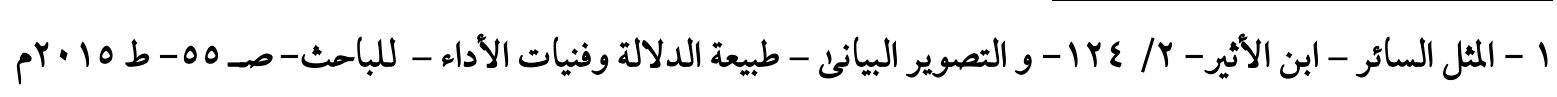

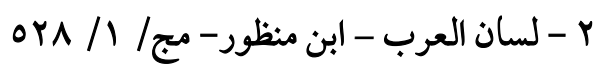

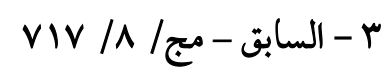


لا دهاء لها، والبلهاء من النساء: الكريمة، الغريرة، المغفلة، و الأبله: الرجل الأممق الذئ لا تمييز له"(() و يعمق الشاعر من صورة مسن طويتهم، في صفها بالفزع، و آن صدى الـصوت يوزع فكرها بددا

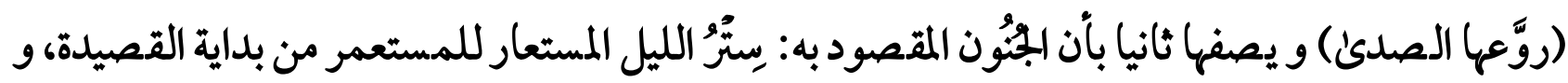

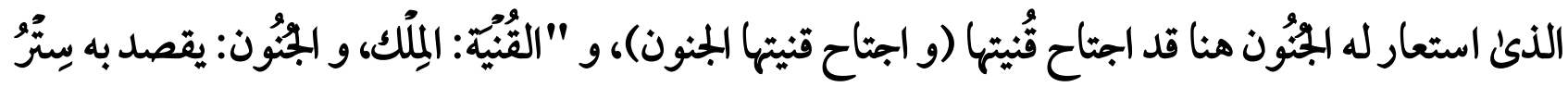

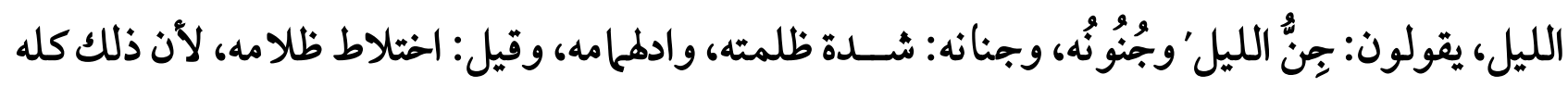

(r)" ساتر

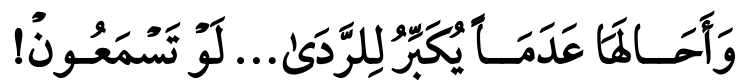

و يلاحظ التدرج في الصـفات في صـياغة الكناية الأخيرة (بلهاء) من الضـفف في البله، و ما يفيد من غفلة عما يجيك لفم المستعمر من شرور، إلى الأضعف في صورة الترويع من صدى الصوت، إلى الأشد ضعفا في صورة اجتياح الجنون- المقصود به ظلمة الليل - ملكها، إلى عدم يكبر للردئ في البيت التالى، و لذلكصح العطف بالواو، لأن غرض الكلام منصب على تنامئ الصور بهذا التدرج إلى الصورة الاستعارية(عدما يكبر للردى') التي هذ هدف شـاعرنا، ليكون كل هذا معبرا إلى اسـتفزاز نفوسههم في عجز البيت، وخاتمة المقطع الثانئ، في قوله: (لو تسمعون!)

هذا و فاضـت الصـورة بالسـخرية، والتهكم، إضـافة إلى جدتها، آرآيت عدما يكبر للردى؟ لقد رآينا اسـتعارة الموت للحيّّ غير الفاعل في حياة الناس، و هذا الضرـب من التصــوير عده الإمام عبد القاهر من تنزيل الوجود منزلة العدم، و عليه جرت اسـتعارة الموت لحياة الكافر قبل آن تشر-ق فيها آنوار الإيلان، في

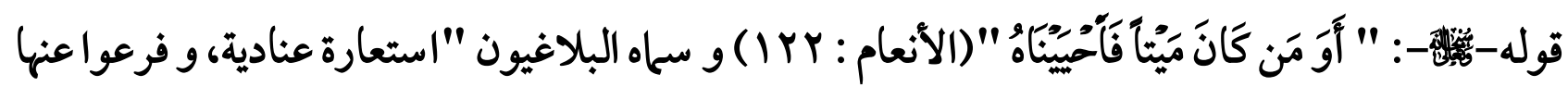
التهكمية، و التمليحية، و همل ما يستعار فيها الشىء لملا يناقضه على سبيل التهكم، و السخرية، أو التمليح، كما في قوله- 
$(') \cdot(\wedge \vee$

و شاعرنا لميكتف با ستعارة العدم لحياتهم التي صيرها المستعمر فاقدة مضمونها، بل جعل هذا العدم

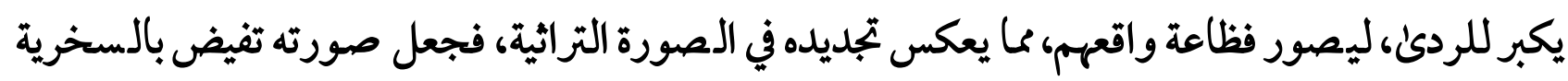

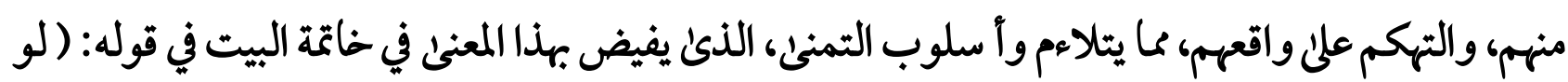
تسمعون !) كما يتلاءم وصياغة المستفهم عنه (الحانعون) مغايرا للمستفهم عنه في خاتمة المقطع السابق.

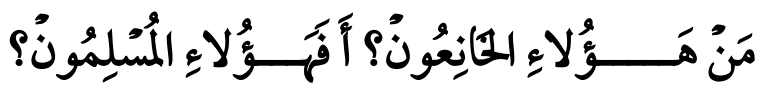

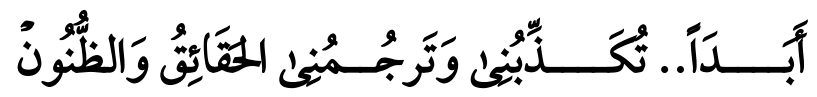

و يأتئ أسـلوب الاسـتفهام في خاتمة المقطع، و في النسـق نفسـه مصسوغاً من خلال لفظة (أبدا) يتبعها

أ سلوب اللف والنشر المرتب، ليعكس ما يمور في نفسه من إنكار مشبع بالتحسر مرة، و بالتعجب أخرىان، ليبرز عدم تصديقه أن هذه الصورة الخانعة الذليلة هئ صورة المسلمين، و نفيه آن تكون. 


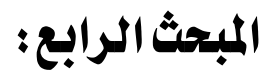

\section{موقف الشاعر من حال أمتـه}

و يتناول المبحث صور البلاغة في المقطع الثالث، فيصف الشاعر حاله أمام موقف أمته التائه، المتخبط، الخانع، ومعاناة نف سه بين رفض موقفهم هذا، ويين إه سا سه بـ ضياع جهده في ا ستفزازهم، فيتوجع وا صفا حاله: أنا منهم، أصابنى ما أصابهم، أدعوهم، وأ ستفزهم، لكن لا أحد يستجيب لدعوتى، لذا شبه صوته

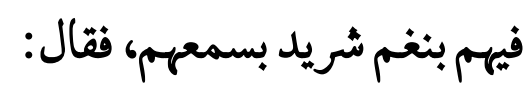

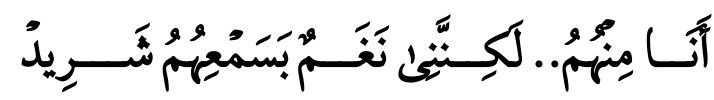

هذا، وجاءت صــاغة الكلام هنا في أسـلوب خبرئ يفيض حسرسة، ومرارة، جوابا عن سـؤال مقدر فحواه: لم تصف المسلمين بهذه الأوصاف المهينة؟ ألست واحدا منهم؟ لعلك تبالغ في الأمر تفظيعا، وتهويلاً، فكان جوابه في صورة شبه كمال الاتصال (أنا منهم) و ترجع بلاغة هذا اللون إلى أن "الجملة الأولى تحمل في ثناياها سؤالا تتشوف النفس إليه، و تتشوق إلى معرفته، فتجلى الثانية جوابا عن السؤال المقدر، و يسمىل هذا

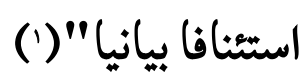

هذا وقد ملت جملة الجواب (أنا منهم) بأوجاع الشاعر، وآلامه، يتبعها الاستدراك بـ (لكن) مشيرا إلى معاناة نفسه لضعف تأثيره فيهم (لكننى نغم بسمعهم شريد) ثم تفصيل صورة المشبه به (نغم) بأوصاف هئ إيجاز بليغ، يصـف حاله، وحال أمته، يشـير إلى اثـتراكه معهم في الأدواء، والمصــائب، الذئ أبرزه الترابط المحكم بين أسلوب الخبر(أنا منهم) و الاستدراك (لكننى نغم بسمعهم شريد) " لكون المشبه به نكرة وقعت

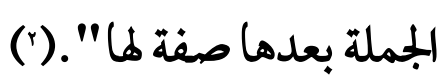

و قال (بسـمعهم) دون: في سـمعهم ليبرز أن كلامه ليس محط عنايتهم، ولا مناط اهتحامهم، وهو كناية عن ضعف تأثيره فيهم، فهو يتقلب بين نارين كانتا سبب إحساسه هذا، ما جعله يشبه دعوته فيهم بنغم شريد بسمعهم، أولاهما: تقييد الا ستعحار لحريته، فهو نغم قد (ربضت به الأصفاد) الأخرىن: عجز من يتقلبون في 
لظى عذاب المستعمر عن الدفاع عن أنفسهم، فضلا على الوقوف في وجهه (بل طحنته غمغمة العبيد).

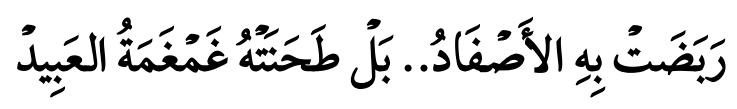

ثم يفصل صورة المشبه به، فيتبعها وصفين- بلا عاطف- مبرزا علة عجزه، مقررا آن نغمه قد(ريضت به الأ صفاد) وهو كناية عن ضعف تأثيره فيهم مبنية على بجاز خيَّل أن الأ صفاد قدلزقت بال شاعر، فقيدت حركته، فعل البهيمة تربض بالأرض، ثم ا ستعار الفعل (ربضت) للفعل (لزقت) ليصور ما يعانيه من قيود معنوية كثيرة، تبرز تفسير ضعف تأثيره في أمته( (') و قد منح المسموع (نغم) صفة المدرك بالبصر (الأصفاد) ليشعر بتقييد حريته في التعبير، فيها يعرف بـ " ترا سل الحواس، و معناه: و صف مدركات حا سة من الحواس بـصفات مدركات حا سة أخرىا، فتعطى للأثياء التي تدركها بحاسة السمع صفات المدركات التي تدركها بحاسة البصر..إلخ "(†) و هذا اللون له جذور في الأدب العربئ، إلا أنه ظهر حديثا كعنصر من عناصر تشكيل القصيدة الحديثة، تأثر فيه بعض الشعراء العرب بالرمزيين الفرنسيين، فاصطنعواصورا موغلة في الإبهام، و كان لمحمود حسن إسجاعيل إثارات واضحة في هذا اللون، بعد فيها عن الغلو في التصوير(r) ثم يستشعر آن هذه الصورة ليست السبب في شرود نغمه عن أ سلاعهم، فيضرب عنها إلى الصورة الثانية، ربها تكون آقدر على تصوير حاله معهم، فقال مستدركا بـ (بل) : (بل طحتته غمغمة العبيد)(') وهى كناية مبنية على ججاز متشابك، استعار العبيد للمسلمين الصامتين عن ظلم المستعمر، وآضاف لهم حركة إياءات، وكلام لا يبين، وهى الغمغمة، ثم ثــبه تلك الحركة بالطاحون، وحذف المثـبه به، ورمز إليه بلازمه مسندا إلى الضمير العائد على الشاعر، على سبيل الاستعارة المكنية، وهئ ليست مرادة هنا، بل المراد

1 - ربضـت الدابة والشـاة تربض ربضـا وريوضـا، وهو كالبروك للإبل ويقال: رجل ربضـة ومتربض: مقيم عاجز وربض الكبش: عجز عن

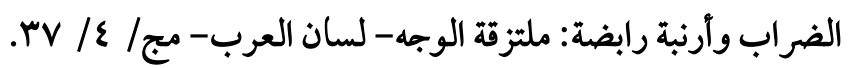

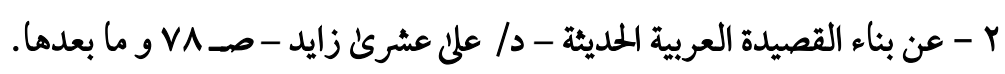

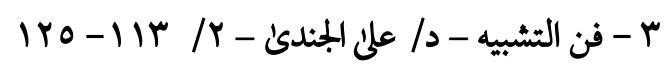

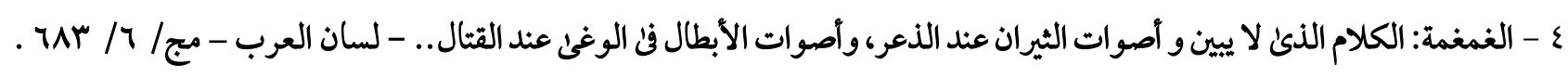


لازمها فعل الطحن مسندا إلى ضمير الشاعر، علئ سبيل التبعية، لأنه المصور لسبب عجز صوت الثاعر عن

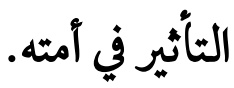

والصور المفصلة صورة المشبه به (نغم) - و منها هاتان الكنايتان-كلها كنايات مصورة ضعف تأثيره في استنهاض همم المسلمين، واستفزاز مشاعرهم للنهوض من كبوتهم، والكنايتان مبتكرتان، اخترعتها اخيلة الشاعر، وقدلعب تراسل الحواس في بلاغتها دورا بارزا، أرأيت نغخا ربضت به الأصفاد؟ أرأيت نغحا طحته غمغمة العبيد؟ الذين يرمز بهم إلى المسـلمين في تخبطهم، أرا ها صــورا مبتكرة، مؤدية للغرض، ملائمة للموقف، وسياق الكلام. هذا وقد لون الشاعر في توظيف أدوات العطف بين الجمل في تفصيل صورة المشبه به (نغم) فأ سقط واو العطف بين جملة (بـسمعهم شريد) و جملة(ريضت به الأ صفاد) جامعا بين الو صفين، و كأنها في نفسه وصفا واحدا، ليبرز اشتراكه معهم في المسؤولية، و أضرب بـ (بل) (بل طحنته غمغمة العبيد) لينفي آن تكون صورة (ربضت به الأصفاد) هل سبب شرود نغمه بسمعهم، و عطف بالواو جملة (وجؤار شرق) على جملة

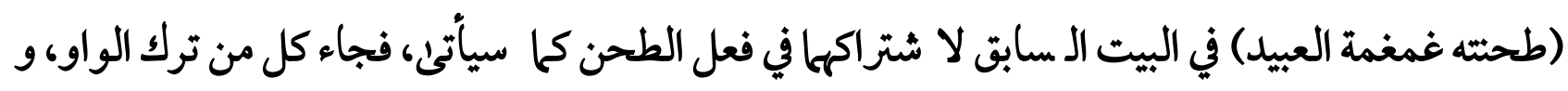
إثباتها، و العطف بـ (بل) ملائم) المعنى، و غرض الكلام.

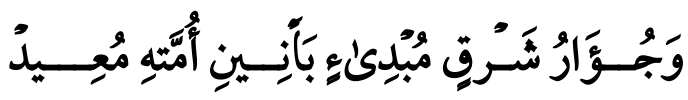

هذه الجملة معطوفة علئ ما قبلها بالواو( بل طحتته غمغمة العبيد) لاثـتراكها في فعل الطحن، وتقدير الكلام: بل طحنته غمغمة العبيد، وطحنه أيضا جؤار شرق، وفيها إيباز بحذف المسند: (طحنه) ربها لـيق المقام عن الإطالة في الكلام، لأن المقام هنا لإيجاز العوامل التي جعلت نغمه لا يؤثر فيهم، وهذا مقام يفيض بمرارة نفس الشاعر، فهو يتهم نفسه بالعجز، و التقصير، ما جعله يختزل الكلام، فيحذف المسند. من ثم، فقد ألقى الشاعر بمسئولية ضعف تأثير نغمه فيهم على نفسه فقال:(ربضت به الأصفاد) ثم أضرب عنها بإلقائها على أمته، في صورتين مشتركتين في فعل الطحن صادرا من غمغمة العبيد مرة (بل طحته

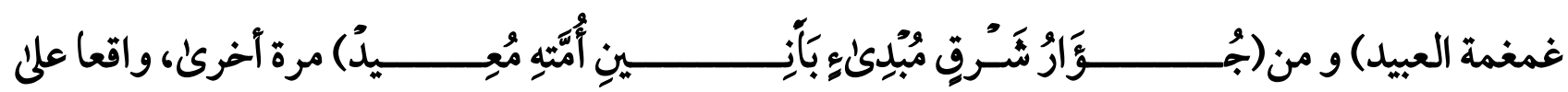
ضمير (نغم) المشبه به صوت الشاعر. 
وفي تعبيره بــــ (وجؤارشرق) بجاز عقلي علاقته المكانية، فيه يصف الأماكن بأوصاف ساكنيها مبالغة، فخيَّل آن البلاد بيا فيها من جبال، و زروع، و بيوت، وكل ذرة رمال، وحصني، تجآر بالاستغاثة من ثقل ما ينوء به كاهل العباد من ظلم المستعمر، وطغيانه، وفي صياغته بالطباق بين (مبدنء ومعيد) ما يرجح عظم البلاء، و خاصة أن البدء، والإعادة متعلقان بأنين أمته.

من ثم تبدو براعة الشاعر في تفصيل صورة المشبه به (نغم) وتتابع خيوطها با ييعلهاصورة نامية متدة، اعتمدت في تفصيلها على كنايات بنيت علن المجاز، ما جعل صورة المشبه به متشابكة، تعود علن المشبه (صوت

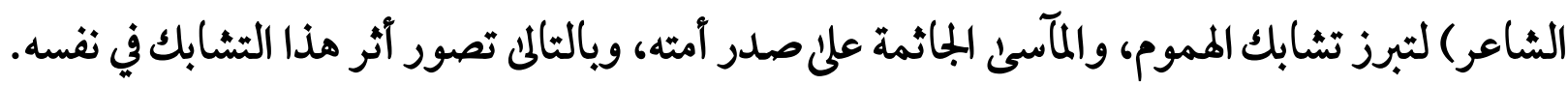
لذا كانت حيرة الـشاعر المتولدة من أ سلوب الا ستفهام المحذوف الأداة في البيت التألى، و كأن حذف الأداة جاء مصورا ضيق نفسه من جثوم هذا الواقع الكئيب علئصدره، وصدر أمته، فقال متحيرا:

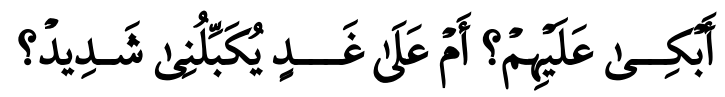

وقدجاءت صياغة الكلام في الأسلوب الخبرئ في صورة شبه كال الاتصال، إجابة عن سؤال مقدر، قد تولد من الاستفهام الحائر، فحواه: لمهذه الحيرة؟ وما السـبب في وصـولنا إلى تلك الحال الذليلة؟ فيجيب قائلا:

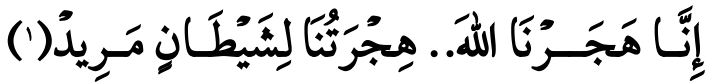

وفي الأسـلوب ريط رائع بين (إنا هجرنا الله) و الاستفهام المتعجب من هالفم الذليلة في مطلع المقطع

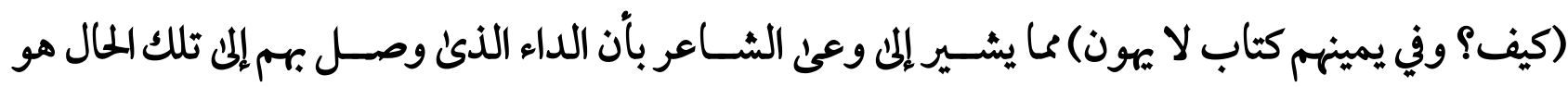
انصرسافهم عن القرآن الكريم حين جعلوه(في يمينهم) كناية عن التمسـك به ظاهريا دون تطبيق تعاليمه، ولو

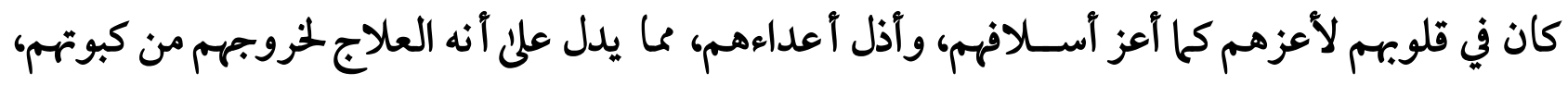
وإملاك أعداءهم. كما جاء الأسلوب في قوله: (هجرتنا لشيطان مريد) في صورة شبه كمال الاتصال إجابة عن سؤال مقدر

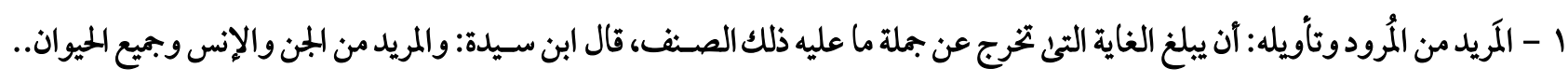

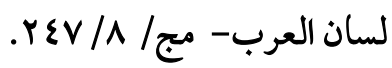


أيضا فحواه: إذا كنا قد هجرنا الله كما قلت، فإلى من كانت هجرتنا؟؟ فتأتى الإجابة: (هجرتنا لشيطان مريد) وهذا ما يولد العجب، والتعجب، فالأ سلوب الخبرئ هنا يفيض بهذا، كما يفيض بالسخرية، فعلى الرغم من

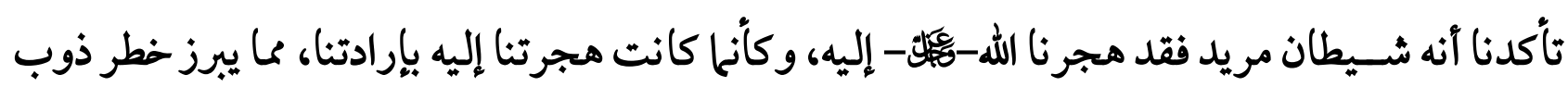
الشعوب الإسلامية في آشتات متفرقة من ثقافة غيرهم، بدعوئ التجديد، وإلباس ذلك ثوب الإسلام. وقد عدى الفعل بــــ (اللام) دون (إلى) فقال: (هجرتنا لشيطان) وليس إلى شيطان للدلالة على لهفتنا، واندفاعنا إلى الملاك، والشرور، دون روية، وهذا مناط العجب، لأن معانى الاستفهام تسرى في ثنايا آساليب المقطع كله، فنستشف منها التعجب، والتحسر، واستنهاض الممم، وإلماب المشاعر. وقد ا ستعار( شيطان مريد) للمحتل، أو لكل مستشرق يجمل المفا سد، والقبائح، مشوها الإسلام، والمسلمين، ولا يخفي أن الاستشراق، والتغريب، يفعلان الأعاجيب في تشويه الإسلام في نفوس أبنائه منذ

زمن بعيد(')

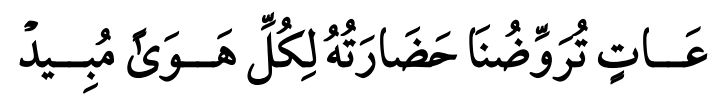

ثم و صف الشيطان بصفة أخرى (عاتِ) في ذسق تتابع الصفات بلا عاطف، و (ترو ضنا هضارته) استعارة تبعية في الفعل، شبه فيها استحاتة المستعمر - بالاستشراق تارة، وبالتغريب أخرىأ- في تشويه تراثنا، وثقافتنا، ولغتنا، وه ضارتنا بعملية ترويض السباع، وا شتق منه الفعل المضارع (تروض) لمذه العملية على

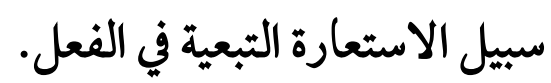
واختار فعل الترويض - با يدل عليه من صبر شديد، ومجاهدة طويلة، واختراع آلاعيب لفظية، وخداع

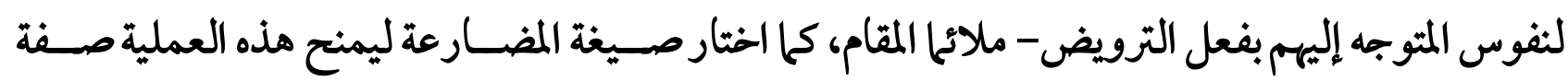
الاستمرارية، و المقصود الأهم من هذه العملية الشاقة المستمرة هو تشويه الإسلام في نفوس أهله، وتجميل كل هوئ مهلك(تروضنا حضارته لكل هوئ مبيد) ما يجعل الاستعارة هنا مفعمة بالسخرية من لا يفطن إلى هذا الواقع المرير، وبالتحسر علئ حال المسلمين، الذين ا ستكانوالحبتث مقصد المستعمر، وأذنابه من قديم التاريخ، و هذه صورة من صور ترويض المسلمين. 


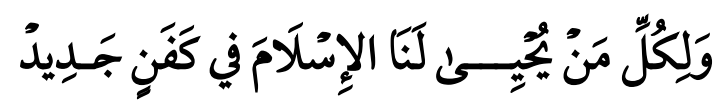

أما الصورة الأخرىن: من يقدم التراث الإسلامئ لأهله في صورة شائهة، تصوره سبب تخلفهم، بدعوئ

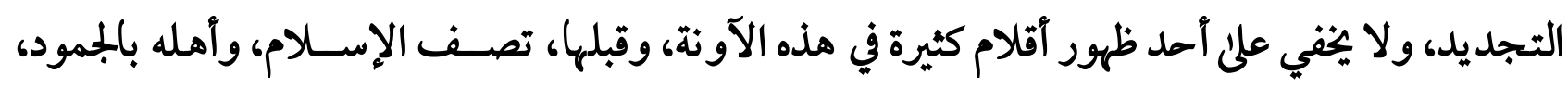
والتخلف.(')

من ثم يصوغ شاعرنا استعارة تبعية ثانية في الفعل (يحيح) يستعير فيها الإحياء لدعاوئ تجديد الإسلام، ثم اشتق منه الفعل (يجيح) لــــيديد) استعارة تبعية في الفعل، وهذه الاستعارة ترتبط بالأولى ارتباطا وثيقا،

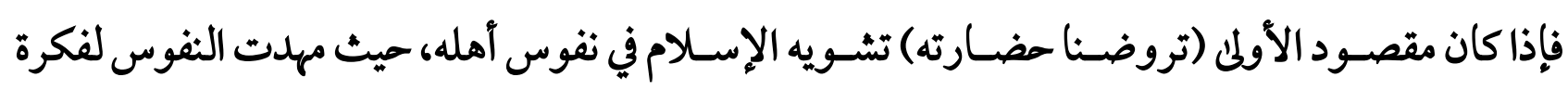

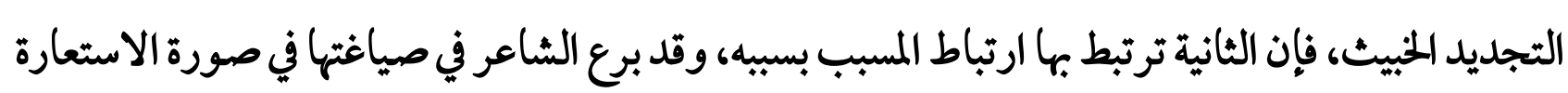
العنادية التهمية، وهمئ التي يتضاد طرفاها، ليبرز مرارة، وحسرة، وألما، وسخرية من هذا الواقع الكئيب. و الاسـتعارة هنا لم تصــور الإسـلام بالمريض مثلا، أو العجوز المرم، أو الثــــ القديم البالثي، فهذه

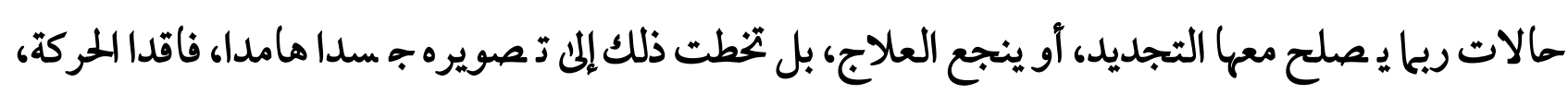

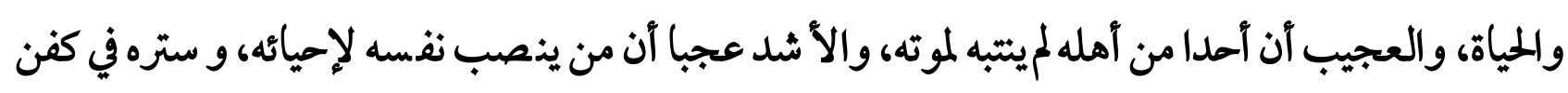

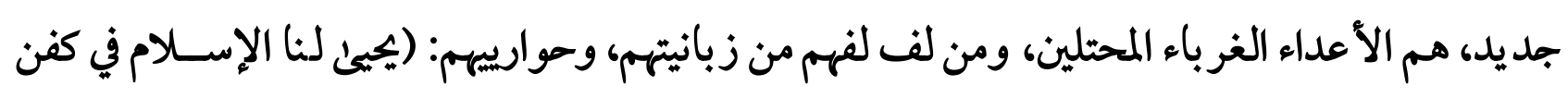
جديد)

ثم يستطرد شاعرنا متتبعا عناصر هذه الصورة الشاجية الساخرة، المتحسرة، فيستعير الكفن الجديداستعارة تصريحية- لهذا الغلاف المبهر الذئ يظهرون فيه الإسلام مع إفراغه من مضامينه، والا ستعارة ترينا

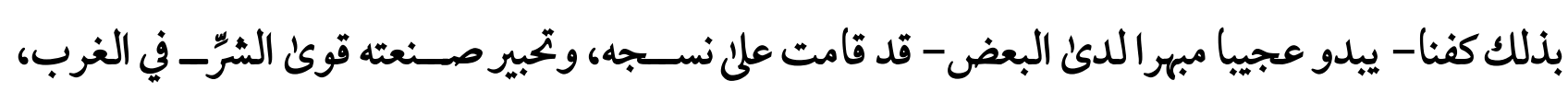

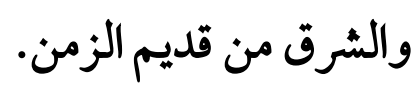

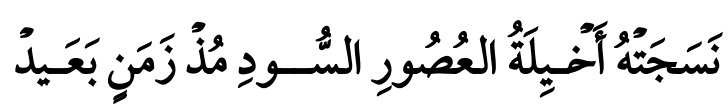

فقد أسند الشاعر نسج هذا الكفن الجديد إلى أخيلة غريبة، لكونها للعصور السود، و المراد بها العصور

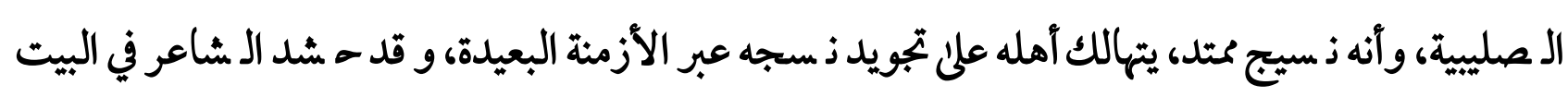


صورا متراكة، لكنها بارعة في نسجها، تمنح مو سيقى البيت ننخا شاجيا يلائم المقام، والسياق، و في وصف

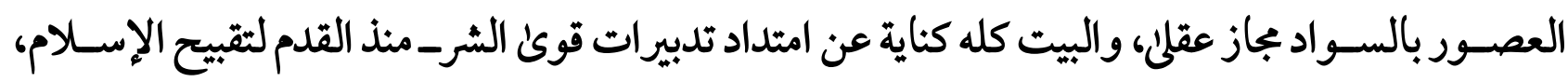

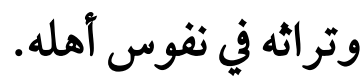

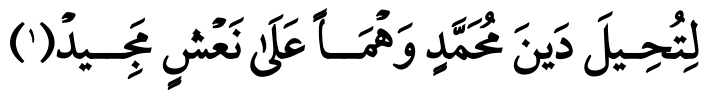

و هذه الصـورة تكثـف هدف المستعمر من خلال دعاوئ التجديد المزعوم، و هو إحالة دين محمد-

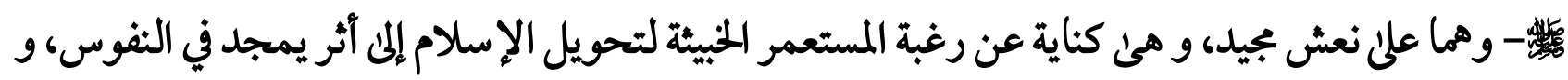

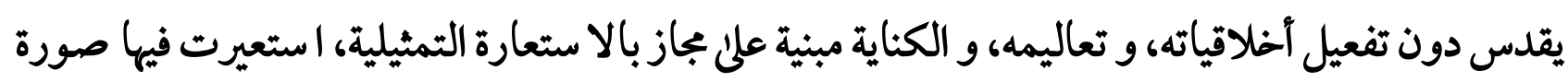
تحويل الدين إلمى وهم على نعش مجيد لصورة دعاوئ التجديد الذئ يحيله إلى صورة رائقة، لا تحوئ مضمونا. و الصورة ترتبط بيا قبلها، و با بعدها ارتباطا وثيقا، فلما صوره يجيخل لنا الإسلام في كفن جديد، كان

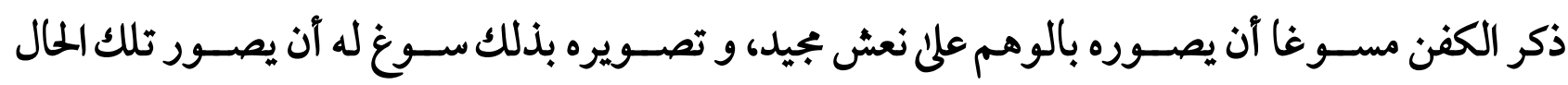

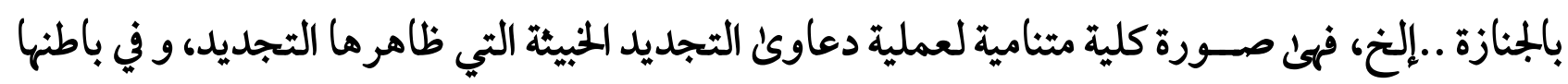

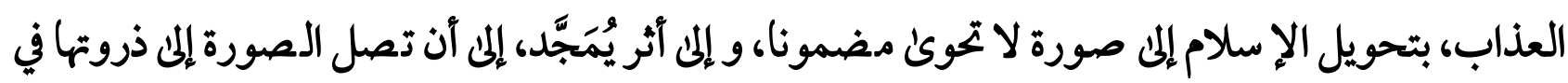

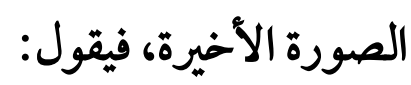

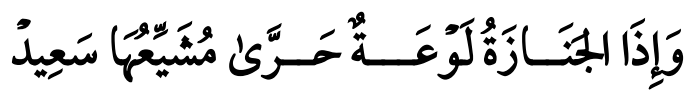

وهذه استعارة تمثلية أخرى تتم الصورة الكلية للحال التي صورتها الا ستعارة السابقة، فإذا وصل

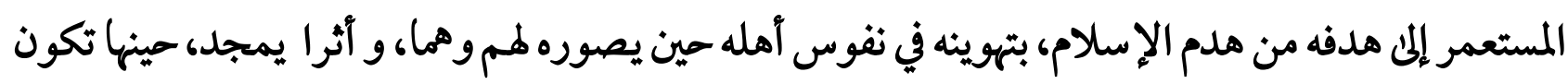

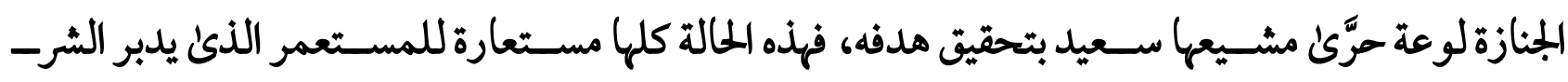

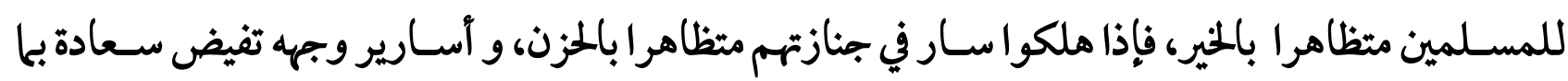

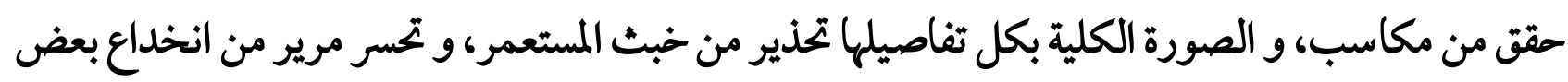

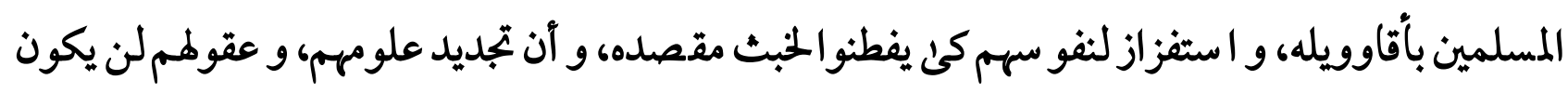
إلا من أنفسهم، لا من خلال مستعمر بغيض.

1- المجيد: فعيل للمبالغة، قيل:هو الكريم المفضال،وفيل: فعيل أبلغ من فاعل اللسان- مج/ / ؟ •r. 


\section{$\circ$.

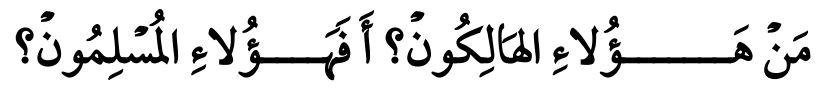

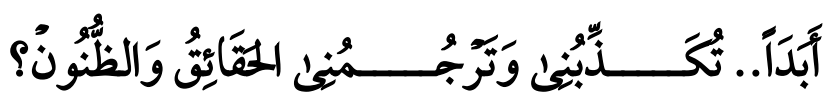

وفي خاتمة المقطع جاء المسـتفهم عنه (الملكون) ملاكم) المقام، وغرض الكلام، لوقوفهم مكتوفي الأيدئ أمام مؤامرة تشويه الإ سلام بدعوئ التجديد، وإذ بالتجديد المزعوم يكون موتا، وكفنا جديدا، وإحالة لدين محمد-

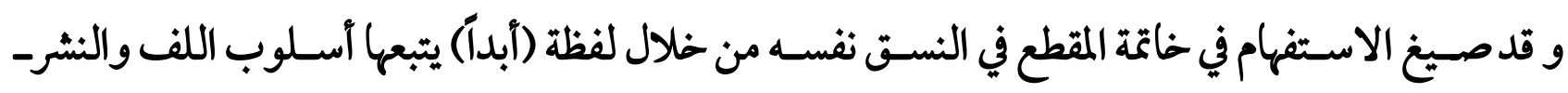

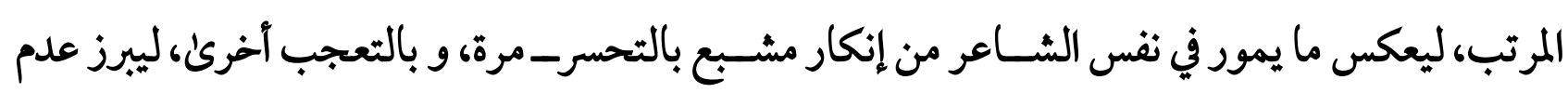
تصديقه أن صورة المالكين هذه هي صورة المسلمين، و نفيه أن تكون. 


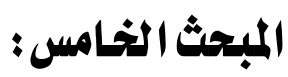

بين الدعوة إلى محارية الفساد، والعمل المثمـر

و المبحث يعالج وجوه البلاغة في المقطع الرابع، و يلاحظ على مفتحه ذلك الربط المحكم بينه و خاتمة المقطع السابق، في صياغة استهلت بأ سلوب المجر(من كان للإِ سلام) الذئ لا ينفك عن آ سلوب الإنشاء في صورة الأمر بعده (فليضرب بمعوله الفساد) ليبرز غايته من الإنكار الرافض في أ سلوبي الاستفهام في خاتمة المقطع السـابق، والذئ اسـتشـف التحسرـمن أولما (من هؤلاء المالكون؟) و التعجب المشــوب بالنفي من ثانيها (أفهوّ لاء المسلمون؟) ثم تدرج في الإنكار إلمان عدم تصديق نفسه، فيرفض واقعهم هذا رفضا قاطعا، يمتد آثره إلى المستقبل، مستشفا من تعبيره بلفظة (أبداً).

ومن خلال المفارقة بين صورة ماضيهم الماجد، و صورة المالكين تلك يثار تساؤل في أذهان المتلقين إذا

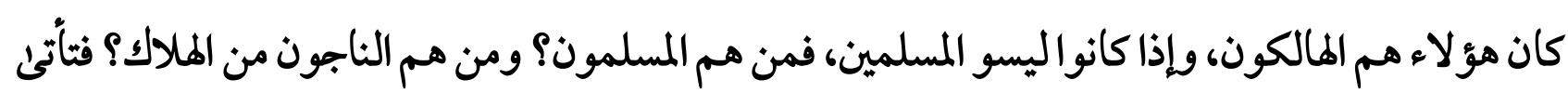
الإجابة في مستهل المقطع في شبه كهال الاتصال لتشفي غليل نفس المتلقى المتشوف لمعرفة من هم الجديرون بوصف المسلمين، فيقول:

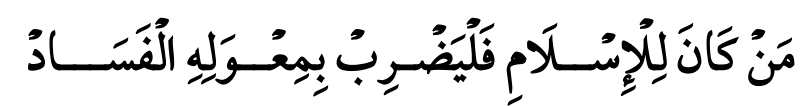

و هذه الغاية مع من حالهم كما وصـفت المقاطع الثلاثة من التخبط، والخنوع، والهلاك، قد لا يفيقون منها إلا بالأمر المباشر، الذئ يضع أيديهم على موطن الداء، وهو محاربة الفساد، في محاولة أخيرة من الشاعر لا ستفزازهم، وإلهاب مشأعرهم، وإذا كان الا ستفهام مفجراللمعانى، و صور البلاغة في المقاطع السابقة، فإن أسلوب الأمر هنا يؤازره في هذا الوصف، فهو مرتكز بيان المعانى، بحيث سرت أنفاسه في المقطع جميعه.

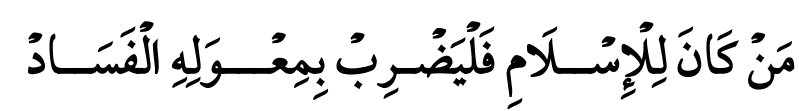

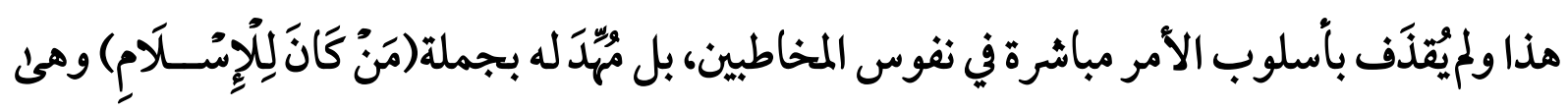
موصولة، وقعت موقع المبتدأ، محكمة البناء، فالموصول يحتاج إلى صلة تو ضح إبهامه، فإذا جاءت الصلة فقد 
أخرجت النفوس من ظلمة المجهول إلى نور المعلوم، و(مَنْ) اســم موصــول آشرب معنى الشرــط، لذا جاز اقترن خبر المبتدأ بالفاء، لأن جملة الخبر (فليضرب بمعوله الفساد) جاءت مسببة عن جملة المبتدأ، و "غالبا ما يتحقق هذا إذا كان المبتداً اســا موصـولاً بمعنى (ما أو من) الشر-طيتين في الإبهام والعموم، و كانت صـلته فعلا مستقبلا، أو ظرفا، أو حرف جر متعلقين بذلك الفعل "( ) وهذه الجملة مهدت لأ سلوب الأمر فأ شعرت بعظم المسؤولية التي يلقيها ال شاعر علئ عاتق من كان منتسبا للإِ سلام، أو بالأحرى' من أخلص حياته للإِ سلام، و الجملة جاءت مبهمة تستئير في النفوس سؤالا مؤداه: من كان للإ سلام ما ذا يفعل ؟ أو ما هئ المسؤوليات الملقاة على عاتقه؟ فتأتى الإجابة في الأمر بصيغة

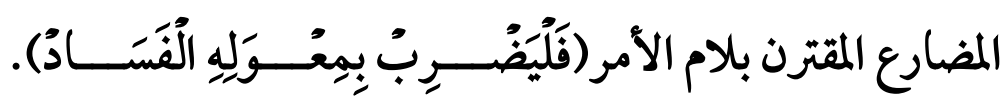
وعليه يكون أ سلوب الأمر مو ضحا إبهام الجملة المو صولة، فهنا إبهام في المو صول و ضحته الصصلة، وإبهام في جملة المو صول كلها و ضحه أ سلوب الأمر الخارج عن معناه- بمعونة السياق- للإلهاب والتهييج، مستفزا نفوس المسلمين للتوحد في وجه الفساد، لضربه في مقتل، وتهشيم آمّاّ رأسه. هذا، وقد أبدع شاعرنا حين صاغ أسلوب الأمر في صورة الاستعارة، التي يمكن توجيها على المكنية بتشبيه الفساد بالصخرة العظيمة، ثم حذف المشبه به، ورمز إليه بلازمه، وهو الضرب بالمعول، لكن الأنسب

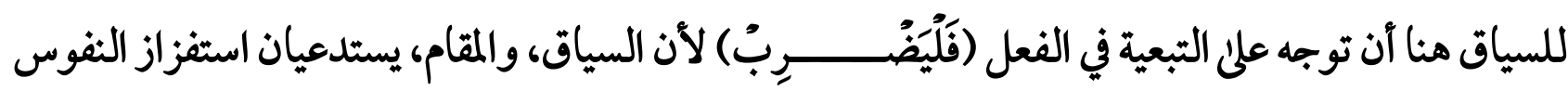
لماربة الفساد، والتشمير للعمل الماد.

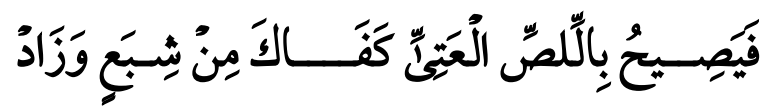

وإذا كان البيت السابق يصور حث الشاعر علائ محارية الفساد إبمالا، فهنا يفصل صور ذلك، مفتتحا بصـورة محاربة سر قة خيرات الشـعوب وآقواتها، في جملة (فيصـيح باللص العتى) معطو فة بالفاء على جملة(فليضرب بمعوله الفساد) في البيت السابق، مما يشعر بأن صياحه باللص العتى هو نفسه ضربه الفساد بمعوله، وبسرعة تصورها (الفاء) و اللص العتى مستعار للمستعمر استعارة تصريجية تفيد أنه تجاوز الحد في 
سرقته آقوات الشعوب، و جملة (كفاك من شبع و زاد) كناية عن وصول المسروقين حد الضجر. و افتاح التفصيل بصورة- سرقة أقوات الشعوب، وخيراتها - معطوفة بالفاء على الصورة العامة يشعر بخطورتها، وأهميتها، من ثم قدمها على غيرها، و عطفها بالفاء دون الواو حثا على سرعة الثطبيق، لأنه الـ سبيل الوحيد لخروج المسلمين من كبوتهم، و هذه الصورة تتردد في شعر الشاعر.((')

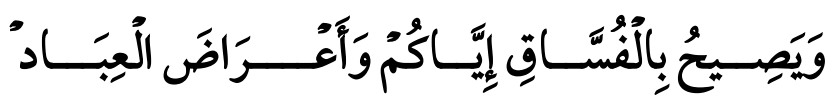

و يعدد الشاعر صور الفساد فيكرر الأمر، و بصيغة الفعل نفسها (و يصيح بالفساق) و الجمملة معطوفة على سابقتها (في صيح باللص العتى) بالواو لا شتراكها في الإنشائية، و ا شتراكها في الفعل (يصيح) و جملة (إياكم و أعراض العباد) تحذير صريح يتوجه به ال شاعر إلى المخاطبين، يـ ستفز نفو سهم، آمر المم آن يخذروا الفساق مما يشيع الفوضى في المجتمع و يفكك أمنه بأن لا يتركوهم يششيعون السوء منتهكين أعراض العباد، دون رادع من دين، أو خلق، أو خوف من حساب.

و قد كرر المســند (يصـيح) ثلاث مرات في هذا السـياق فكان إلماباً، واسـتئارة لنفوس المخاطبين، و مشاعرهم المفعمة بالألها و الشجىل لواقع المسلمين المتفرق الخانع، الصاغر أمام ظلم، و فسق المستعمر كما تجلى في المقاطع السابقة، فهو دعوة تستفز النفوس إلى التوحد، و محارية الفساد، لأنها السبيل الوحيد للوقوف في وجه الطاغية "فقد يكون تكرار ذكر المسـند لإثارة حماسـة المخاطبين في مواطن الترويج للأفكار، و مقام الترغيب فيها، و لإرادة استارة كوامن المشاعر في نفوس المخاطبين، و يحسن تكراره لغرض زيادة الإيضاح، و التقرير، في مقام إثارة المحاسـة، و سـائر العواطف، و للرغبة في ترسـيخ ما يدل عليه اللفظ المكرر في

النفوس" (r) (2) (2)

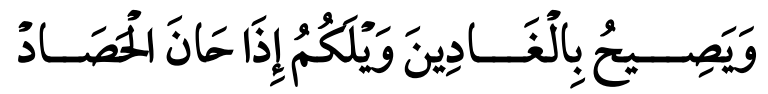

1 - يرابع:صـورة المحتل فن الشعر المصرئ - بحث - د/ عبد الكريم أمد مغاورئ-صــــــ ع ع- بجلة جامعة المدينة العالمية - العدد

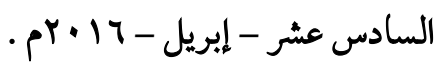

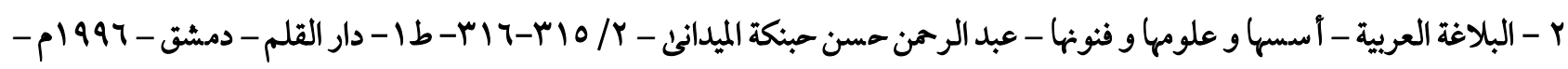


ثم يصف الشاعر كدح الفلاحين حين المحاد، و المستعمر متربص بهملينقض علن ثمرة عرقهم، في

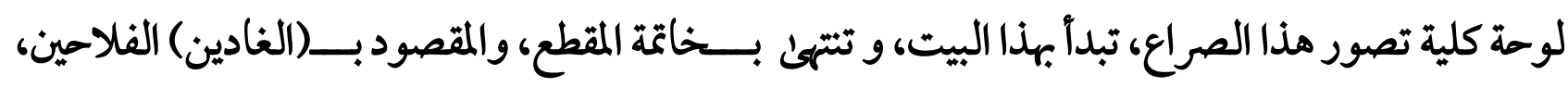

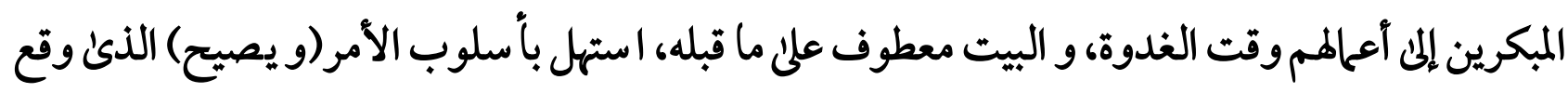

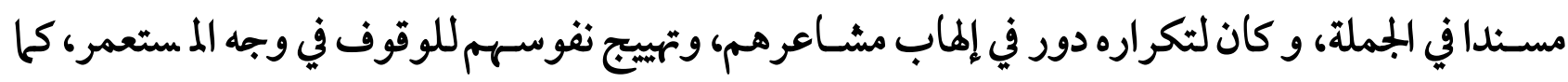

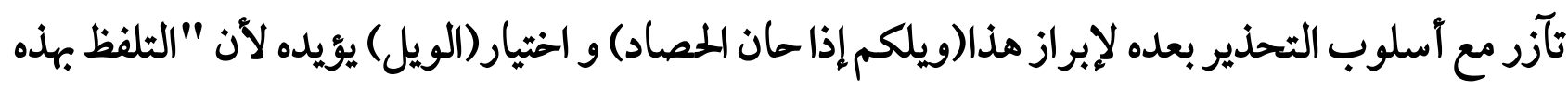
الكلمة يكون إعلانا با صطلاء عاقبة مهلكة لعمل، أو تصرف: وعيدا، أو ندبة، و ا ستغاثة، أو تحذيرا، أو ما

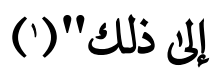

و التحذير بهذه اللفظة يممل بين مطاويه إشفاق الشاعر عليهم من المستعمر المتربص بهملينهب ثمرة عرقهم وقت الحصاد، كما يحمل استفزازا لنفوسهم أن يجالدوه لتكون ثمرة كدههم لهمم وحدهم، و في باطنه دعوة إلى العمل المثمر الجاد، و ترك الكسل و التواكل.

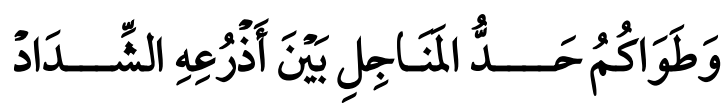

من ثم يعمق الشـاعر من صسـورة موعد الحصـاد، و معاناة الفلاحين بين كدههم، و بين ذئب متربص لنهب ثمرة كدمهم، فيعطف عليها و صف حالفم في هذا الوقت بالا ستعارة التبعية في الفعل (طواكم) معبرا

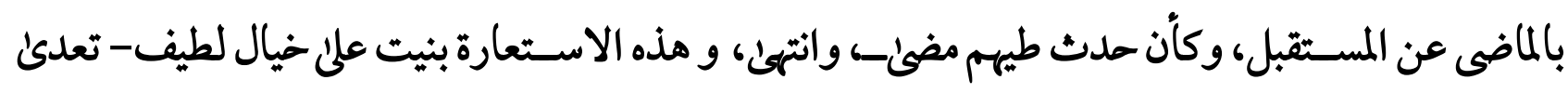

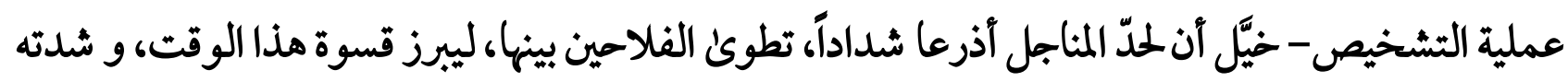

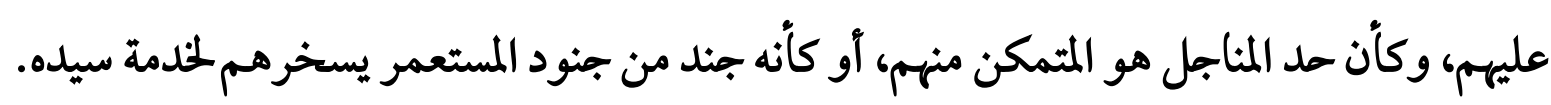
و الصـورة تبدو عليها الجدة، و الاختراع، لبنائها علن عكس الواقع، فبدلا من تحكم الفلاحين في حد

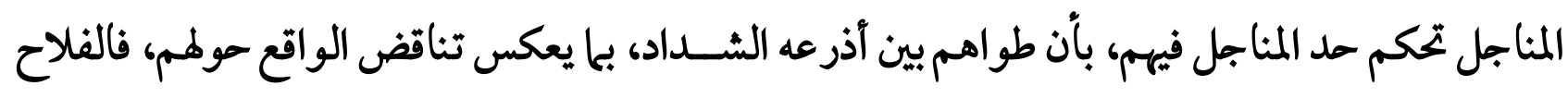

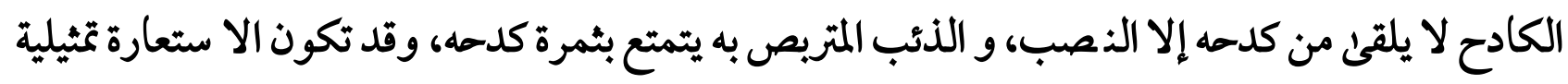

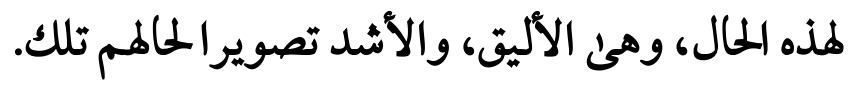

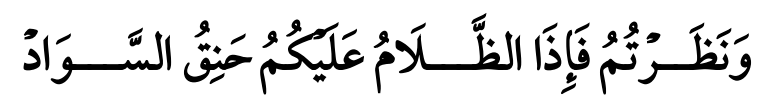

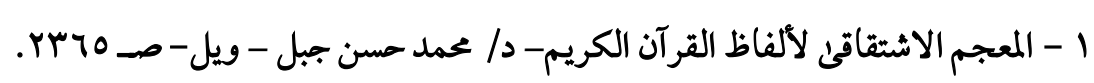


و إذا كان شاعرنا قدوصف نفسية الفلاحين في البيت السابق كان من الوفاءلعناصر اللوحة الكلية أن يصور حال الذئب المتربص بهم حين شقائهم لينقض عليهم، فقال (ونظرتم فإذا الظلام) و التعبير بــ(إذاذا)و عطفها بالفاء يفيد خفة انقضـاض المستعمر عليهه، و سرعته " فهئ ظرف لما يستقبل من الزمان، تدل على فئل استحضار حدث، أو أمر غير موجود الآن، لكنه سيقع في المستقبل، فقيها معنى الانقطاع، لأن عدم المدوث

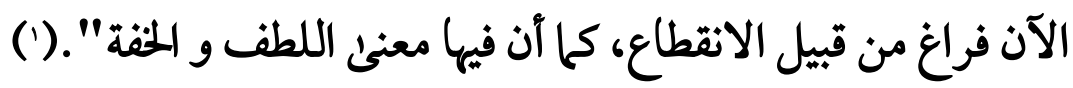
هذا، و قد ا ستعار الظلام للمستعمر، و جعله حنق السواد عليهم، على سبيل الا ستعارة المكنية، التي شخصت الظلامه، بعد حذف المشبه به، الرمز إليه بلازمه، صفة الحنق، لكنه لميضفها إلى الظلام المشبه في الأصل، علي، ما هو معروف في المكنية- بل أضافها إلى صفة السواد، و هئ أخص صفات الظلام، و

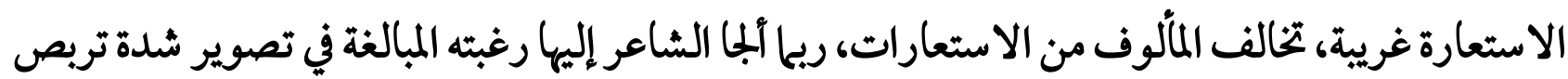
المستعمر بهم، فهو يتظر لحظة الحصاد بفارغ الصبر، و ريجا كان تصوير الفلاحين كالفريسة، و هو يتربص بها،

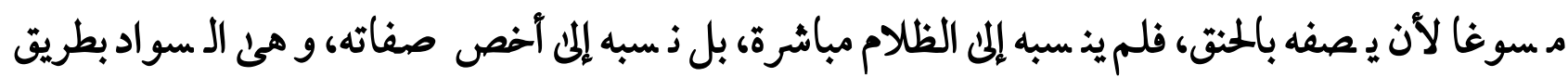
الكناية عن نسبة، و بهذا تكون الكناية داخلة في تشكيل الاستعارة، و عنصرا من عناصر بنائها. (')

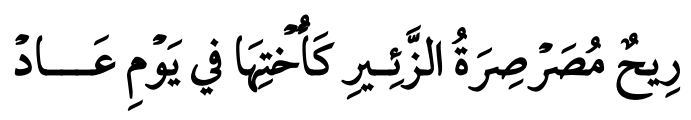

و يتابع الشاعر وصف مذا الظلام في إطناب يستدعيه المقام، فيفرع على الا ستعارة السابقة (الظلام عليكم حمق السـواد) اسـتعارة أخرى تكون فــورة ثانية لمبالغة الثـاعر في تحذيرهم، و الإشـفاق عليهم،

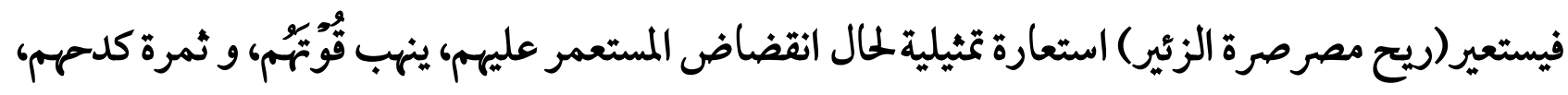

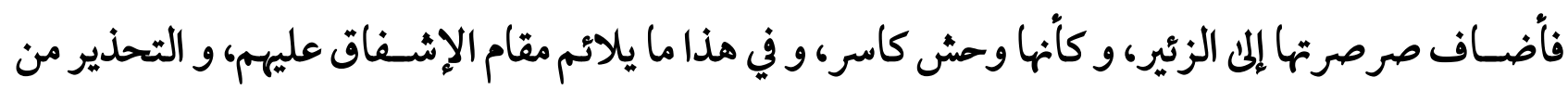

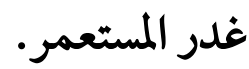
و جاء وصـفها باســم الفاعل (مصر-صرة) ملائم) شـدة الحال، فمعنى (صرّّ-صرصر) يدور حول: "تضامّ، و التئام، و تداخل شديد يمنع الانتشار، و منه: صرصرت الشئء: جمعته، و رددت أطراف ما انتشر مركر

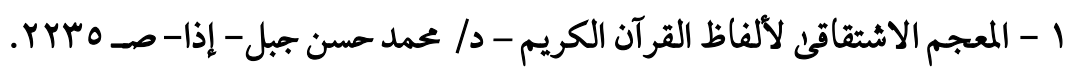

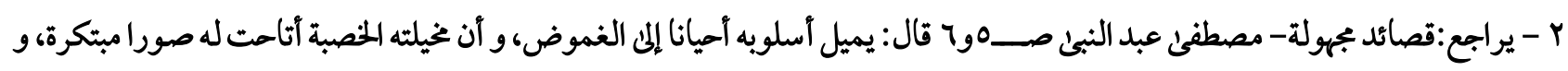
تصاوير بجنحة يكثر تداخلها، و توالد بعضها من بعض تصن. 
منه."()

ثم شــبه تلك الريح بريح يوم عاد( بأختها في يوم عاد) معبراً عنها بأختها ليبرز أنها لا تقل عنها تدميراً، فيذ سحب بدوره علئ المشـبه، عاك ساً آثار هذا التدمير، و أثر تدمير ريح قوم عاد معلوم، قدصـورته الآيات

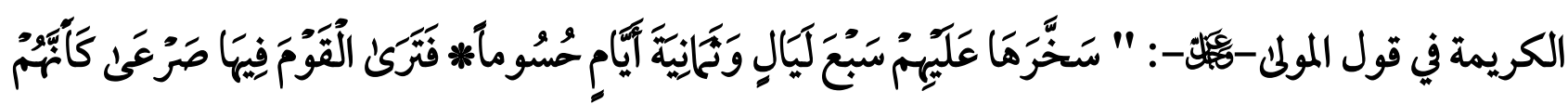
أَعْجَازُ نَخْلِ خَاوِيَّة*" (لحاقة: V) " ولمِينص في التشبيه على وجه الشبه لتعدد الصفات المحتملة، و المرتبطة بجذوع النخل الخاوية، لتنسحب على الصرعئ من قوم عاد، كالحفة، و الحقارة، والتكور، و الا ستدارة، مع دفع الريح حتى تلتقى الأرجل مع الرؤوس، و يحتمل مع هذا انتزاع الحياة، الذئ تحقق في الطرفين"().

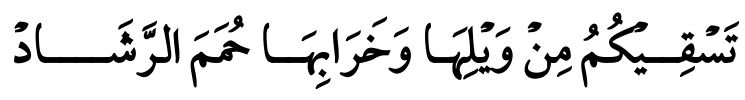

و قد تخطى الشـاعر تشـخيص الريح، فجعل لها فعلا قاسـيا باسـتعارة الفعل (تسـقيكم) التي كانت

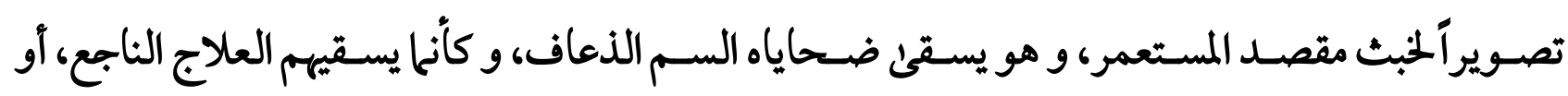
الشراب اللذيد، فهى تسقيهم حم الرشاد، و في إضافة حمم إلى الرشاد ما يشير إلى هذا التناقض، ثم إن مصدر السقيا من آبار ويلِ، و خرابٍ تلك الريح المدمرة، ما يتواءم و تحذير الشاعر من خبث مقصد المستعمر، الذئ سرى في حنايا اللوحة الكلية للفلاحين، الذين يشـفق عليهم الشـاعر من أولما(و يصـيح بالغادين.. حمم الرشاد) إلى آخرها.

كما آن شيوع ألفاظ (الويل الحنق السوادو الريح مصرصرة الزئي والحمم) في اللوحة "تحمل في طياتها قيها ودلالات سـلبية كالعار والذل واللززئ والمزيمة، وتكرار حرف الصــاد يدل على توتر نفس الشــاعر، ورغبته العارمة في استبدال الواقع الجاثم علن صدره، وتخطيه إلى واقع جديد"(") و أخيرا فإن ا ستعارة الظلام للمستعمر - و جعله حنق السو اد علئ المسلمين - في نهاية المقطع الرابع و الأخير في القصيدة، يتلاقى و استعارة الليل له- و جعله ينفض فوق المسلمين من يأسه قلق النجوم- في بداية

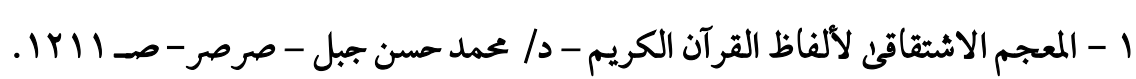

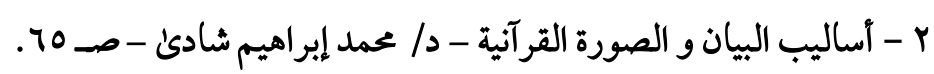

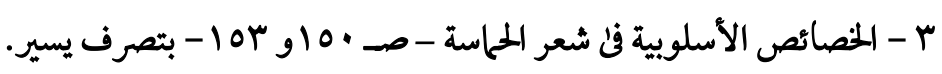


المقطع الأول، هذا التلاقلى يحكم ترابط القصيدة معنويا، فترد به خاتمتها على مطلعها، كما يشير إلى المفارقة بين

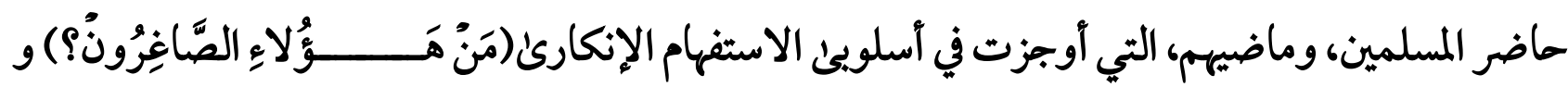

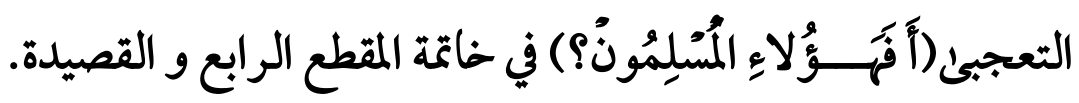

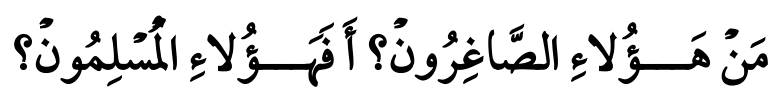

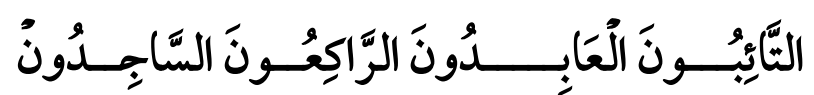

و جاء المستفهم عنه في خاتمة المقطع (الصاغرون؟) ملائم) مضمونه الذئ ينعلى على المسلمين صغارهم أمام من ينهب ثمرة عرقهم، في مفارقة ساخرة، تولدت من ثباتهم علئ تلك الحال الصاغرة، و ثباتهم في الوقت ذاته على التوبة، والعبادة، والركوع، والسجود، مما جعله لا يصدق أن من ثبتوا على هذه الصفات هم آنفسهم الذين يراهم قد ثبتوا على الصغار، والموان.

وفي هذا سمن تخلص يرد خاتمة القصيدة علئ مطلعها، فثباتهم على هذه الصفات لا يجتمع و التعجب

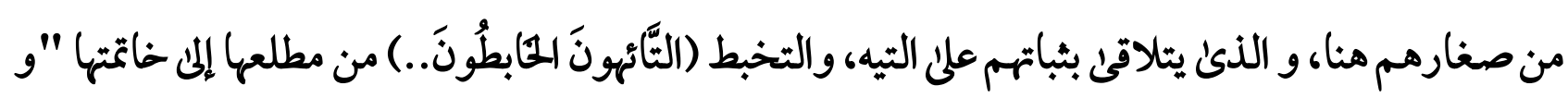
حسن الخاتمة كحسن التخلص من غرض إلى غرض، وثيق الاعتلاق ببناء القصيدة.. لأن حسن الختام آتيه من

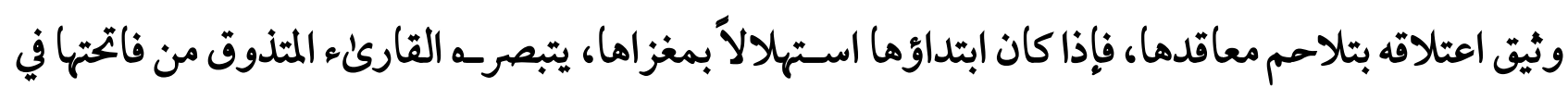
تجمع معانيها بأقسامها، وما بينها لتبين عن مغزاها بوجوه مختلفة من الإبانة، ففي الا ستهلال إلاحة، وإ شارة.

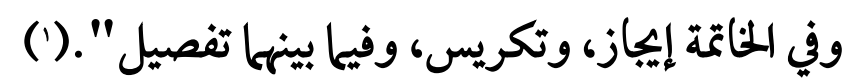




\section{الخاتقة}

وظفت أساليب البلاغة للتعبير عن فكرة القصيدة، و تشكيل صورها، و معانيها الجزئية، ملائمة أسى نفس الشاعر، وتحسره لهوان أمته، في مفارقة بين ما ضيها، و حاضرها، و قد خلصت الدرا سة إلى نتائج، من أهمها:

ا - وظف أ سلوب الا ستفهام في مطلع الق صيدة، و خاتمها، فكان له أثره في توليد أ ساليب البلاغة، وصور البيان في القصيدة كلها، حيث كان أداة إحكام لصنعتها، و دقة أدائها، وحسن سبكها، تواءمت مع خيط نفسنى، و شعورئ، و معنوئ سرىل فيها، من المطلع إلى الخاتمة، كحا كان أداة ربط بين المقاطع، يوجز مضمون السـابق، و يعد تمهيدا للتالى، بالإنكار تارة، و التعجب أخرىن، وهذه طريقة في بناء الشـعر تعرف في البيت المفرد بـ (رد العجز على الصدر) و في المقطع، أو القصيدة بـ (رد الخاتمة على المطلع) وهو لون بديعىل له أثره في إحكام صنعة الشعر. r- اعتمد الشاعر في تصوير معانى القصيدة على الاستعارة (تصريجية، و مكنية، وتبعية) فجاء كل منها ملانحم الموقف، والسـياق، وغرض الكلام، فأحيانا تأتى المكنية وقد اسـتدعاها المقام وغرض الكلام، و في أغلب الأحوال يكون الغرض إبراز دور الفعل في تصــوير المعنى، فيتجاوزها إلى التبعية، و كثيرا ما اعتمد عليها الشاعر في تصوير المعانى، فكثف من التصوير بها، ملاحظا الترابط بين صور مها، كأنما يتو الد بعضها من بعض، أو يتسبب بعضها عن البعض، كما اعتمد في تصويره على الكناية، إلا أنها قد تأتىلى أحيانا و هئ مقصود الشاعر من التصوير، و غالبا ما تأتى مبنية على بجاز بالاستعارة. ب- وظف الشاعر أسلوب التشبيه أحيانا، وقد خلع عليه من نفسه، ويث فيه من روحهه ما جعله يفيض بالحياة، من خلال تفصيل صورة المشبه به، في استقصاء يتتبع جزئياتها، صورة تلو الأخرىن، و قد صيغت في صور الكناية المبنية على بجاز، مشكلة مع غيرها صورة المشبه به، لتعود بدورها على المشبه، مبرزة المعنى الذئ وظف أسلوب التشبيه لتصويره. ع - جدد الشاعر في شكل القصيدة، كما كانت له صور مبتكرة من أمثال (السوط يرفل حولها و الموت أنسره تحوم) وتشبيه صوته في قومه بنغم في سمعهم شريد، و وصفه بكونه:(ربضت به الأصفاد بل طحنته غمغمة العبيد) و قوله:(ريح مصرصرة الزئير) و قد يلجأ الشاعر إلى الإغراب في التصوير نادرا كقوله:(فإذا 
الظلام عليكم حنق السواد).

0- وظف الشاعر أسلوب شبه كمال الاتصال بالا ستئناف البيانى، جوابا عن سؤال مقدر، فاصطنع

حوارا داخليا، اسـتئار نفوس المتلقين للتجاوب معه وجدانيا، ونفسـيا (أنا منهم ) (إنا هجرنا الله ... هجرتنا

لشيطان مريد)

7- راوح الشاعر في توظيف أساليبه البلاغية بين الحبر، والإنشاء، الذئ جاء كل منها ملائما موقعه من

السياق، و مقامه الذئ وظف فيه.

V- وظف الشاعر أسلوب الاستطر اد- ببراعة فنية- فرأيناه يستطرد فيمنح الموصوف صفات متتابعة

دون عاطف، حرصا منه على استقصاء جوانبه، فيترك العطف بينها وكأن هذه الصفات المتتابعة صفة واحدة، شكلت فيل بينها صفة للموصوف، متأثرا في هذا النسق بالقرآن الكريم.

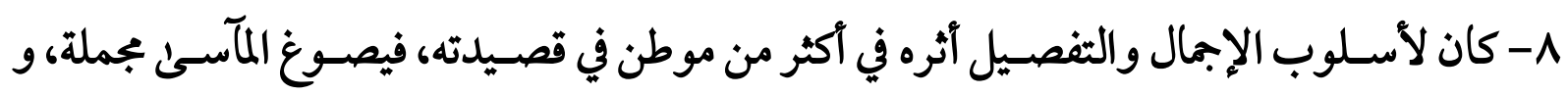
يحسن التخلص إلى تفصيل جزئياتها، دون إشعارك بفجوة في الانتقال من الإجمال إلى التفصيل، فيها يعرف بـ (حسـن التخلص) وهو من أدوات الربط التي تبرز إحكام صـياغة القصـيدة، ودقة نسـهها، و الانتقال من

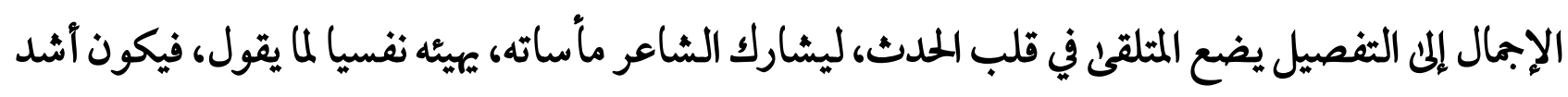
استجابة لتمثله.

ه- لعبت المقابلة بين الصور دورا بارزافي تصوير شدة واقع المسلمين مصورة قسوة الحدث حالى النوم والصحو، وأن نومهم لا يقل فزعا، ورعبا وهوانا عن صحوهم، فهم لا يذوقون النوم إلا إغفاءات، تزيدهم فزعا على فزعهم. و أخيرا فهذه طاقة النفس في دراسـة و تحليل وجوه البلاغة في هذه القصـيدة، فإن كان هناك من نقص فتلك هئ طبيعة البشر، و أرجو - من باب الذصيحة للعلم- من أ ساتذتى الأجلاء، و من كل قارئء- وُهِبَ

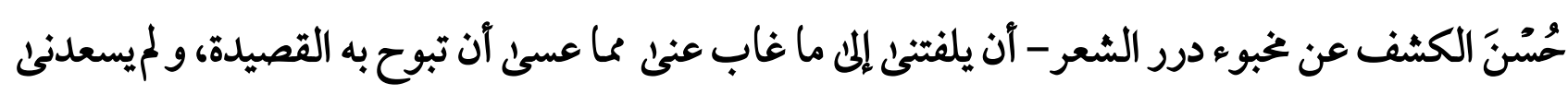
الحظ بالكشف عنه، فالكمال الله-كئلئ- وحده.

\section{و الحمد لله آولاًَ و آخراً}

د: عبد العزيز أبو العزم عبد المقصود سليم 


\section{فهرس المراجع}

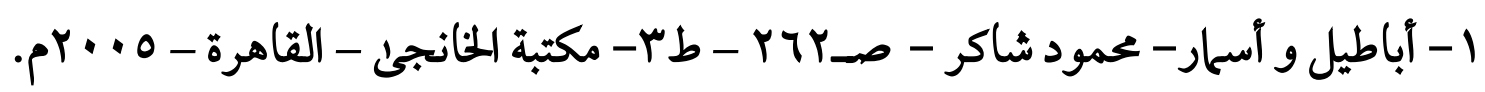

ץ- أسـاليب البيان و الصــورة القرآنية - د/ محمد إبراهيم عبد العزيز شـادئ-دار والمى بالمنصـورة- طا .01990

r- أسرار البلاغة- عبد القاهر الجرجانئ - ت- محمود شاكر -ط ا - مطبعة المدنى بالقاهرة 991 ام. ع - (آل) في الكلام العربى - حمدئ الجبالىه - بجلة جامعة الأزهر بغزة - المجلد الســابع - العدد الأول $p+\varepsilon$

ه - أنسنة الليل في شعر ذى الرّمّة-عبد الكريم يعقوب و ديها يونس - بجلة دراسات في الغة العربية و آدابها-

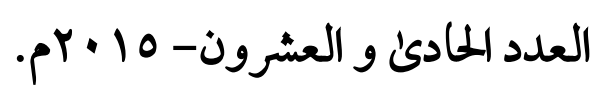

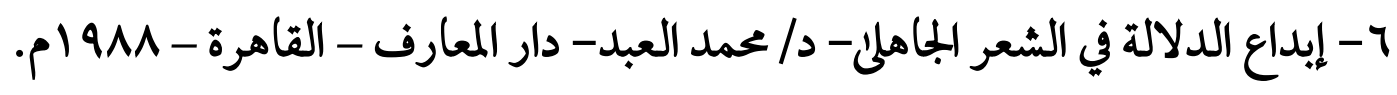
V- اقتران خبر المبتدأ بالفاء- د/ حصة بنت زيد بن مبارك الر شود - مجلة معهد الإمام الشاطبئ للدرا سات

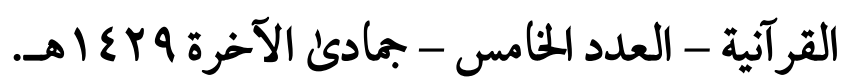

1- الأدب الأندلسئ - مو ضوعاته وفنونه- د / مصطفي الشكعة- طع - دار العلم للملايين - بيروت p $19 \vee 9$ 9 - الأصوات اللغوية - د / إبراهيم أنيس - ط 7- مكتبة الأنجلو المصرية - عه9 ام. • 1 - الإيضـاح - الخطيب القزوينى -ت-د/ محمد عبد المنعم خفاجى - طب- دار الجيل - بيروت-لبنانp 1994 1 - البلاغة العربية - أ سسها و علومها و فنونها - عبد الرحمن حسن حبنكة الميدانى - طا - دار القلم -

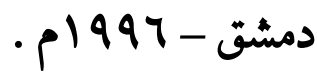


r ا - البلاغة فنونها وأفنانها - علم المعانئ - د/ فضـل حسـن عباس -طع - دار الفرقان للنشر-و الثوزيع $.0199 v$

$$
\begin{aligned}
& \text { ץ1 - التصوير البيانئ - د/ عحمد أبو موسى-طع -مكتبة وهبة- } 991 \text { ام. } \\
& \text { ع ا - التصوير البيانئ - طبيعة الدلالة وفنيات الأداء- للباحث- } 10 \text { • rم. }
\end{aligned}
$$

10 - التصوير الفنى في شعر محمود حسن إسماعيل - د/ مصطفي السعدنى - منثأة المعارف بالاسكندريةبدون تاريخ.

17 - الحرب العربية الصـهيونية- حرب 1 19 ام- موفق عبد الله الثـهابئ - بحث دبلوم الدراســات الفلسطينية-17 +rام.

IV - اللا صائص الأ سلويبة في شعر المحا سة بين أبئ تمام و البحترئ-أحمد صالح محمد النهمئ- جامعة أم

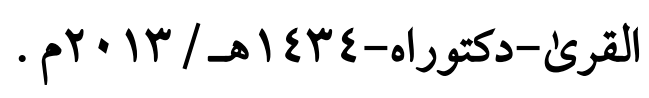
11 - الديوان-العقادو المازنئ - ط ع - دار الشعب - بدون تاريخ. 9 19 - الثـعر المعاصر على ضــوء النقد المديث- مصـطفي عبد اللطيف السـحرتى- طץ- تهامة للنشر-و

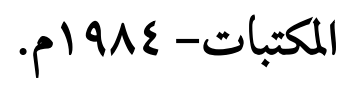

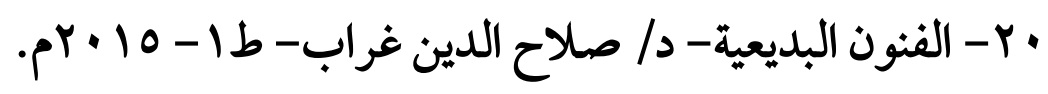

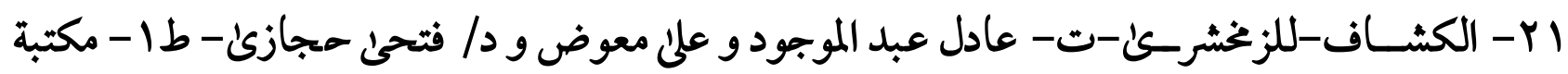

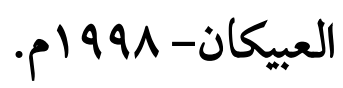
r r- المثل السائر - ابن الأثير-ت- د/ أمد الموفي و د/ بدوئ طبانة- طץ- دار نهضة مصر - بدون تاريخ.

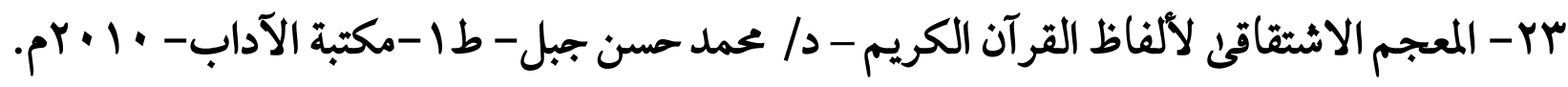
ع ץ- الموازنة بين شعر أبي تمام والبحترئ - ت- السيد أمدصقر ط ع- دار المعارف. Po - بغية الإيضاح- عبد المتعال الصعيدئ- مكتبة الآداب-999 ام. 
جr - بلاغة التراكيب-دراسة في علم المعانى -د/ توفيق الفيل -مكتبة الآداب-بدون

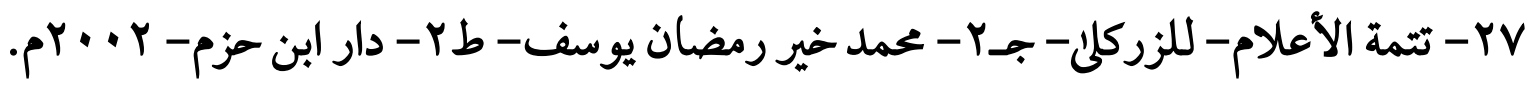

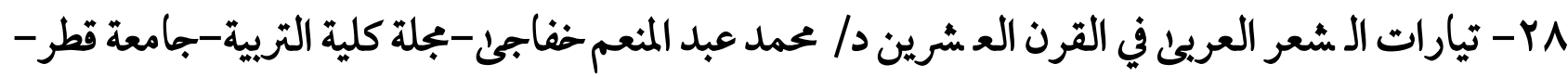

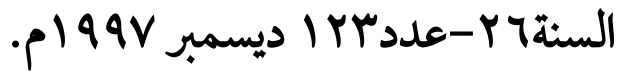

9 - خصائص التراكيب- د/ محمد أبو موسى - طع - 7 | ع (هـ - 997 ام - مكتبة وهبة - القاهرة. • ب- دلائل الإعجاز - عبد القاهر الجرجانئ - ت- محمود شاكر - مطبعة المدنى بالقاهرة - 991 ام.

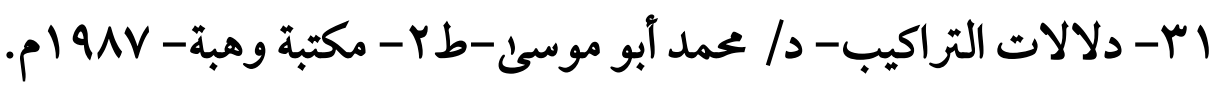
r r- ديو ان عابر سبيل للعقاد- مؤسسة هنداوئ للتعليم والثقافة-r I +rم.

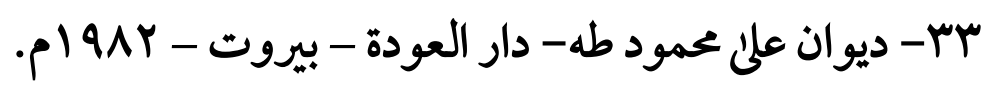
ع r- سيرة ابن هشام - جـ ع - سلسلة الذخائر ب ا Y - الميئة العامة لقصور الثقافة. هب- شرح ديوان الحماسة - المرزوقى - أحمد أمين و عبد السلام هارون-ط - - 97 ام. جr- صورة المحتل في الشعر المصرئ - بحث - د/ عبد الكريم آحمد مغاورئ- بجلة جامعة المدينة العالمية -

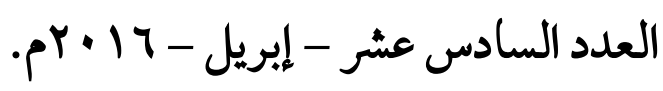

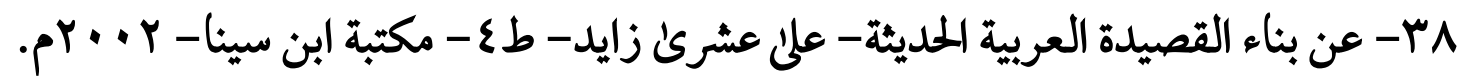
هץ- عيار الشعر-ابن طباطبا العلوئ- ط ا - دار الكتب العلمية - بيروت - ra19 ام. • ع- فن التشبيه - د/ على الجندى - ط ا - مكتبة نهضة مصر- 190 ام. | ع - قطرات الندئ- معالم الطريق إلى فقه الشعر - د/ محمود توفيق سعد- ط | - Y Y I اهـ . r ع - لسان العرب- ابن منظور- طبعة دار الحديث-القاهرة س + . م. rع - مراجعات في الآداب والفنون - محمود عباس العقاد-مؤسسة هنداوئ للتعليم و الثقافة- با + rم. 
ع - محمود حسن إسحاعيل - سلوان محمودوعزت سعد الدين- الميئة المصرية العامة للكتاب - القاهرة-

$\cdot r \cdot 0$

0 ـ - محمود سمن إ سماعيل - ق صائد بههولة- م صطفي يعقوب عبد النبل - النادئ الأدبى الثقافي بجدة -

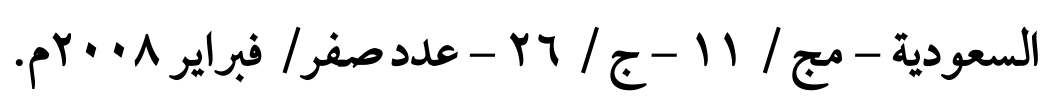

جع - بجلة الجامعة الإسلامية للعلوم الإنسانية- عدد الأول - المجلد العشرين - يناير ع ا بrم.

$$
\text { ع V - ججلة (المسلمون) العدد الأول- سبتمر - } 90 \text { ام. }
$$

^ع - معانى حروف الجر بين الوصف النحوئ القديم والاستعال المعاصر -مارينا نجار - ماجستير - الجامعة

$$
\text { الأمريكية- بيروت- }
$$

ه - - ملازمة النفي في اللغة العربية الفصيحة- طايل محمد آحمد الصرايرة- ماجستير- كلية الدراسات العليا

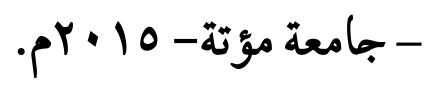

• - من أسرار حروف الجر في الذكر اللحكيم - د/ محمد الأمين الخضرىئط ا - مكتبة وهبة- 919 ام. ا - - منهاج البلغاء و سراج الأدباء-حازم القر طاجنى-ت- محمد الحبيب بن الخو جة- طب- دار الغرب

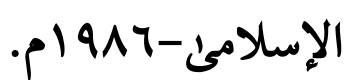

Y Y - نظر العقاد في طبيعة العمل الثـعرئ في العصر _ الحديث- مهدى عبد الحسـين- بجلة كلية التربيةالعراق-السنة الرابعة- عدد السابع-19A إم

بسم الله الرحم الرحيم 
هذا م ستخلص درا سة التحليل البلاغي لق صيدة (المسلمون) للاشاعر محمود مسن إ سهاعيل التي جاءت في مقدمة، و تههيد، و خمسـة مباحث، و خاتمة، المقدمة: أبرزت هدف الدراسـة، و دواعيها، و التمهيد: فكان إيبازاً لحياة الـ شاعر، و أثرها في شعره، و منا سبة القصيدة، المبحث الأول: البناء الفني للق صيدة في أربعة مقاطع، المبحث الثاني: عالج بلاغة المقطع الأول بعنوان: وصف حال المسلمين بين التخبط، و الضياع، المبحث الثالث: و يعالج بلاغة المقطع الثاني بعنوان: التعجب من حال المسلمين، و في يمينهم القرآن الكريم. المبحث الرابع: و يعالج بلاغة المقطع الثالث بعنوان: موقف الشاعر من حال أمته. المبحث الخامس: و يعالج بلاغة المقطع الرابع بعنوان: بين الدعوة إلى محاربة الفسـاد، و العمل المثمر ـ الخاتمة: و ضــــت أهم النتائج، منها:

صـورت أسـاليب البلاغة فكرة القصسيدة، و معانيها في مفارقة بين ماضي العرب، و حاضرهم، فجاء

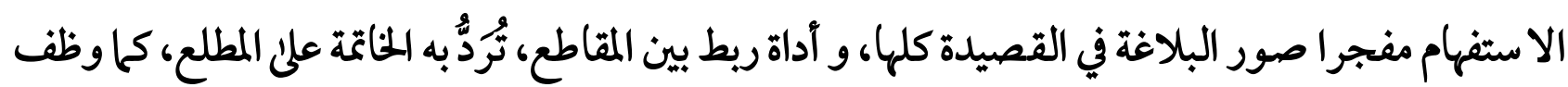
ال شاعر صور البيان كالتشبيه الذئ أبدع في تف صيل صورة المشبه به، ه ستق صيا جزئياتها، و الا ستعارة (تصريجية، و مكنية، وتبعية) و كثيرا ما يكثف التصوير بالتبعية، ملاحظا الترابط بين صورها، كما اعتمد على الكناية التي غالبا ما تبنى على المجاز، كما جدد في شكل القصيدة، و ابتكر صورا جديدة، و نادراً ما يلجاً إلى الإغراب في التصوير، كما وظف شبه كحال الاتصال بالاستئناف البيانى، جوابا عن سؤال مقدر، و قدراوح

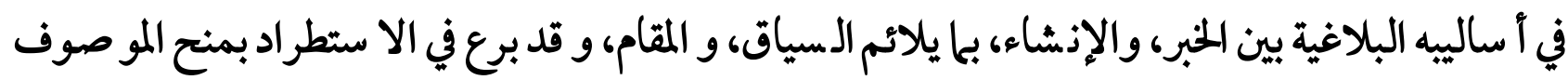
صفات متتابعة بلا عاطف، متأثراًاً سلوب القرآن الكريم، و آخيراً آكان لا ساليب (الإجمال والتف صيل، و و حسن التخلص، و المقابلة) و غيرها من أدوات الربط آثرها في إحكام بناء القصيدة، و دقة نسجها. د/ عبد العزيز أبو العزم عبد المقصود سليم

\section{An Extract}

In the Name of Allah, the Most Gracious, the Most Merciful Al-Muslimoun Poem by Mahmoud Hassan Ismail:

A Rhetorical Analysis Study by Dr .Abdulaziz Abul Azm ‘Abdul 


\section{Maqsoud Sleem}

This is an extract of the rhetorical analysis study of poet Mahmoud Hassan Ismail's "al-Muslimoun", or The Muslims, poem.

The study consisted of an introduction, a preamble, five research questions and a conclusion.

The intro highlighted the study's objectives and the reasons why it was conducted. The preamble summarized the poet's life and how it influenced his poetic style, as well as the context of the poem.

The opening research section deals with the artistic structure of the poem in four stanzas. The second section, titled Portraying the Muslims' State of Affairs Between Disorientation and Going Astray, addresses the rhetorical aspects of the first stanza.

Then follows section No. 3, which focuses on the rhetorical features of the second stanza under the title of Feeling Bewildered by the State of Muslims, Who Have The Quran.

The fourth research section, which bears the title of The Poet's Stance on his Nation's State, demonstrates the rhetorical aspects of the third stanza.

Finally, the fifth section, titled Between the Call for Fighting Corruption and The Fruitful Work, addresses the rhetorical sides of the fourth stanza.

The conclusion highlighted key findings, including:

How the rhetorical techniques in the poem clearly portrayed its main idea and meanings, showing the stark paradox between the Arabs' past and present states. The poet's use of the interrogative style disseminated rhetorical portrayals in the whole poem, and served as a means of strong, smooth connection between its parts from the very beginning to the end.

The poet also perfectly used eloquent styles like simile, which creatively detailed the state of vehicle. Likewise, he used different 
types of metaphor (explicit, implicit and auxiliary), and often intensified use of imagism, giving an attention to linking its manifestations (portrayals). He depended on trope-based metonymy as well

The poet created new poem forms, yet rarely resorted to weird portrayals. He efficiently took advantages of semi-completely connected styles for eloquently resuming poetic verses, using techniques answering supposed questions. He diversified his rhetoric styles, whether indicative or formative, in such a way that suited the context and situation.

Digression was brilliantly used by giving the described object several attributes with no coordinating conjunctions, reflecting an apparent influence of Quranic styles. Finally, other techniques like (summing up and detailing and chiasmus) greatly helped support the coherent buildup and delicate texture of the poem. 